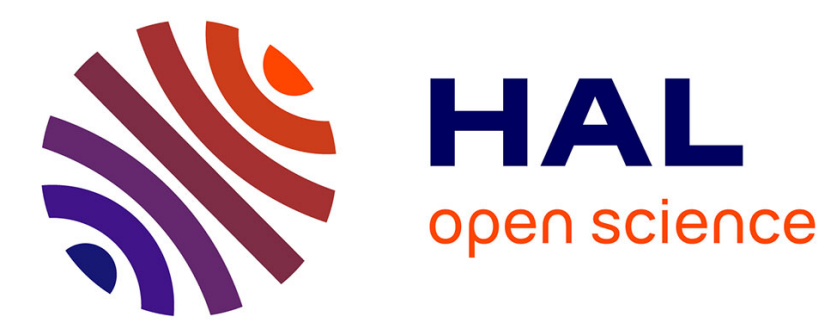

\title{
Institutional Environment and Bank Capital Ratios
}

Tammuz H Alraheb Ab, Christina Nicolas, Amine Tarazi

\section{To cite this version:}

Tammuz H Alraheb Ab, Christina Nicolas, Amine Tarazi. Institutional Environment and Bank Capital Ratios. 2018. hal-01475923v2

\section{HAL Id: hal-01475923 \\ https://hal-unilim.archives-ouvertes.fr/hal-01475923v2}

Preprint submitted on 27 Sep 2018

HAL is a multi-disciplinary open access archive for the deposit and dissemination of scientific research documents, whether they are published or not. The documents may come from teaching and research institutions in France or abroad, or from public or private research centers.
L'archive ouverte pluridisciplinaire HAL, est destinée au dépôt et à la diffusion de documents scientifiques de niveau recherche, publiés ou non, émanant des établissements d'enseignement et de recherche français ou étrangers, des laboratoires publics ou privés. 


\title{
Institutional Environment and Bank Capital Ratios
}

\author{
Tammuz H. ALRAHEB ${ }^{\text {ab }}$, Christina NICOLAS ${ }^{\text {ac }}$, Amine TARAZI ${ }^{\text {ad }}$ \\ ${ }^{a}$ Université de Limoges, LAPE, 5 rue Félix Eboué, 87031 Limoges Cedex, France.
}

This draft: 20 September 2018

Please do not quote without the permission of the authors.

\begin{abstract}
We investigate the influence of the institutional environment on bank capital ratios. Using a sample of 149 banks operating in the Middle East and North Africa region for the period 2004 to 2014, we find that, when stock markets have little presence, institutional variables significantly affect risk-weighted regulatory capital ratios but not leverage ratios. Conversely, when stock markets are more developed, only leverage ratios are influenced by institutional factors. Our results also indicate that institutional variables affect non-weighted equity-to-asset ratios of banks that are listed on a stock exchange. Our findings contribute to the bank capital structure literature and have important policy implications for developing countries.
\end{abstract}

JEL classification: G21, G28, G32

Keywords: Bank Capital Structure, Institutions, Bank Regulation

${ }^{b}$ Email: tammuz.al-raheb@unilim.fr (T.H. Alraheb).

${ }^{\mathrm{c}}$ Corresponding author. Email: christina.nicolas@unilim.fr, Phone: +33686179618, (C. Nicolas)

${ }^{d}$ Email: amine.tarazi@unilim.fr (A.Tarazi) 


\title{
Institutional Environment and Bank Capital Ratios
}

\begin{abstract}
We investigate the influence of the institutional environment on bank capital ratios. Using a sample of 149 banks operating in the Middle East and North Africa region for the period 2004 to 2014, we find that, when stock markets have little presence, institutional variables significantly affect risk-weighted regulatory capital ratios but not leverage ratios. Conversely, when stock markets are more developed, only leverage ratios are influenced by institutional factors. Our results also indicate that institutional variables affect non-weighted equity-to-asset ratios of banks listed on a stock exchange. Our findings contribute to the bank capital structure literature and have important policy implications for developing countries.
\end{abstract}

JEL classification: G21, G28, G32

Keywords: Bank Capital, Institutions, Bank Regulation 


\section{Introduction}

Research on bank capital structure has mostly focused on bank specific factors and market related fundamentals (Diamond \& Rajan 2000; Berger et al. 2008; Gropp \& Heider 2010; Harding et al. 2013). Another strand of the literature pioneered by Demirgüç-Kunt \& Maksimovic (1999) has stressed the importance of considering the legal and institutional framework affecting firms' capital structure decisions. In their paper, Demirgüç-Kunt \& Maksimovic (1999) posit that a significant part of long term debt variation can be explained by countries' institutional foundations. Nevertheless, the existing literature on the role played by institutions in explaining capital structure variation mainly includes studies of non-financial firms rather than financial ones (Booth et al. 2001; de Jong et al. 2008; Cho et al. 2014; Belkhir et al. 2016). In this paper, we build on these two strands of the literature to investigate whether institutional factors affect capital ratios of banking firms. We address the issue of whether the institutional environment plays a different role in enhancing either regulatory discipline or market discipline depending on the extent of the presence of stock markets. Regulatory and market discipline might not operate simultaneously as shown by Distinguin et al. (2013). We hence consider both regulatory capital ratios (imposed by regulators) and simple nonrisk weighted leverage ratios (internally set by the bank management) ${ }^{1}$. Our research is particularly relevant for developing countries and we focus on a world region whose underdeveloped institutions can be considered as a major obstacle to its economic and financial development: The Middle East and North Africa (MENA) region ${ }^{2}$. It is also a region where stock markets are either strongly present or almost inexistent. To our knowledge, our paper is the first attempt to specifically focus on the influence of

\footnotetext{
${ }^{1}$ Over our sample period (pre-Basel III) leverage ratios were not part of the regulatory framework.

2 The MENA region refers to the Middle East and North Africa region and consists of the following 21 countries: Algeria, Bahrain, Djibouti, Egypt, Iraq, Iran, Israel, Jordan, Kuwait, Lebanon, Libya, Malta, Morocco, Oman, Palestine, Qatar, Saudi Arabia, Syria, Tunisia, United Arab Emirates (UAE) and Yemen.
} 
institutional foundations on bank capital ratios, both regulatory and internally set by the bank management.

The MENA region is a fast-growing area which remains understudied when it comes to capital ratios of its financial institutions. This region suffers from ongoing political instability and lags behind the rest of the world in many dimensions. Particularly, institutions in the MENA region exhibit many deficiencies: widespread corruption, weak governance, limited creditors' rights, and a skeletal rule of law (World Bank 2014). The financial system is highly bank-based in most countries with banks assets reaching on average $130 \%$ of GDP (Saadaoui 2015). The region is characterized by underdeveloped financial markets (if existing) in most countries. In fact, high disparity in stock market development exists between countries of this region (for example, market development to GDP ratio was as high as 102\% in Qatar versus only 10\% in Egypt in end of 2016). The banking sector is highly concentrated in most countries of the region (with the three largest banks holding more than $65 \%$ of total banking assets on average) and barriers to entry are still high (Turk-Ariss 2009; Anzoategui et al. 2010). Thus, the MENA banking sector is far from being adequately developed, with the exception of Lebanon, Jordan, and the $\mathrm{GCC}^{3}$ countries (Creane et al. 2004). At the same time, most MENA banks showed resiliency during the global financial crisis of 2007-2008. In fact, this region was less affected by the financial turmoil compared to other parts of the world. Some researchers attributed this partial resiliency to a number of factors including the presence of a stable funding basis, prudent lending, and sound bank capitalization. Banks in the MENA region hold total regulatory capital ratios and tier 1 capital ratios significantly above international standards and Basel requirements ${ }^{4}$. This should, in principle, make them safer and more resilient to economic shocks. However, this might

\footnotetext{
${ }^{3}$ Gulf Cooperation Council - Bahrain, Kuwait, Oman, Qatar, Saudi Arabia, and United Arab Emirates. ${ }^{4}$ MENA Total capital adequacy ratio and Tier 1 capital ratio fluctuated on average between $18.5 \%$ and $21.7 \%$ and, $15 \%$ and $18.2 \%$, respectively, during the period 2004 to 2014. (Source: BankScope - Bureau van Dijk database)
} 
also make them too cautious in their intermediation role and their contribution to economic growth and development.

Throughout the last decade, the MENA region has experienced profound changes. What is prevalent however, is the fact that it still has underdeveloped institutions. A fragile rule of law and government ineffectiveness still prevail coupled with a weak and under-developed civil society. According to a recent World Bank survey (World Bank (2016)), the most important obstacles to development in the MENA region are the ongoing political instability and the high levels of corruption. Also, in an earlier World Bank report (World Bank (2014)), improving the rule of law, fighting corruption, improving accountability, stimulating government transparency and filling the gap between regulation and implementation are essential reforms that need to be conducted to improve the quality of institutions in the region.

The aim of this paper is to investigate the role played by institutional factors in determining capital ratios set by regulators and banks themselves. Fonseca \& González (2010) analyze the determinants of bank capital buffers while controlling for the role of institutions across a selection of world countries. They find that on the one hand, institutions improve market discipline and therefore increase bank capital ratios. On the other hand, good institutional quality reduces bank market power thus reducing bank incentives to hold high capital buffers. We extend the work of Fonseca and Gonzales (2010) by using various measures of formal institutional variables to specifically focus on whether the institutional environment affects bank capital ratios of banks operating in the MENA region. We go further by trying to test under what specific conditions institutional variables are significant determinants of bank capital ratios. We specifically focus on whether the effect of the institutional environment on bank capital ratios is conditional to the degree of development of stock markets.

We thus aim to contribute to the literature in the following ways. First, we focus on capital ratios of banking institutions whose capital decisions might substantially differ from non-financial firms. Since the literature has already documented the effect of 
institutional variables on non- financial firm capital holdings, we believe that bank capital ratios might be affected as well by the institutional framework prevailing in a country. We thus attempt to fill this gap in the literature by focusing on various aspects of the banking sector. In other words, we aim to find out in what specific conditions institutional variables might affect more or less capital ratios of banks. In our opinion, this is an important research area which might have important bank policy implications especially that the banking industry, unlike other sectors, is a heavily-regulated industry. We aim to provide evidence to regulators and policy-makers on whether bank capital ratios (regulatory and non-regulatory) are affected by formal institutions prevailing in a country and whether complying with more stringent regulatory requirements is easier to achieve in countries with a better institutional environment. To our knowledge, no other study has explicitly focused on the link between institutions and bank capital ratios. Second, we perform our study on the MENA region, which unlike other Western regions, remains understudied when it comes to bank capital and solvency ratios. Third, we consider both weighted regulatory capital ratios and un-weighted leverage ratios to investigate whether the quality of institutions affects banks' internal capital decisions regardless of regulation or more specifically to comply with regulatory constraints. Fourth, we focus on unravelling whether the degree of development of the stock market in a country affects the relationship between institutional variables and each of the capital adequacy ratio and the leverage ratio. We expect the effect of the institutional variables on capital ratios to be conditional to the stock market development since banks in countries with more developed stock markets might behave differently as they are exposed to higher market discipline. Capital market development could indeed be dependent on the institutional environment. Nevertheless, it is very uncommon to distinguish bank-based and market-based financial systems on these grounds. In marketbased systems, monitoring is expected to be achieved by the market, but this does not mean that bank-based systems are the result of a poorer institutional environment. Moreover, we focus in this paper on two different capital ratios: a regulatory one and a non-regulatory ratio. Market participants are known to monitor non-regulatory ratios more closely as such ratios are less prone to manipulation. Hence, market discipline 
might play a different role depending on the degree of stock market development and we expect the effect to be stronger for non-regulatory ratios.

We consider a sample of 149 banks from 14 MENA region countries covering the 2004-2014 period. Our findings indicate that institutional variables are significant in explaining risk-based capital adequacy ratios imposed by regulators. However, institutional variables (except for corruption) affect non-weighted equity-to-asset ratios (internally set capital) only for countries with developed stock markets. This effect is also more pronounced for banks listed on a stock exchange. We provide evidence that higher corruption and political instability levels are associated with lower capital adequacy ratios. Creditor' rights, however, negatively influence capital adequacy ratios. As for economic freedom and financial openness measures, the effect is positive.

The paper unfolds as follows. Section (2) presents an overview of the existing literature. Description of the sample, the variables used, and the empirical model are presented in section (3). Section (4) discusses the regression results and presents robustness tests. Finally, section (5) concludes. 


\section{Related Literature}

There is a substantive literature dedicated to the determinants of bank capital ratios. Brewer et al. (2008) argue that bank capital is significantly dependent on capital regulations. Moreover, the existence of deposit insurance creates moral hazard incentives which lead banks to choose high levels of leverage, thus maintaining low capital ratios while complying with regulation (Keeley 1990). However, this justification of bank capital levels does not explain the prevalence of bank capital buffers, i.e. higher levels than those required by regulations. In fact, many researchers emphasize that capital regulations are not binding and might not be significant determinants of bank capital levels (Flannery, 1994, and Diamond \& Rajan, 2000).

Perhaps one of the most important justifications behind holding high capital ratios is the fear of shocks which might drive a bank below capital requirements accompanied by high costs of adjusting back to the minimum threshold, leading to regulatory interference and eventually loss of reputation (Milne \& Whalley, 2001). Moreover, according to Brewer et al. (2008) and Harding et al. (2013), bank capital ratios seem high in countries where regulators have prompt sanction powers in dissolving financial institutions that fall below regulatory minimum. The latter authors also point out the importance of the franchise value in the choice of the optimal capital structure. From another perspective, Berger et al (1995) argue that banks' capital buffers are used to meet unexpected investment opportunities. Fonseca \& Gonzales (2007) analyze the determinants of bank capital buffers across a selection of world countries. They conclude that market discipline and market power positively and largely influence the level of capital buffers held by banks. Consequently, banks accumulate regulatory capital buffers mainly because of fear of adverse shocks, regulatory intervention, and market discipline.

Recently, a growing body of literature has focused on the role that institutions might play in determining firm capital structure. However, the findings regarding the influence of legal and institutional frameworks in explaining firms' funding choices are mixed. On the one hand, many studies find that firms operating in a better institutional 
environment have easier access to external funding associated with more favorable conditions (La Porta et al. 1997; Demirgüç-Kunt \& Maksimovic 1999; Booth et al. 2001; Giannetti 2003; Djankov et al. 2007; Qian \& Strahan 2007; González \& González 2008; Fan et al. 2012). A strong legal framework can help mitigate agency problems by reducing information asymmetries and when information is more readily available to investors, firms might start relying more on external rather internal funding. Hence, firms might hold less capital and more debt in countries with more developed institutions when considering the investors' or the supply point of view. On the other hand, supporters of the demand side view argue that lower debt prevails in markets with higher creditor rights. Cho et al. (2014) explain this finding using a large sample of 48 countries. They argue that managers in countries with high creditor protection prefer to limit debt usage to avoid losing control should financial distress prevail. This view is also supported by Rajan \& Zingales (1995) who argue that whenever manager rights are limited during bankruptcy and creditor rights are strong, managers tend to prefer equity over debt. Thus, no consensus has been reached in the literature regarding the effect of institutional quality on capital funding choices of non-financial firms ${ }^{5}$. In their paper, Flannery \& Oztekin (2012) go further by studying the role that institutions might play in capital structure adjustment speeds. They find that firms operating in countries with better institutions benefit from lower transaction costs which makes them adjust faster to their target capital structure.

Unlike studies on non-financial firms, we find no existing studies in the literature that specifically explore the link between institutional variables and bank capital holdings. Fonseca \& González (2010) analyze the determinants of bank capital buffers while controlling for the role of institutions across a selection of world countries. The

\footnotetext{
${ }^{5}$ For further studies covering corporate capital decisions, see: Deesomsak et al. (2004); Bancel \& Mittoo (2004); Gungoraydinoglu \& Öztekin (2011); de Jong et al. (2008); An et al. (2016).
} 
authors examine how institutions might alter the effect of market power and market discipline on capital holdings. For this purpose, they use the simple average of six institutional indicators as per Kaufman et al. (2001): control of corruption, government effectiveness, voice and accountability, regulatory quality, political stability, and the rule of law. They find that on the one hand, institutions improve market discipline and therefore increase bank capital ratios. On the other hand, good institutional quality reduces bank market power thus reducing bank incentives to hold high capital buffers.

A recent study by Haq et al. (2017) focused on studying the effect of informal institutions on bank capital structure. Using a large sample of banks in 79 countries, they employ the Hofstede cultural framework to show that national culture ${ }^{6}$ significantly affects capital structure of banks. More specifically, higher individualism, lower power distance, long-term orientation and indulgence positively affects bank capital ratios. They also show that this effect is much lower for large banks. They explain this by the fact that higher external monitoring and corporate governance in large banks opposes the effect of national culture.

In the MENA region, studies on bank capital have focused on bank-specific factors rather on the way in which banks interact with their macroeconomic and institutional environment. Murinde \& Yaseen (2006) investigate the dynamic capital-risk adjustment structure among MENA banks. They conclude that capital regulations are significant determinants of capital ratios. However, the authors point out that they do not affect capital levels, but they increase risk taking behaviors. Bougatef \& Mgadmi (2016) examine the role of prudential regulation on bank risk taking and capital holding in a selection of MENA banks. They find that regulatory pressure does not significantly affect neither risk nor capital ratios of MENA banks. The authors link this finding to

\footnotetext{
${ }^{6}$ National culture data is only available for 5 countries of our sample. Hence, data availability is once again an obstacle to the inclusion of data on informal institutions for the case of the MENA region.
} 
weaknesses in the institutions of those countries. This finding contradicts many studies on developing economies and more specifically the conclusion of Klomp \& Haan (2013) which stipulates that regulatory stringency reduces bank risk taking among banks in emerging countries.

Belkhir et al. (2016) study the role of institutions in determining corporate structure decisions of firms in the MENA region. Using data on 444 firms operating in the MENA region, they conclude that countries endowed with a better institutional framework (regulatory effectiveness and rule of law) rely relatively more on debt than equity. Corruption, on the contrary, has the opposite effect. Arwatani et al (2016) perform a study on corporate debt maturity of MENA banks. Their findings confirm a positive relationship between the use of long-term debt and the quality of institutions in each country. Since Gropp \& Heider (2010) have shown that the drivers of banks' capital structure are close to those of non-financial firms, institutional factors could also play an important role in explaining bank capital ratios in the MENA region. Hence, bank regulations might be playing a less important role in determining bank capital ratios (Flannery 1994; Diamond \& Rajan 2000; Allen et al. 2011) and institutional factors need to be taken into consideration. 


\section{Data, variables, and econometric specification}

In this section, before presenting our econometric approach and our variables, we describe our sample.

\subsection{Sample}

Our sample period ranges from 2004 to 2014 . We eliminate outliers at $1 \%$ and $99 \%$ of all variables ${ }^{7}$. After filtering, the sample includes 1307 bank-year observations, representing 149 banks (116 conventional and 33 Islamic banks) from 14 MENA region countries $^{8}$. The average number of observations per bank is 8 . The countries we consider are the following: Algeria, Bahrain, Egypt, Israel, Jordan, Kuwait, Lebanon, Malta, Morocco, Oman, Qatar, Tunisia, United Arab Emirates and Yemen. The sample includes state-owned and privately-owned banks and both listed and unlisted banks. For each bank, we use consolidated statements if data is available. Otherwise, we use unconsolidated data.

As for data sources, Yearly bank level data are extracted from the BankScope Bureau van Dijk database. Macroeconomic data is gathered from the Global Financial Development Database and the World Development Indicators of the World Bank. As for institutional data, we use different databases; the World Governance Indicators, the Doing Business Creditor Rights (World Bank), the Transparency International Organization and the World Heritage Foundation.

\footnotetext{
${ }^{7}$ We have cleaned all the variables including size by dropping all values lower than the 1 st and higher than the 99th percentiles in order to ensure that the sample we are working with is outlier-free. Size is also a variable for which incidental misreporting could occur.

${ }^{8}$ We begin by extracting from BankScope a sample of 305 commercial and Islamic banks operating in 21 MENA region countries. We eliminate 7 countries for which capital ratios or institutional data are not reported. We also drop Iran as it only includes Islamic banks and not both (Conventional and Islamic). After balancing our sample to obtain the same number of observations for all dependent variables (regulatory capital ratio is less reported compared to the simple equity to total assets ratio), we end up with 149 banks.
} 
Table (1) shows the distribution of banks in our sample by country and by type. Five countries in our sample do not have Islamic banks, while Algeria and Yemen do not have any listed banks, compared to Kuwait where all banks are listed. Egypt, Lebanon and UAE have the highest total number of banks. The final sample of banks represents $65 \%$ of the total bank assets of all the sample countries ${ }^{9}$.

[[insert table 1 here]]

\subsection{Econometric specification}

We adopt the following econometric model:

$C R i j t=\beta_{0}+\beta_{1} I N S T_{j t}+\beta_{2} B A N K_{i j t}+\beta_{3} O T H E R_{j t}+\beta_{4} S P E C S_{i j t}+C_{j}+C_{t}+\varepsilon_{i j t}$ [1]

where $\mathrm{CR}_{\mathrm{ijt}}$ stands for the capital ratio which represents either the total capital adequacy ratio (TCR) or the equity to total assets ratio (EQTA) of bank $\mathrm{i}$ in country $\mathrm{j}$ at time $\mathrm{t}$. $I N S T_{j t}$ is a set of variables accounting for the country's institutional framework. BANK $K_{i j t}$ represents a vector of variables used to control for bank specific characteristics. OTHER $R_{j t}$ is a vector of variables containing country level variables, other than institutional ones. SPECS $_{\mathrm{ijt}}$ includes a set of dummy variables specifying whether a bank is conventional or Islamic, Government owned or privately owned, and listed or unlisted. $\mathrm{C}_{\mathrm{j}}$ and $\mathrm{C}_{\mathrm{t}}$ control for country and time specific effects respectively to account for country level unobserved

\footnotetext{
${ }^{9}$ With respect to BankScope - Bureau van Dijk available data. The representativeness of our sample based on total assets is the following: Algeria (22\%), Bahrain (92\%), Egypt (98\%), Israel (42\%), Jordan (99\%), Kuwait (70\%), Lebanon (94\%), Malta (92\%), Morocco (57\%), Oman (93\%), Qatar (52\%), Tunisia (16\%), United Arab Emirates (62\%) and Yemen (69\%).
} 
heterogeneity or some other global trend in banking behavior. $\varepsilon_{i j t}$ are the error terms which we cluster at the bank level."

To go further in our analysis, we add to model [1] an interaction term between institutional variables and the type of the bank (INST*Type). The variables Type is then replaced with a dummy accounting for bank size (Large), a dummy which controls for whether the bank is government-owned (Gov) or not, a dummy for Islamic banks (Islamic), or a dummy to proxy for whether the bank is listed on a stock exchange or not (Listed). Model [1] becomes:

$$
\begin{aligned}
& C R i j t=\beta_{0}+\beta_{1} I N S T_{j t}+\beta_{2} \text { BANK }_{i j t}+\beta_{3} \text { OTHER }_{j t}+\beta_{4} S P E C S_{i j t}+\beta_{5} \text { INST }^{*} \text { Type }_{i j t}+ \\
& C_{j+}+C_{t}+\varepsilon_{i j t}
\end{aligned}
$$

Regarding the estimation method, although the fixed effects within estimator would resolve the issue of correlation between the unobserved individual effects and the explanatory variables, by subtracting individuals means from variables, all time-invariant variables would be dropped. To deal with this issue, we use the Hausman Taylor (1981) instrumental variable estimator approach by which some of the regressors are allowed to correlate with the individual effects (HT). We adopt the HT methodology because our main variables, the institutional variables, are almost time-invariant. Furthermore, HT deals with possible endogeneity induced by individual bank specific effects and allows us to control for cross country variations while at the same time allowing for the incorporation of time-invariant variables. We use the Hausman test to verify that using the HT model is the most appropriate in the case of our data. The Hausman test does not reject the null that the HT estimator is equivalent to the fixed effects estimator. The fixed effects estimator is thus consistent but less efficient, suggesting the use of HT as consistent and more efficient estimator.

The Hausman-Taylor estimator deals with the correlation issue between some regressors and the individual effects. However, using lagged variables, addresses the 
issue of endogeneity, that is, the correlation between the regressor and the time-varying idiosyncratic error term. To mitigate possible endogeneity issues, we use the first lag of all bank level independent variables. Thus, size, return on assets, and risk measures are included in the regression at their lagged values.

\subsection{Definition of variables}

\subsubsection{Dependent variables}

The MENA region has underdeveloped capital markets in some countries, and even no capital markets in others. For this reason, we focus in this study on book capital ratios. Our main dependent variable is the total regulatory capital ratio (TCR). This total capital adequacy ratio as per Basel rules is the ratio of Tier 1 and Tier 2 capital (hybrid capital, subordinated debt, reserves for loan losses, and valuation reserves) to total risk weighted assets and off-balance sheet weighted risks. We also consider the equity to total assets ratio (EQTA) which is non-risk weighted and therefore reflects the internal bank capital holding decisions while TCR reflects the regulatory influenced capital.

\subsubsection{Independent variables}

\subsubsection{Main variables}

First, we use an indicator of political stability (PS) from the World Governance Indicators of the World Bank ${ }^{10}$. Political instability is one of the major obstacles facing countries in the MENA region and the region's average is one of the lowest in the world. This indicator is scaled from -2.5 to +2.5 with higher values indicating higher political stability. On the one hand, banks in politically unstable regions might boost their capital ratios as a mean of gaining trust of investors/clients. Hence, attracting depositors might

\footnotetext{
${ }^{10}$ Our study includes a country-level indicator of political stability. For other insights on political patronage and the role of political connections in banking, see studies such as the ones by Fraser et al. (2006) and Bliss and Gul (2012).
} 
be a major explanation of high capital holdings by banks in fragile political environments. On the other hand, banks operating in fragile environments might be reluctant to raise equity and might prefer to maintain low capital ratios to prevent any potential loss of control should the country's political situation get worse. Considering the prevalence of high levels of political instability in the region we consider, we expect a positive association between political stability and bank capital ratios.

We use two indicators of creditors' rights form the Doing Business database; resolving insolvency and getting credit. The Resolving Insolvency (RI) variable includes the time, costs, outcome of insolvency, liquidation, and reorganization proceedings. The Getting Credit (GC) indicator measures the ease of obtaining credit as well as the ease of accessing credit information (existence of credit bureaus and credit registries for example). These two indicators are scaled from 0 to 100 with higher scores indicating higher levels of creditors' rights. Results concerning the effect of creditors' rights on capital ratios have been mixed in the literature. As mentioned previously, high creditor rights might lead managers to limit debt usage to avoid losing control should financial distress prevail (Rajan \& Zingales 1995; Cho et. al 2014). At the same time, higher creditor rights results in less information asymmetry and easier access to external funding. Thus, credit would be available at more favorable conditions. Hence, firms in this case might prefer holding more debt than equity (La Porta et al. 1997; González \& González 2008). On the basis of the above, we expect measures of creditors' rights to have negative influence on capital ratios of banks operating in the MENA region.

We also use indicators of economic freedom from the World Heritage Foundation. The aggregate index, the Economics Freedom (EF) index ${ }^{11}$, measures the extent to which individuals can control freely their property or labor. In other words, this

\footnotetext{
11 The Economic Freedom Index is computed as the simple average of the following ten sub-indicators: Property rights, Freedom from corruption, Fiscal Freedom, Government Spending, Business Freedom, Labor Freedom, Monetary Freedom, Trade Freedom, Investment Freedom, and Financial Freedom.
} 
indicator assesses to what extent capital, labor, and goods can move freely in a given economy. We build an indicator that we call Financial Openness (FO) to focus closer on the potential role that can be attributed to trade and financial freedom. Trade freedom measures the ease of importing and exporting goods and services. Financial freedom captures the independence of the financial sector from government control as well as bank efficiency. This indicator is also scaled from 0 (lowest freedom) to 100 (highest freedom). We expect a positive effect of EF and FO indexes on bank capital ratios. Broader exposure to international markets as well as more financial freedom and thus higher competition pushes banks to hold higher capital ratios possibly to signal stronger financial conditions aiming at attracting more funds.

We include the corruption perception index (CPI) which represents the perceived level of corruption in a country's public sector ${ }^{12}$. CPI is calculated on a scale of 0 (severely corrupt) to 100 (no corruption). Corruption is a widespread phenomenon which is much more prevalent in underdeveloped and developing economies. It's effect on economic growth has been widely studied. Many studies confirm the detrimental role of corruption on growth. Other studies, however, such as Shleifer \& Vishny (1993); Mo (2001); Wei (2000), find that it can have a beneficial effect on economic growth by promoting a better allocation of resources. One way is paying bribes to evade inefficient rules for example (Huntington 1970; Acemoglu \& Verdier 2000). In the MENA region, a large part of bank capital is held by government officials and political parties. Hence, corruption might lead banks to abide less by capital regulations as political power and bribery can be used to circumvent such regulations. Hence, we expect a positive sign of the CPI on bank capital ratios.

\footnotetext{
12 We concentrate on country-level corruption levels to be coherent with other institutional variables. For bank-level corruption studies, such as corruption in lending, see studies such as Houston et al. (2011), Barry et al. (2016), inter alia.
} 
In addition, we perform a principle component analysis and use the first factor to produce a broader index of our institutional factors (IFI) excluding measures of creditors' rights for which we construct a separate index (CRT). IFI is thus the first principal component of: Political stability (PS), financial openness (FO), economic freedom (EF), and corruption (CPI). Factor loadings are as follows: 0.68 for PS, 0.92 for EF, 0.67 for FO, 0.89 for CPI. CRT is the principal component of two indexes: getting credit (GCREDIT) and resolving insolvency (RI). Factor loadings are 0.67 for both subindexes.

\subsubsection{Control variables}

We include several bank specific variables widely used in studies on capital ratios. We proxy bank size by introducing the logarithm of total bank total assets (SIZE). SIZE is expected to negatively influence capital ratios as larger banks tend to hold less capital consistent with the "too big to fail hypothesis" (Brewer et al. 2008; Kleff \& Weber 2008; Fonseca \& González 2010). These banks might also benefit from economies of scale, broader asset diversification, and an ease of obtaining equity on a short notice which makes them subject to lower financial distress costs (Rime 2001; Berger et al. 2008). Larger banks are thus less motivated to hold higher capital ratios, consistent with the capital trade-off theory in which deadweight bankruptcy (which are lower for larger banks) is traded off against tax saving incentives of holding more debt.

The Return on Assets (ROA) ratio is used to proxy bank profitability. It is calculated as the ratio of a bank's net income to its average assets. Profitability is expected to boost capital ratios as more profitable banks tend to have higher capital to assets ratio by injecting their retained earnings into capital, consistent with the pecking order theory (Gropp and Heider 2010; Brewer et al 2008). This would especially be expected in the case of the equity to assets non-risk-weighted ratio. This view is especially expected to hold in a region with underdeveloped financial markets such as the MENA region. At the same time, we can also expect more profitable banks to hold lower capital ratios because higher profitability is in line with a reduction in funding costs 
(Berger et al., 2017). More profitable banks are expected to face lower financial distress and interest tax shields appear to them more valuable. Hence, according to the taxbankruptcy trade-off theory of capital, more profitable banks will hold lower capital ratios. Moreover, the agency-trade-off theory of capital stipulates that in such firms where cash flow is higher, debt will have a higher disciplinary effect (on managers). Hence, to mitigate agency problems, banks are the motivated to hold more leverage (Jensen 1986). All in all, the impact of profitability measured by the ROA on capital holdings is uncertain.

To account for bank risk, we use the logarithm of the ZSCORE. The ZSCORE is widely used as a proxy for bank risk in the literature (Boyd et al. 2007; Laeven \& Levine; 2009, Fu, et al.; 2014). It measures the probability of bank failure. It is calculated as follows:

$$
\mathrm{ZSCORE}=(\mathrm{ROA}+\mathrm{TCR}) / \sigma(\mathrm{ROA})
$$

where ROA is the return on assets ratio, TCR is the total capital adequacy ratio, and $\sigma(\mathrm{ROA})$ is the standard deviation of the ROA. We use a moving mean and standard deviation estimates with a three-year rolling window. Higher levels of the ZSCORE are associated with higher levels of stability since this ratio is the inverse of the probability of insolvency. We use the logarithm of the ZSCORE. Findings on the effect of risk on capital ratios have been mixed in the literature. Many studies found a positive effect of risk on capital as the latter serves as a cushion for potential losses hence banks tend to hold more capital when they are riskier (Shrieves \& Dahl 1992; Nier \& Baumann 2006; Gropp \& Heider 2010; Berger et al. 2008). However, from an opposite perspective, the relationship between capital and risk might be negative since banks who are risk-takers also prefer a riskier capital position (hence lower capital ratios) (Fonseca \& González 2010).

To account for a country's regulatory framework, we include an indicator of regulatory capital stringency (REG). This indicator is manually constructed based on the 
Barth et al. World Bank Regulation and Supervisory Database ${ }^{13}$ (Barth et al. 2004, Barth et al 2008, and Barth et al. 2013). This indicator ranges from 0 to 3 with one point given to every risk type covered by the country's regulatory jurisdiction (credit risk, market risk, and operational risk). The higher the indicator, the stricter the capital regulations. The sign of this variable is expected to be positive since banks will be more constrained to hold higher capital ratios in countries where regulations on capital are tighter and cover more aspects of banking risk. At the same time, countries in the region we consider hold capital ratios much higher than what Basel agreements stipulate. Hence, regulation stringency might not be a significant determinant of capital ratios.

We also control for whether the country has an implicit or explicit deposit insurance (DEP_INS) scheme. We use a dummy variable which takes the value of 1 for an explicit deposit insurance system and 0 for an implicit deposit insurance scheme. We expect banks operating in countries with explicit deposit insurance to be more leveraged. Deposit insurance creates moral hazard incentives which lead banks to choose high levels of leverage, thus maintaining low capital ratios (Keeley 1990). Alternatively, implicit deposit insurance could also mean that depositors would not suffer from any losses if banks are most likely to be bailed out. Hence, banks could also have incentives to hold less capital in the absence of explicit insurance. Also, in the presence of explicit deposit insurance, if banks can actually fail and if depositors are effectively not reimbursed above the limit (credibility of non-insurance above the limit) banks will have incentives to take less risk than under implicit insurance. Hence the coefficient of this variable could also be significantly negative.

\footnotetext{
${ }^{13}$ We use the three versions available of this database $(2003,2007$, and 2012). We consider the variables constant between the 3 versions. In other words, years 2004 to 2006 take the values of the 2003 survey, years 2008 to 2011 take the values of the 2007 survey, and years 2013 and 2014 takes the values of the 2012 most recent survey.
} 
To proxy for bank concentration, we use the Herfindhal-Hirschman index (HHI). The HHI is widely used in the literature to proxy for concentration. We base our HHI on total assets. Our indicator (CONC) is thus calculated as the sum of the squared weights of banks assets for every country and in each year. The higher the index, the higher the concentration. In countries with high bank concentration, banks with higher market power would hold more capital to preserve their charter value. At the same time, a higher franchise value might be considered as a source of extra income, which reduces the need to hold higher capital ratios to hedge against unexpected losses (Fonseca \& Gonzales 2010).

We consider GDP Growth (GDP) to examine the possible impact of the business cycle on capital ratios. Many studies document a negative relationship between regulatory capital ratios and the business cycle (Ayuso et al. 2004; Shim 2013). As per these authors, banks tend to decrease (increase) their capital holding during economic upturns (downturns). At the same time, banks might prefer to increase capital ratios during economic booms to benefit from potential investment opportunities (Berger 1995).

Finally, we include three dummy variables (Islamic, Gov, and Listed) to capture whether a bank is conventional or Islamic, Government-owned or privately-owned, and listed or unlisted on a stock exchange respectively. We aim to test how a bank's internally-set (leverage ratio) and externally-set capital ratios (regulatory ratio) are influenced by these different characteristics. 


\section{Results}

\subsection{Descriptive statistics}

Table (2) presents the descriptive statistics of the sample used in this study. Mean TCR and EQTA are respectively at $18.6 \%$ and $13.1 \%$. MENA TCR average is actually much higher than international standards and Basel requirements. EQTA exhibits large cross-country variations with a minimum of $3 \%$ in Malta and a maximum of $72.7 \%$ in UAE. The banking sector is also on average highly concentrated with a sample mean value of 0.17 on the Herfindahl index. Most concentrated banking sectors are in Qatar and Bahrain. Bahrain also has the largest banks by bank size among all countries in our sample. The ZSCORE averages at 1.9 for the region with the highest score recorded in Lebanon at 4.3. As for profitability, the mean ROA in our sample is at $1.38 \%$ which is much higher than a global world average of $0.89 \%$. Based on these descriptive statistics, banks in the MENA region can be characterized as highly capitalized, highly concentrated and relatively profitable.

[[insert table 2 here]]

Table (3) shows the evolution of TCR and EQTA averages by country and through time. TCR fluctuated between $17.9 \%$ and $21.5 \%$ during our sample period (2004 to 2014). On the region level, EQTA was as low as $11.6 \%$ in 2004 reaching a high of 14.3\% in 2011. In 2014, TCR is the highest in Algeria at 36\% and the lowest in Morocco at 13.6\%. For EQTA, in 2014, Israel has the lowest level (5.9\%). Algeria exhibited the highest EQTA in 2014 (32.2\%), followed by Bahrain (25.6\%). It is also worth pointing out the fact that all countries in the MENA region maintained capital ratios much higher than what Basel agreements stipulate. 
[[insert table 3 here]]

Table (4) presents the distribution of our institutional variables by country. Institutional quality varies greatly between countries in our sample. On a scale of -2.5 to +2.5 , PS ranges between -2.5 and 1.39 and averages as low as -0.44 . The mean for the region is at -0.44 which shows high political instability for the region as a whole. FO and EF indicators both average at 64/100 approximately. Corruption levels have high disparity between countries, attaining as low as $15 / 100$ to as high as $77 / 100$ with a total sample average of $45 / 100$.

[[insert table 4 here]]

Table (5) displays the correlation matrix between all variables employed. No major correlation issues exist between our variables except for institutional variables which exhibit high correlation coefficients. To further test whether including all institutional variables simultaneously in the regression is viable, we run the VIF (Variance Inflation Factor) test following Besley et. al (1980). We obtain values higher than 5 which suggests that including all institutional variables at the same time is not viable and associated with multicollinearity issues that might lead to misleading results. Hence, we include one institutional variable at a time when running our regressions. Moreover, we use the principal component indicators (IFI and CRT) that we have computed to assess the global impact of all institutional variables simultaneously.

[[insert table 5 here]] 


\subsection{Mean tests}

Before running our model, we run mean tests on our sample. We perform mean tests on TCR to check whether we obtain significant mean TCR differences between countries with high institutional development compared to countries with low institutional development. Table (6) shows the results. Findings indicate that TCR has significantly higher average values in environments endowed with higher Political stability (PS), economic freedom (EF), and corruption (CPI)). On the contrary, in countries where higher creditors' rights prevail (GC and RI), total capital adequacy ratios seem to be significantly lower.

[[insert table 6 here]]

\subsection{Regressions results}

\subsubsection{Main regression results}

Table (7) reports the main regression results. Each institutional variable is separately introduced in the regressions due to high correlation among these variables. Panel A (columns 1 to 7) reports the results for TCR while Panel B (columns 8 to 14) represents the results for EQTA. All institutional variables reported are significant in explaining the total capital ratio (TCR). TCR is positively affected by political stability. Banks in politically stable countries tend to hold higher risk-weighted capital ratios. Consistent with (González \& González 2008) who show that stronger creditor rights cause firms to be more leveraged, we find that creditor rights (higher GC and RI) have a significant negative effect on TCR. When a client defaults on his debt, if the bank can more easily retrieve the amount of the loan, it will hold less capital as a cushion. Hence, banks hold less capital in countries where resolving insolvency is easier. Moreover, creditor rights also measure the ease of liquidation and reorganization. A bank might 
prefer holding lower capital ratios when stricter liquidation rules apply. La Porta et al., (1997) argue that firms are likely to be more leveraged in the presence of more favorable creditor rights because in such a context credit would be available in more favorable conditions. Higher economic and financial freedom indexes are significantly associated with higher values of TCR. Broader exposure to international markets and thus higher competition to attract funds pushes banks to hold higher capital levels possibly to signal stronger financial conditions. CPI is positively significant at the $1 \%$ level. Less corruption leads banks to hold more capital, a result which is consistent with the findings of Belkhir et al., (2016) regarding MENA non-financial firms whose leverage levels are found to be positively linked with corruption. Results using principal component analysis are presented in columns 7 and 14 of Table (7). IFI exhibits a positive significant sign on TCR. Banks operating in countries endowed with better institutional environments (higher political stability, higher economic freedom and financial openness and lower corruption) tend to hold higher regulatory capital ratios. Consistent with its sub-indexes, CRT negatively affects TCR as well and is significant at the $1 \%$ level.

Among control variables, we find that size and profitability are negatively significant for both capital ratios. Large banks tend to hold less capital, consistent with the view that they can raise capital more quickly should an adverse situation occur. This is also in line with Berger et al. (2008), Fonseca and Gonzales (2010) and DemirgüçKunt, Kane, \& Laeven, (2014) who posit that large banks benefit from government bailouts and other guarantees, have higher economies of scale and better risk management and therefore can hold less capital than smaller banks. More profitable banks seem to hold lower TCR consistent with the tax-bankruptcy trade-off theory and the agency trade off theory of capital. Risk and concentration are however insignificant in explaining both capital ratios. Capital ratios of banks in the MENA region do not seem be affected neither by the risk of default of the bank nor by its market power. In the literature, findings on the effect of risk on capital ratios have been mixed. Many studies found a positive effect of risk on capital as the latter serves as a cushion for potential losses hence banks tend to hold more capital when they are riskier (Shrieves \& Dahl 1992; Nier \& Baumann 2006; Gropp \& Heider 2010; Berger et al. 2008). However, from 
opposite perspective, the relationship between capital and risk might be negative since banks who are risk-takers also prefer a riskier capital position (hence lower capital ratios) (Fonseca \& González 2010). We observe no significance of risk in the case of our data suggesting that both opposing hypothesis on risk might be affecting capital ratios whereby the net effect is neutral. GDP exhibits an insignificant coefficient as well meaning that there seems to be no cyclical or counter cyclical behavior of capital ratios for banks in the MENA region. Capital adequacy ratio coverage (REG), which measures the stringency of capital regulations is also insignificant. Banks do not seem to be affected by the country's regulatory framework when choosing their capital ratios which are already much higher than minimal requirements. This is in line with (Bougatef \& Mgadmi 2016; Awdeh et al. 2011) who show that regulations do not affect capital holdings of banks operating in the MENA region. This is especially relevant considering the fact that TCR values for all countries in the region are much higher than what Basel agreements impose.

Furthermore, the dummy variables we include provide evidence that government owned banks as well as listed banks hold higher TCR than privately owned banks and unlisted banks, respectively. Listed banks are indeed expected to hold more capital because of easier access but also because they are subject to market discipline and hence "pushed" by the market to hold higher capital ratios. Governments of underdeveloped and emerging countries such as the ones in the MENA region might have high pre-set levels of capital ratios and lower levels of flexibility when it comes to going below these set levels (regulatory and simple equity ratios). In addition, those banks might worry less about the opportunity cost of capital (unlike private banks), the fact which can also explain the positive sign of the government ownership dummy variable.

Unlike TCR, EQTA is not affected by institutional variables (except for CPI and $\mathrm{GC}$ which have a marginal positive significance). Institutional factors hence appear to affect the regulatory constraint related to capital without playing a major role in determining the capital targets that banks set internally regardless of regulation. Concerning control variables, we find that profitability is positively significant at the $1 \%$ 
level. Banks with higher retained earnings are expected to hold higher equity to total assets ratio. As for TCR, size shows a significant negative sign on EQTA, implying that large banks maintain lower EQTA levels. The dummy variable Gov is also positively significant with a higher significance compared to results for TCR. In the MENA region, government-owned banks maintain higher capital ratios compared to privately-owned banks.

[[insert table 7 here]]

\subsubsection{Further investigations}

\subsubsection{Stock market development}

To go further in our investigation, we divide our sample into two sub-samples of developed stock markets (above the median) versus less developed stock markets (below the median) using the market capitalization to GDP indicator (MK_GDP) of the World Bank. For our sample, the MK_GDP median is at $48.3 \%$. We split our sample according to the degree of development of the stock market because we expect market discipline to play a stronger role in influencing leverage ratios where stock markets have a deeper presence. In other words, we expect the effect of institutional variables on capital ratios to be conditional on the degree of stock market development since banks in countries with more developed stock markets might behave differently as they are exposed to higher market discipline. The effect might also be different depending on whether we consider regulatory (risk-weighted) or non-regulatory capital ratios (non-risk-weighted). Market participants are known to monitor non-weighted capital ratios more closely as such ratios are less prone to manipulation than risk-weighted ratios

The results of stock market development sub-samples are presented in tables (8) and (9). Table (8) shows the results for countries where stock markets are less developed while table (9) includes countries with more developed stock markets. For countries endowed with lower levels of stock market development, all institutional variables with 
the exception of political stability are significant for regulatory capital. Our results confirm our expectations that institutional variables significantly influence TCR for less developed stock markets whereas EQTA is not affected for most variables. Conversely, when markets are more developed, institutional variables are only significant in explaining leverage ratios (EQTA). In other words, when the stock market is developed, a better institutional environment positively affects banks' internally set capital possibly because this capital serves as a signal of better soundness to the market. More specifically, market-based fundamentals in this case care much more about simple leverage ratio rather than risk weighted ratio. While when the market is weakly present, a well-developed institutional environment seems essential to ensure the effectiveness of bank capital regulations.

We perform further analysis to study whether the effect of the institutional environment in developed versus underdeveloped stock markets differs with the type of bank considered, that is, large or small, listed or non-listed, and conventional or Islamic (Tables 10a,10b, and 10c). Our results show that when the stock market is relatively more developed, such results are robust for large banks, listed banks, and Islamic banks. For countries with weaker presence of stock markets, institutional variables are more effective for large and conventional banks. While for Islamic banks, the institutional environment (except for PS) does not seem to affect their internally set capital (EQTA) nor the regulatory capital (TCR). In fact, Islamic banks have their own agendas and capital regulations are not much relevant for such banks. Leverage ratios of listed banks also seem to be more influenced by the institutional environment since market discipline is also much more relevant in the case of listed banks compared to non-listed banks. In the following sub section, we introduce interaction terms in order to further examine whether the type of bank influences the relationship between institutional variables and bank capital ratios. 


\section{[[insert table 8here]]}

[[insert table 9 here]]

[[insert table 10a here]]

[[insert table $10 \mathrm{~b}$ here]]

[[insert table 10c here]]

\subsubsection{Bank characteristics}

For deeper insights on whether the effect of the institutional environment is conditional to the type of the bank, we proceed in estimating model [2]. First, we interact institutional indicators with a dummy that accounts for size (INST*Large). Large takes the value of 1 if the bank is large and zero if the bank considered is small to test whether large banks are affected differently. We consider a bank as large if its total assets are above one billion USD and/or if it belongs to the top 5 banks in each of our countries. Tables 11 shows the results for bank size. Our results show that the effect of all the institutional variables (except PS) on TCR is much more pronounced for Large banks compared to smaller ones.

[[insert table 11 here]]

Second, to assess whether the effect of institutional variables is conditional to whether the bank is government-owned or not, we interact institutional indicators with a dummy that accounts for Government ownership (INST*Gov). We consider a bank government-owned if more than $25 \%$ of its shares are held by the government. Results are displayed in table 12. Results in Table [12] indicate that no difference exists between 
the effect of institutional variables on government-owned and non-government owned banks except for the indicator of corruption. The higher the corruption in a given economy, the lower capital ratios of banks are, especially for non-government-owned banks.

[[insert table 12 here]]

Third, we replace Type by Islamic to test whether Islamic versus conventional banks are affected differently. Islamic takes the value of 1 for an Islamic bank and 0 for a conventional bank. Table 13 reports the results. Results show that the negative effect of creditors' rights on TCR is more pronounced for conventional banks. Measures of creditors' rights are less likely to affect capital ratios of Islamic banks possibly because using capital to hedge against risk is less relevant for such banks.

[[insert table 13 here]]

Finally, we test whether the behavior of listed and unlisted banks differ in this scope. INST*Type becomes INST*Listed in this regression. Listed takes the value of 1 for a bank listed on a stock exchange and zero if the bank is not listed on any stock exchange. Results in table 14 indicate that institutional variables affect TCRs of nonlisted banks without having any effect on listed banks' TCRs. However, and as expected, institutional variables (except for political stability) influence EQTA of listed banks only. It seems that institutional variables increase market discipline which is much more relevant for banks listed on a stock exchange compared to non-listed ones. Moreover, market participants care more about the leverage ratios than regulatory ratios, one major 
explanation behind which our results are more pronounced for EQTA of listed banks specifically.

[[insert table 14 here]]

\subsection{Robustness tests}

We run several tests to check for the robustness of our results. We start by using different measures of capital ratios as dependent variables. First, we use the Tier1 capital ratio as dependent variable. Tier1 is defined as the core equity capital of a bank to its risk-weighted assets, it is thus the "pure" version of capital and may reflect better the financial strength of a bank from the regulator's point of view. Our regression results confirm our findings for TCR whereby all institutional variables are positively significant in explaining Tier1 ratio except for creditor's rights which affect Tier1 negatively (Appendix, Table 1). Second, we replace TCR by capital buffers (KBUFF). Capital buffer is defined as the difference between the total regulatory capital ratio and the minimum required by capital regulation in each country. Although some differences exist between countries of our sample in terms of regulatory minima levels, the results of our main variables of interest, the institutional variables, are very similar to of the ones obtained with TCR (Appendix, Table 2). Third, we estimate our model in a dynamic setting using the generalized method of moments (GMM) developed by Arellano and Bond (1991). We control for the endogeneity of bank-level and institutional variables by using two to four lags of the variables themselves as instruments in our model. Results are presented in Table (3) of the Appendix. Findings confirm the robustness of the results obtained with the Hausman-Taylor methodology in our main regression. Finally, to make sure our results are not driven by specific countries, we exclude the Gulf Cooperation Council (GCC) countries (Bahrain, Kuwait, Oman, Qatar, and the UAE), Malta and Israel from the regressions as these countries are endowed with better financial and institutional 
foundations compared to others in the sample. We also observe no major changes compared to our main regression results. We can thus conclude that our results are not driven by these excluded countries (Appendix, Table 4). 


\section{Summary and concluding remarks}

This paper studies the influence of institutional factors on bank capital structure using panel data on 149 banks operating in the MENA region for the period 2004 to 2014 . We contribute to the increasing number of studies pioneered by Demirguc-Kunt and Maksimovic (1999) on the importance of accounting for country level institutional characteristics when studying different aspects of the financial sector.

For this purpose, we use two measures of bank capital structure; the risk-weighted capital ratio imposed by regulators, which accounts for the level of risk in banks' asset portfolios, and a measure of leverage which is a non-risk weighted simple equity-to-asset ratio set by bank managers internally. Our results indicate that banks in countries with higher political stability, more pronounced economic and financial freedom, as well as lower levels of corruption hold more regulatory capital. Creditors' rights, on the contrary, have the opposite effect. A closer look shows that such effects only hold in countries where stock markets are weakly developed. Furthermore, the influence of institutional factors in less developed stock markets is more pronounced for large and conventional banks compared to smaller and Islamic banks respectively.

Conversely, when stock markets are more present only non-weighted capital ratios are affected by institutional factors. Likewise, our results also indicate that institutional variables influence EQTA of listed banks only. Hence, institutional factors appear to play a stronger role regarding market discipline than regulatory discipline in countries with developed stock markets but when stock markets are weakly present they are effective in enhancing regulatory discipline.

Our results have several policy implications. Institutional quality must not be assessed independently of the degree of presence of stock markets when studying capital structures of banks operating in developing countries and in the MENA region more specifically. The region suffers from several institutional deficiencies which seem to have implications on many sectors including the financial and banking sector. According to our results banks operating in countries with better institutional environments hold higher 
bank capital ratios and are therefore expected to be safer than banks in countries with less developed institutions. However, the degree of development of stock markets also plays an important role by influencing the channel through which banks are monitored. Our results show that the quality of the institutional environment differently affects riskweighted regulatory capital and non-weighted equity ratios depending on whether the stock market is more or less developed. According to our findings, institutional foundations seem to play a significant role in determining regulatory capital ratios in countries with less developed stock markets. Thus, institutional quality should not be disregarded especially in countries where the stock market is relatively underdeveloped. Such quality appears to be an important value to ensure better and more effective compliance to regulation when stock markets are weakly present. However, when stock markets are more developed institutional quality adds less in terms of regulatory scrutiny and compliance possibly because the market has already imposed some discipline. Moreover, from a financial markets' perspective, leverage is much more relevant as a signal of soundness to the market rather than the regulatory risk-weighted capital ratio. This might also be a major reason why institutional variables affect leverage ratios much more in countries with relatively developed stock markets.

Hence, promoting institutional development can be considered of vital importance not only to a country's economic and social development but also to ensure financial stability and resilience to local or global shocks. Finally, our results indicate that complying with more stringent international regulatory standards is possibly easier to achieve in countries with a better institutional environment. Also, in weaker institutional environments, regulators and supervisors need to monitor banks more closely and make more efforts in that direction. 


\section{References}

Acemoglu, D. \& Verdier, T., 2000. The choice between market failures and corruption. American Economic Review, 90(1), pp.194-211.

Aggarwal, R. \& Jacques, K.T., 2001. The impact of FDICIA and prompt corrective action on bank capital and risk: Estimates using a simultaneous equations model. Journal of Banking \& Finance, 25(6), pp.1139-1160.

Al-tamimi, H.A.H. \& Jellali, N., 2013. The effects of ownership structure and competition on risk-taking behavior: Evidence from UAE coneventional and Islamic banks. The International Journal of Business and Finance Research, 7(2), pp.115124.

Allen, F., Carletti, E. \& Marquez, R., 2011. Credit market competition and capital regulation. Review of Financial Studies, 24(4), pp.983-1018.

An, Z., Li, D. \& Yu, J., 2016. Earnings management, capital structure, and the role of institutional environments. Journal of Banking \& Finance, 68, pp.131-152. Available at: http://dx.doi.org/10.1016/j.jbankfin.2016.02.007.

Anzoategui, D., Martinez Peria, M.S. \& Rocha, R.R., 2010. Bank Competition in the Middle East and Northern Africa Region. Review of Middle East Economics and Finance, 6(2).

Arellano, M. \& Bond, S., 1991. Some Tests of Specification for Panel Data: Monte Carlo Evidence and an Application to Employment Equations. The Review of economic Studies, 58, 277-297.

Awdeh, A., El-Moussawi, C. \& Machrouh, F., 2011. The Effect of Capital Requirements on Banking Risk. International Research journal of Finance and Economics, 66(66), pp.133-146.

Ayuso, J., Pérez, D. \& Saurina, J., 2004. Are capital buffers pro-cyclical? Evidence from Spanish panel data. Journal of Financial Intermediation, 13(2), pp.249-264.

Bancel, F. \& Mittoo, U.R., 2004. The Determinants of Capital Structure Choice : A Survey of European Firms. Financial Management, 33(4), pp.103-132. Available at: http://www.jstor.org/stable/3666330.

Barth, J.R., Caprio, G. \& Levine, R., 2004. Bank regulation and supervision: What works best? Journal of Financial Intermediation, 13(2), pp.205-248.

Barth, J.R., Caprio, G. \& Levine, R., 2008. Bank Regulations are Changing: For Better or Worse?" Comparative Economic Studies, December, 50(4), pp.537-563. 
Barth, J.R., Caprio, G. \& Levine, R., 2013. "Bank regulation and supervision in 180 countries from 1999 to 2011," Journal of Financial Economic Policy, 5(2), pp.111219

Belkhir, M., Maghyereh, A. \& Awartani, B., 2016. Institutions and corporate capital structure in the MENA region. Emerging Markets Review, 26, pp.99-129. Available at: http://dx.doi.org/10.1016/j.ememar.2016.01.001.

Berger, A., 1995. The relationship between capital and earnings on banking. Journal of Money, Credit \& Banking, v27(n2), p.p432. Available at: http://find.galegroup.com/itx/infomark.do?\&contentSet=IACDocuments\&type $=$ retrieve $\&$ tabID $=$ T002\&prodId $=\mathrm{ITOF} \&$ docId $=\mathrm{A} 16967801 \&$ sourc $\mathrm{e}=$ gale\&srcprod=ITOF\&userGroupName=lom_umichanna\&version $=1.0$.

Berger, A. \& Sedunov, J., 2017 Bank Liquidity Creation and Real Economic Output. Journal of Banking \& Finance, 81, pp.1-19.

Berger, A. et al., 2008. How Do Large Banking Organizations Manage Their Capital Ratios? Journal of Financial Services Research, 34, pp. 123-149

Booth, L., Aivazian, V. \& Demirguc-kunt, A., 2001. Capital Structures in Developing Countries. Journal of Finance, 56(1), pp.87-130.

Bougatef, K. \& Mgadmi, N., 2016. The impact of prudential regulation on bank capital and risk-taking: The case of MENA countries. Spanish Review of Financial Economics. Available at: http://dx.doi.org/10.1016/j.srfe.2015.11.001.

Boyd, J. H., De Nicolò, G. \& Jalal, A. M., 2007. Bank Risk-Taking and Competition

Revisited: New Theory and New Evidence, s.l.: IMF Working Paper WP/06/297.

Brewer, E., Kaufman, G.G. \& Wall, L.D., 2008. Bank capital ratios across countries: Why do they vary? Journal of Financial Services Research, 34(2-3), pp.177-201.

Chen, M. et al., 2015. Corruption and bank risk-taking: Evidence from emerging economies. Emerging Markets Review, 24, pp.122-148.

Cho, S.-S. et al., 2014. Creditor rights and capital structure: Evidence from international data. Journal of Corporate Finance, 25, pp.40-60.

Creane, S. et al., 2004. Financial Sector Development in the Middle East and North Africa. IMF Working Papers. 
De Jong, A., Kabir, R. \& Nguyen, T.T., 2008. Capital structure around the world: The roles of firm- and country-specific determinants. Journal of Banking and Finance, 32(9), pp.1954-1969.

Deesomsak, R., Paudyal, K. \& Pescetto, G., 2004. The determinants of capital structure: Evidence from the Asia Pacific region. Journal of Multinational Financial Management, 14(4-5), pp.387-405.

Demirgüç-Kunt, A., Kane, E. \& Laeven, L., 2014. Deposit Insurance Database. Working Paper of the International monetary Fund, 14(June), pp.1-43.

Demirgüç-Kunt, A. \& Maksimovic, V., 1999. Institutions, financial markets, and firm debt maturity. Journal of Financial Economics, 54(3), pp.295-336. Available at: http://www.sciencedirect.com/science/article/pii/S0304405X99000392.

Diamond, D. \& Rajan, R., 2000. A Theory of Bank Capital. Journal of Finance, 55(6), pp.2431-2465. Available at: http://www.jstor.org.

Distinguin, I., Roulet, C. \& Tarazi, A., 2013. Bank regulatory capital and liquidity: Evidence from US and European publicly traded banks. Journal of Banking and Finance, 37(9), pp.3295-3317.

Distinguin, I., Kouassi, T., Tarazi, A., 2013. Interbank deposits and market discipline: Evidence from Central and Eastern Europe. Journal of Comparative Economics, 41, pp.544-560

Djankov, S., McLiesh, C. \& Shleifer, A., 2007. Private credit in 129 countries. Journal of Financial Economics, 84(2), pp.299-329.

Fan, J., Titman, S. \& Twite, G., 2012. An International Comparison of Capital Structure and Debt Maturity Choices. Journal of Financial and Quantitative Analysis, 47(1), pp.23-56.

Farazi, S., Feyen, E. \& Rocha, R.D.R., 2011. Bank ownership and performance in the Middle East and North Africa Region. World Bank Policy Research Working Paper Series, Vol, (April).

Fiordelisi, F., Marques-Ibanez, D. \& Molyneux, P., 2011. Efficiency and risk in European banking. Journal of Banking and Finance, 35(5), pp.1315-1326. Available at: http://dx.doi.org/10.1016/j.jbankfin.2010.10.005.

Flannery, M.J., 1994. Debt Maturity and the Deadweight Cost of Leverage : Optimally Financing Banking Firms. The American Economic Review, 84(1), pp.320-331.

Flannery, M.J., \& Oztekin, O., 2012. Institutional determinants of capital structure 
adjustment speeds. Journal of Financial Economics, 103, pp.88-112.

Fonseca, A.R. \& González, F., 2010. How bank capital buffers vary across countries: The influence of cost of deposits, market power and bank regulation. Journal of Banking and Finance, 34(4), pp.892-902.

Fu, X., Lin, Y. \& Molyneux, P., 2014. Bank competition and financial stability in Asia Pacific. Journal of Banking \& Finance, Volume 38, p. 64-77.

Gazdar, K. \& Cherif, M., 2015. Institutions and the finance-growth nexus: Empirical evidence from MENA countries. Borsa Istanbul Review, 15(3), pp.137-160. Available at: http://dx.doi.org/10.1016/j.bir.2015.06.001.

Giannetti, M., 2003. Do Better Institutions Mitigate Agency Problems ? Evidence from Corporate Finance Choices. The Journal of Financial and Quantitative Analysis, 38(1), pp.185-212.

González, V. \& González, F., 2008. Influence of bank concentration and institutions on capital structure: New international evidence. Journal of Corporate Finance, 14, pp.363-375.

Gropp, R. \& Heider, F., 2010. The Determinants of Bank Capital Sturcture. Review of Finance, 14, pp.587-622

Gungoraydinoglu, A. \& Öztekin, Ö., 2011. Firm- and country-level determinants of corporate leverage: Some new international evidence. Journal of Corporate Finance, 17(5), pp.1457-1474.

Harding, J.P., Liang, X. \& Ross, S.L., 2013. Bank Capital Requirements, Capital Structure and Regulation. Journal of Financial Services Research, 43(2), pp.127148.

Hausman, J. \& Taylor, W., 1981. Panel Data and Unobservable Individual Effects Author. Econometrica, 49(6), pp.1377-1398.

Haq, M., Hu. D., Faff. R., Pathan. S., 2017. New evidence on national culture and bank capital structure. Pacific-Basin Finance Journal

Huntington, S.P., 1970. Political Order in Changing Societies. Comparative Education Review, 14(3)

Jensen, M.C., 1986. Agency Costs of Free Cash Flow, Corporate Finance, and Takeovers. The American Economic Review, 76, pp.323-329. 
Kaufman, D., Kraay, A., Zoido-Lobaton, P., 2001. Governance matters II: Update indicators for 2001. World Bank.

Keeley, M., 1990. Deposit Insurance, Risk, and Market Power in Banking. The American Economic Review, 80(5), pp.1183-1200.

Kleff, V. \& Weber, M., 2008. How Do Banks Determine Capital ? Evidence from Germany. German Economic Review, 9(3), pp.354-372

Klomp, J. \& Haan, J. De, 2013. Bank regulation, the quality of institutions and banking risk in emerging and developing countries: An empirical analysis. Mimeo, pp.1-57.

Maraghni, H. \& Bouheni, F. Ben, 2015. Bank Capital Ratio, Prudential Regulation and Liquidity Risk Taking: Behavior of Tunisian Banks in a Simultaneous Approach. International Journal of Economics and Finance, 7(6), pp.263-278. Available at: http://www.ccsenet.org/journal/index.php/ijef/article/view/46074.

Mo, P.H., 2001. Corruption and Economic Growth. Journal of Comparative Economics, 29(1), pp.66-79.

Nabi, M. \& Suliman, M., 2008. The Institutional Environment and the Banking - Growth Nexus: Theory and Investigation for MENA. Economic Reserach Forum Working Paper, (392).

Naceur, S. Ben \& Omran, M., 2011. The effects of bank regulations, competition, and financial reforms on banks' performance. Emerging Markets Review, 12(1), pp.120.

Nier, E. \& Baumann, U., 2006. Market discipline, disclosure and moral hazard in banking. Journal of Financial Intermediation, 15(3), pp.332-361.

La Porta, R. et al., 1997. Legal Determinants of External Finance. The Journal of Finance, 52(3).

Laeven, L. \& Levine, R., 2009. Bank governance, regulation and risk taking. Journal of Financial Economics, 93(2), p. 259-275.

Qian, J. \& Strahan, P.E., 2007. How Laws and Institutions Shape Financial Contracts : The Case of Bank Loans. The Journal of Finance, 62(6), pp.2803-2834.

Rime, B., 2001. Capital requirements and bank behavior: Empirical evidence for Switzerland. Journal of Banking \& Finance, 25, pp.789-805. 
Saadaoui, Z., 2015. The Cyclical Behaviour of Bank Capital Buffers: An Empirical Evidence for MENA Banking Systems. Review of Middle East Economics and Finance, 11(2), pp.145-182. Available at: http://www.degruyter.com/view/j/rmeef.2015.11.issue-2/rmeef-2013-0067/rmeef2013-0067.xml.

Sassi, H., 2013. The Impact of Bank Regulations and Institutions on Efficiency in Selected MENA Banks. International Journal of Economics and Finance, 5(8), pp.84-100.

Shim, J., 2013. Bank capital buffer and portfolio risk: The influence of business cycle and revenue diversification. Journal of Banking and Finance, 37(3), pp.761-772. Available at: http://dx.doi.org/10.1016/j.jbankfin.2012.10.002.

Shleifer, A. \& Vishny, R., 1993. Corruption. The Quarterly Journal of Economics, 108(3), pp.599-617.

Shrieves, R. \& Dahl, D., 1992. The relationship between risk and capital in commercial banks. Journal of Banking \& Finance, 16. Available at: http://www.sciencedirect.com/science/article/pii/037842669290024T.

Srairi, S.A., 2010. Cost and profit efficiency of conventional and Islamic banks in GCC countries. Journal of Productivity Analysis, 34(1), pp.45-62.

Turk-Ariss, R., 2009. Competitive behavior in Middle East and North Africa banking systems. Quarterly Review of Economics and Finance, 49(2), pp.693-710.

Wei, S.-J., 2000. How Taxing is Corruption on International Investors? The Review of Economics and Statistics, 82(1), pp.1-11.

World Bank. 2014. Strengthening governance and Institutions in MENA: Issues and priorities. MENA World Knowledge and Learning, Issue 114

World Bank. 2016. What's holding back the private sector in MENA. Lessons from The Enterprise Survey. 


\begin{tabular}{|l|l|l|l|l|l|l|l|}
\cline { 2 - 8 } \multicolumn{1}{l|}{} & All & Conventional & Islamic & Listed & $\begin{array}{l}\text { Non- } \\
\text { listed }\end{array}$ & $\begin{array}{l}\text { Governmentally- } \\
\text { owned }\end{array}$ & $\begin{array}{l}\text { Privately- } \\
\text { owned }\end{array}$ \\
\hline ALGERIA & 1 & 1 & 0 & 0 & 1 & 0 & 1 \\
\hline BAHRAIN & 17 & 8 & 9 & 9 & 8 & 4 & 13 \\
\hline EGYPT & 25 & 22 & 3 & 20 & 5 & 4 & 21 \\
\hline ISRAEL & 7 & 7 & 0 & 6 & 1 & 0 & 7 \\
\hline JORDAN & 14 & 11 & 3 & 12 & 2 & 1 & 13 \\
\hline KUWAIT & 9 & 4 & 5 & 9 & 0 & 2 & 7 \\
\hline LEBANON & 26 & 26 & 0 & 5 & 21 & 3 & 23 \\
\hline MALTA & 4 & 4 & 0 & 2 & 2 & 0 & 4 \\
\hline MOROCCO & 5 & 5 & 0 & 4 & 1 & 0 & 5 \\
\hline OMAN & 6 & 6 & 0 & 5 & 1 & 2 & 4 \\
\hline QATAR & 10 & 6 & 4 & 7 & 3 & 3 & 7 \\
\hline TUNISIA & 1 & 1 & 0 & 0 & 1 & 0 & 1 \\
\hline UNITED ARAB EMIRATES & 20 & 13 & 7 & 16 & 4 & 9 & 11 \\
\hline YEMEN & 4 & 2 & 2 & 0 & 4 & 0 & 4 \\
\hline \hline Grand Total & $\mathbf{1 4 9}$ & $\mathbf{1 1 6}$ & $\mathbf{3 3}$ & $\mathbf{9 5}$ & $\mathbf{5 4}$ & $\mathbf{2 8}$ & $\mathbf{1 2 1}$ \\
\hline
\end{tabular}


Table 2. Descriptive statistics

\begin{tabular}{|c|c|c|c|c|c|c|c|c|}
\hline Variable & & Obs & Mean & $\begin{array}{l}\text { Std. } \\
\text { Dev. }\end{array}$ & Min & Max & Median & Sources \\
\hline \multicolumn{9}{|c|}{ Dependent Variables } \\
\hline TCR & Total capital adequacy ratio & 1307 & 18.665 & 7.334 & 5.95 & 49.660 & 16.7 & $\begin{array}{l}\text { BankScope and } \\
\text { authors' } \\
\text { calculations }\end{array}$ \\
\hline EQTA & Equity to total assets ratio & 1307 & 13.160 & 8.544 & 2.808 & 73 & 11.22 & $\begin{array}{l}\text { BankScope and } \\
\text { authors' } \\
\text { calculations }\end{array}$ \\
\hline \multicolumn{9}{|c|}{ Institutional Variables } \\
\hline PS & Political stability & 1307 & -0.423 & 1060 & -2.527 & 1.393 & -1 & $\begin{array}{c}\text { World Governance } \\
\text { Indicators, World Bank }\end{array}$ \\
\hline GC & Getting credit & 1150 & 40397 & 19860 & 12.500 & 87.5 & 43.75 & $\begin{array}{c}\text { Doing Business } \\
\text { Creditors' Rights } \\
\text { Database }\end{array}$ \\
\hline $\mathrm{RI}$ & Resolving Insolvency & 1212 & 35074 & 10322 & 17.130 & 65.240 & 31.8 & $\begin{array}{c}\text { Doing Business } \\
\text { Creditors' Rights } \\
\text { Database }\end{array}$ \\
\hline $\mathrm{EF}$ & Economic freedom & 1262 & 64197 & 6124 & 49.600 & 77.7 & 64.4 & $\begin{array}{l}\text { World Heritage } \\
\text { Foundation }\end{array}$ \\
\hline $\mathrm{FO}$ & Financial openness & 1262 & 66557 & 8773 & 29.300 & 85.400 & 66.3 & $\begin{array}{c}\text { World Heritage } \\
\text { Foundation and } \\
\text { authors' } \\
\text { calculations } \\
\end{array}$ \\
\hline $\mathrm{CPI}$ & Corruption perception index & 1307 & 46578 & 14760 & 18 & 77 & 48 & $\begin{array}{l}\text { Transparency } \\
\text { International }\end{array}$ \\
\hline \multicolumn{9}{|c|}{ Bank-Level Variables } \\
\hline $\mathrm{ROA}$ & Return on assets ratio & 1272 & 1.381 & 1.373 & -5.761 & 8.501 & 1.230 & $\begin{array}{l}\text { BankScope and } \\
\text { authors' } \\
\text { calculations }\end{array}$ \\
\hline ZSCORE & Probability of Insolvency & 1036 & 1.903 & 1 & 0 & 4.285 & 1.87 & $\begin{array}{c}\text { BankScope and } \\
\text { authors' } \\
\text { calculations }\end{array}$ \\
\hline CONC & Bank concentration & 1307 & 0.173 & 0.074 & 0.082 & 0.429 & 0.139 & $\begin{array}{l}\text { BankScope and } \\
\text { authors' } \\
\text { calculations }\end{array}$ \\
\hline SIZE & Logarithm of total assets & 1307 & 15.24 & 1394 & 10.494 & 18.050 & 15.270 & $\begin{array}{l}\text { BankScope and } \\
\text { authors' } \\
\text { calculations }\end{array}$ \\
\hline Islamic & Dummy variable for Islamic banks & 1307 & 0.17 & 0.383 & 0 & 1 & 0 & Authors' Calculations \\
\hline & Dummy variable for Government-owned banks & & & & & & & \\
\hline Gov & & 1307 & 0.207 & 0.405 & 0 & 1 & 0 & Authors' Calculations \\
\hline Listed & Dummy variable for Large banks & 1307 & 0.647 & 0.477 & 0 & 1 & 1 & Authors' Calculations \\
\hline \multicolumn{9}{|c|}{ Other Country-Level Variables } \\
\hline GDP & GDP growth rate & 1283 & 4741 & 4201 & -15.088 & 26.170 & 4.330 & $\begin{array}{l}\text { World Development } \\
\text { Indicators }\end{array}$ \\
\hline REG & Regulatory stringency & 1307 & 1407 & 1400 & 0 & 3 & 1 & $\begin{array}{c}\text { World Bank } \\
\text { Regulation and } \\
\text { Supervisory Database; } \\
\text { (Barth et al. 2004, } \\
2008,2013) .\end{array}$ \\
\hline DEP_INS & Deposit insurance & 1307 & 0.545 & 0.498 & 0 & 1 & 1 & $\begin{array}{c}\text { World Bank Database; } \\
\text { Barth } \\
\text { et al. (2003) }\end{array}$ \\
\hline
\end{tabular}

This table reports the descriptive statistics of our sample which extends from 2004 to 2014 . All the ratios are expressed in percentages. Size is the natural logarithm of total assets which is in thousand U.S Dollars. 
Table 3: Average values of Capital ratios by country over the sample period 2004-2014

\begin{tabular}{|c|c|c|c|c|c|c|c|c|c|c|c|c|}
\hline & & 2004 & 2005 & 2006 & 2007 & 2008 & 2009 & 2010 & 2011 & 2012 & 2013 & 2014 \\
\hline Algeria & $\begin{array}{l}\text { TCR } \\
\text { EQTA }\end{array}$ & $\begin{array}{l}21.1 \\
10.1\end{array}$ & $\begin{array}{l}21.8 \\
11.0\end{array}$ & $\begin{array}{l}17.1 \\
8.8\end{array}$ & $\begin{array}{l}19.7 \\
9.9\end{array}$ & $\begin{array}{l}18.6 \\
8.7\end{array}$ & $\begin{array}{l}20.0 \\
10.6\end{array}$ & $\begin{array}{l}18.4 \\
10.8\end{array}$ & $\begin{array}{l}20.0 \\
11.9\end{array}$ & 0.0 & $\begin{array}{l}49.0 \\
33.5\end{array}$ & $\begin{array}{l}36.0 \\
32.2\end{array}$ \\
\hline Bahrain & $\begin{array}{l}\text { TCR } \\
\text { EQTA }\end{array}$ & $\begin{array}{l}23.0 \\
13.7\end{array}$ & $\begin{array}{l}23.2 \\
18.7\end{array}$ & $\begin{array}{l}21.1 \\
15.9\end{array}$ & $\begin{array}{l}25.2 \\
22.8\end{array}$ & $\begin{array}{l}21.5 \\
21.9\end{array}$ & $\begin{array}{l}20.9 \\
19.8\end{array}$ & $\begin{array}{l}21.1 \\
15.9\end{array}$ & $\begin{array}{l}21.9 \\
18.5\end{array}$ & $\begin{array}{l}20.6 \\
21.0\end{array}$ & $\begin{array}{l}21.6 \\
25.8\end{array}$ & $\begin{array}{l}22.6 \\
25.6\end{array}$ \\
\hline Egypt & $\begin{array}{l}\text { TCR } \\
\text { EQTA }\end{array}$ & $\begin{array}{l}12.7 \\
7.4 \\
\end{array}$ & $\begin{array}{l}15.7 \\
7.9\end{array}$ & $\begin{array}{l}14.0 \\
8.7 \\
\end{array}$ & $\begin{array}{l}12.8 \\
7.9 \\
\end{array}$ & $\begin{array}{l}12.6 \\
7.9 \\
\end{array}$ & $\begin{array}{l}20.5 \\
10.8 \\
\end{array}$ & $\begin{array}{l}19.0 \\
10.1 \\
\end{array}$ & $\begin{array}{l}18.2 \\
9.5\end{array}$ & $\begin{array}{l}16.3 \\
10.0 \\
\end{array}$ & $\begin{array}{l}16.4 \\
10.1 \\
\end{array}$ & $\begin{array}{l}16.7 \\
10.3 \\
\end{array}$ \\
\hline Israel & $\begin{array}{l}\text { TCR } \\
\text { EQTA }\end{array}$ & $\begin{array}{l}11.8 \\
5.8\end{array}$ & $\begin{array}{l}11.9 \\
5.5\end{array}$ & $\begin{array}{l}12.1 \\
6.0\end{array}$ & $\begin{array}{l}11.7 \\
5.9\end{array}$ & $\begin{array}{l}12.8 \\
5.7\end{array}$ & $\begin{array}{l}14.5 \\
6.3\end{array}$ & $\begin{array}{l}14.4 \\
6.1\end{array}$ & $\begin{array}{l}14.4 \\
5.8\end{array}$ & $\begin{array}{l}15.2 \\
6.1\end{array}$ & $\begin{array}{l}15.2 \\
5.9\end{array}$ & $\begin{array}{l}15.1 \\
5.9\end{array}$ \\
\hline Jordan & $\begin{array}{l}\text { TCR } \\
\text { EQTA }\end{array}$ & $\begin{array}{l}17.5 \\
11.1\end{array}$ & $\begin{array}{l}18.1 \\
12.5\end{array}$ & $\begin{array}{l}20.4 \\
14.3\end{array}$ & $\begin{array}{l}18.9 \\
13.4\end{array}$ & $\begin{array}{l}20.3 \\
15.7\end{array}$ & \begin{tabular}{|l|}
19.1 \\
13.8
\end{tabular} & $\begin{array}{l}19.8 \\
13.2\end{array}$ & $\begin{array}{l}17.9 \\
13.3\end{array}$ & $\begin{array}{l}20.4 \\
14.8\end{array}$ & $\begin{array}{l}20.0 \\
14.5\end{array}$ & $\begin{array}{l}20.1 \\
14.0\end{array}$ \\
\hline Kuwait & $\begin{array}{l}\text { TCR } \\
\text { EQTA }\end{array}$ & $\begin{array}{l}16.5 \\
12.6\end{array}$ & \begin{tabular}{|l}
19.3 \\
13.6
\end{tabular} & $\begin{array}{l}18.7 \\
13.2\end{array}$ & $\begin{array}{l}18.9 \\
13.7\end{array}$ & $\begin{array}{l}17.1 \\
12.6\end{array}$ & $\begin{array}{l}16.1 \\
11.3\end{array}$ & $\begin{array}{l}20.4 \\
13.7\end{array}$ & $\begin{array}{l}19.9 \\
12.8\end{array}$ & $\begin{array}{l}19.9 \\
12.5\end{array}$ & $\begin{array}{l}22.6 \\
13.7\end{array}$ & $\begin{array}{l}19.6 \\
12.8\end{array}$ \\
\hline Lebanon & $\begin{array}{l}\text { TCR } \\
\text { EQTA }\end{array}$ & $\begin{array}{l}23.1 \\
6.6\end{array}$ & $\begin{array}{l}24.6 \\
7.7\end{array}$ & $\begin{array}{l}24.9 \\
8.0\end{array}$ & $\begin{array}{l}22.9 \\
7.7\end{array}$ & $\begin{array}{l}22.1 \\
8.5\end{array}$ & $\begin{array}{l}16.6 \\
8.9\end{array}$ & $\begin{array}{l}15.1 \\
11.8\end{array}$ & $\begin{array}{l}12.3 \\
9.8\end{array}$ & $\begin{array}{l}13.5 \\
10.2\end{array}$ & $\begin{array}{l}14.7 \\
10.4\end{array}$ & $\begin{array}{l}15.1 \\
10.6\end{array}$ \\
\hline Malta & $\begin{array}{l}\text { TCR } \\
\text { EQTA }\end{array}$ & $\begin{array}{l}16.1 \\
7.2 \\
\end{array}$ & $\begin{array}{l}16.7 \\
7.7 \\
\end{array}$ & $\begin{array}{l}14.2 \\
7.1 \\
\end{array}$ & $\begin{array}{l}14.2 \\
6.7 \\
\end{array}$ & $\begin{array}{l}22.6 \\
17.4 \\
\end{array}$ & $\begin{array}{l}16.8 \\
17.8 \\
\end{array}$ & $\begin{array}{l}15.9 \\
17.0 \\
\end{array}$ & $\begin{array}{l}15.4 \\
16.7 \\
\end{array}$ & $\begin{array}{l}13.2 \\
7.0\end{array}$ & $\begin{array}{l}13.8 \\
7.4 \\
\end{array}$ & $\begin{array}{l}14.1 \\
8.3 \\
\end{array}$ \\
\hline Morocco & $\begin{array}{l}\text { TCR } \\
\text { EQTA }\end{array}$ & $\begin{array}{l}8.5 \\
8.7 \\
\end{array}$ & $\begin{array}{l}12.6 \\
8.8\end{array}$ & $\begin{array}{l}10.8 \\
8.4 \\
\end{array}$ & $\begin{array}{l}8.9 \\
7.8 \\
\end{array}$ & $\begin{array}{l}11.2 \\
7.6 \\
\end{array}$ & $\begin{array}{l}11.2 \\
8.7 \\
\end{array}$ & $\begin{array}{l}12.2 \\
9.8 \\
\end{array}$ & $\begin{array}{l}11.9 \\
9.4 \\
\end{array}$ & $\begin{array}{l}13.1 \\
10.0 \\
\end{array}$ & $\begin{array}{l}13.6 \\
9.9 \\
\end{array}$ & $\begin{array}{l}13.6 \\
10.6 \\
\end{array}$ \\
\hline Oman & $\begin{array}{l}\text { TCR } \\
\text { EQTA }\end{array}$ & $\begin{array}{l}18.1 \\
12.9 \\
\end{array}$ & $\begin{array}{l}19.7 \\
15.2 \\
\end{array}$ & $\begin{array}{l}16.5 \\
13.7\end{array}$ & $\begin{array}{l}15.0 \\
13.7 \\
\end{array}$ & $\begin{array}{l}14.0 \\
13.6 \\
\end{array}$ & $\begin{array}{l}14.7 \\
13.5 \\
\end{array}$ & $\begin{array}{l}15.0 \\
13.6 \\
\end{array}$ & $\begin{array}{l}14.7 \\
12.0 \\
\end{array}$ & $\begin{array}{l}15.4 \\
11.9 \\
\end{array}$ & $\begin{array}{l}15.9 \\
12.4 \\
\end{array}$ & $\begin{array}{l}19.6 \\
17.6 \\
\end{array}$ \\
\hline Qatar & $\begin{array}{l}\text { TCR } \\
\text { EQTA }\end{array}$ & $\begin{array}{l}28.2 \\
18.1\end{array}$ & $\begin{array}{l}21.8 \\
19.7 \\
\end{array}$ & $\begin{array}{l}18.0 \\
17.2\end{array}$ & $\begin{array}{l}20.0 \\
19.5 \\
\end{array}$ & $\begin{array}{l}18.4 \\
19.0 \\
\end{array}$ & \begin{tabular}{|l}
18.1 \\
18.1 \\
\end{tabular} & $\begin{array}{l}20.9 \\
19.1 \\
\end{array}$ & $\begin{array}{l}21.1 \\
18.2\end{array}$ & $\begin{array}{l}17.3 \\
16.5 \\
\end{array}$ & $\begin{array}{l}17.2 \\
15.4 \\
\end{array}$ & $\begin{array}{l}17.1 \\
17.6 \\
\end{array}$ \\
\hline Tunisia & $\begin{array}{l}\text { TCR } \\
\text { EQTA }\end{array}$ & $\begin{array}{l}24.0 \\
7.4 \\
\end{array}$ & $\begin{array}{l}27.2 \\
9.2 \\
\end{array}$ & $\begin{array}{l}24.9 \\
7.9 \\
\end{array}$ & $\begin{array}{l}28.6 \\
7.2 \\
\end{array}$ & $\begin{array}{l}28.7 \\
7.1 \\
\end{array}$ & & & $\begin{array}{l}26.5 \\
9.2 \\
\end{array}$ & $\begin{array}{l}22.2 \\
3.7\end{array}$ & $\begin{array}{l}31.5 \\
8.3\end{array}$ & \\
\hline UAE & $\begin{array}{l}\text { TCR } \\
\text { EQTA }\end{array}$ & $\begin{array}{l}22.5 \\
23.0 \\
\end{array}$ & $\begin{array}{l}27.1 \\
21.8 \\
\end{array}$ & $\begin{array}{l}19.7 \\
16.7 \\
\end{array}$ & $\begin{array}{l}18.1 \\
14.9 \\
\end{array}$ & $\begin{array}{l}16.7 \\
14.6 \\
\end{array}$ & $\begin{array}{l}21.4 \\
15.7\end{array}$ & $\begin{array}{l}21.8 \\
15.6\end{array}$ & $\begin{array}{l}22.4 \\
16.6\end{array}$ & $\begin{array}{l}22.3 \\
17.1 \\
\end{array}$ & $\begin{array}{l}20.8 \\
16.5\end{array}$ & $\begin{array}{l}18.9 \\
15.6\end{array}$ \\
\hline Yemen & $\begin{array}{l}\text { TCR } \\
\text { EQTA }\end{array}$ & $\begin{array}{l}46.0 \\
8.0\end{array}$ & $\begin{array}{l}11.6 \\
8.0\end{array}$ & $\begin{array}{l}29.3 \\
10.2\end{array}$ & $\begin{array}{l}26.5 \\
13.8\end{array}$ & $\begin{array}{l}16.3 \\
15.6\end{array}$ & \begin{tabular}{|l|}
17.3 \\
11.8
\end{tabular} & $\begin{array}{l}17.7 \\
11.2\end{array}$ & $\begin{array}{l}22.1 \\
12.9\end{array}$ & $\begin{array}{l}28.6 \\
11.0\end{array}$ & $\begin{array}{l}25.2 \\
9.6\end{array}$ & $\begin{array}{l}29.5 \\
9.2\end{array}$ \\
\hline $\begin{array}{l}\text { MENA } \\
\text { Average }\end{array}$ & $\begin{array}{l}\text { TCR } \\
\text { EQTA }\end{array}$ & $\begin{array}{l}20.0 \\
11.6\end{array}$ & $\begin{array}{l}20.5 \\
12.7\end{array}$ & $\begin{array}{l}19.3 \\
12.0\end{array}$ & $\begin{array}{l}19.6 \\
13.3\end{array}$ & $\begin{array}{l}18.6 \\
14.0\end{array}$ & $\begin{array}{l}18.3 \\
13.2\end{array}$ & $\begin{array}{l}18.4 \\
13.2\end{array}$ & $\begin{array}{l}17.9 \\
12.8\end{array}$ & $\begin{array}{l}17.9 \\
13.0\end{array}$ & $\begin{array}{l}18.4 \\
13.7\end{array}$ & $\begin{array}{l}18.3 \\
14.3\end{array}$ \\
\hline $\begin{array}{l}\text { MENA } \\
\text { Count }\end{array}$ & $\begin{array}{l}\text { TCR } \\
\text { EQTA }\end{array}$ & $\begin{array}{l}77 \\
77\end{array}$ & $\begin{array}{l}81 \\
81\end{array}$ & $\begin{array}{l}95 \\
95\end{array}$ & $\begin{array}{l}101 \\
101\end{array}$ & $\begin{array}{l}107 \\
107\end{array}$ & $\begin{array}{l}129 \\
129\end{array}$ & $\begin{array}{l}135 \\
135\end{array}$ & $\begin{array}{l}141 \\
141\end{array}$ & $\begin{array}{l}149 \\
149\end{array}$ & $\begin{array}{l}149 \\
149\end{array}$ & $\begin{array}{l}143 \\
143\end{array}$ \\
\hline
\end{tabular}

TCR is the total capital adequacy ratio calculated as the sum of Tier 1 and Tier 2 capital to total risk weighted assets.

EQTA is the equity to total unweighted assets ratio. 
Table 4: Average values of institutional variables by country over the sample period 2004-2014

\begin{tabular}{|c|c|c|c|c|c|c|}
\hline & PS & GC & $\mathbf{R I}$ & EF & FO & CPI \\
\hline Algeria & -1.37 & 21.25 & 54.72 & 55.34 & 48.73 & 30.50 \\
\hline Bahrain & -0.36 & 38.39 & 42.91 & 74.94 & 77.94 & 53.08 \\
\hline Egypt & -0.80 & 37.50 & 20.92 & 54.89 & 49.36 & 31.50 \\
\hline Israel & -1.27 & 86.25 & 55.92 & 65.51 & 69.73 & 61.50 \\
\hline Jordan & -0.35 & 13.75 & 29.21 & 66.18 & 66.22 & 49.25 \\
\hline Kuwait & 0.28 & 47.50 & 32.80 & 65.89 & 64.29 & 44.92 \\
\hline Lebanon & -1.29 & 37.50 & 32.28 & 59.20 & 66.38 & 28.67 \\
\hline Malta & 1.27 & 18.75 & 42.16 & & & 58.73 \\
\hline Morocco & -0.37 & 34.38 & 34.42 & 59.38 & 52.40 & 34.42 \\
\hline Oman & 0.78 & 40.00 & 37.88 & 66.42 & 63.16 & 53.17 \\
\hline Qatar & 1.00 & 27.68 & 57.72 & 65.52 & 61.28 & 64.67 \\
\hline Tunisia & -0.08 & 37.50 & 55.89 & 59.82 & 44.27 & 43.67 \\
\hline United Arab Emirates & 0.86 & 43.75 & 29.98 & 69.19 & 62.19 & 63.00 \\
\hline Yemen & -1.82 & 13.75 & 25.07 & 51.10 & 48.03 & 22.92 \\
\hline
\end{tabular}

PS is the measure of political stability. GC is the first component of creditors' rights and measures the ease of getting credit. RI is the other component of the creditors' rights index and it accounts for the ease of resolving insolvency, as well as liquidation. EF is the economic freedom index. FO is a measure of financial openness and includes financial and trade freedom. CPI is a corruption perception index accounting for the level of perceived corruption in each country. 
Table 5: Correlation matrix

\begin{tabular}{|c|c|c|c|c|c|c|c|c|c|c|c|c|c|}
\hline & ROA & ZSCORE & CONC & GDP & SIZE & REG & DEP_INS & PS & $\mathrm{GC}$ & RI & $\mathrm{EF}$ & FO & $\mathrm{CPI}$ \\
\hline ROA & 1 & & & & & & & & & & & & \\
\hline ZSCORE & 0.1059 & 1 & & & & & & & & & & & \\
\hline CONC & 0.0805 & -0.0913 & 1 & & & & & & & & & & \\
\hline GDP & 0.233 & 0.0533 & 0.1309 & 1 & & & & & & & & & \\
\hline SIZE & -0.0197 & 0.1566 & -0.015 & 0.0172 & 1 & & & & & & & & \\
\hline REG & -0.025 & 0.1069 & -0.0549 & -0.2232 & 0.199 & 1 & & & & & & & \\
\hline DEP_INS & -0.087 & 0.1058 & 0.2036 & -0.1176 & -0.3024 & -0.1863 & 1 & & & & & & \\
\hline PS & 0.2324 & 0.0181 & 0.1695 & 0.2027 & 0.1975 & 0.0896 & -0.399 & 1 & & & & & \\
\hline GC & -0.1264 & 0.0533 & -0.2512 & -0.1967 & 0.2857 & 0.322 & -0.3715 & 0.0153 & 1 & & & & \\
\hline RI & 0.0267 & 0.0261 & 0.1451 & 0.0463 & 0.0247 & 0.1401 & 0.0344 & 0.0672 & 0.1536 & 1 & & & \\
\hline $\mathrm{EF}$ & 0.0618 & 0.0738 & -0.0044 & 0.1039 & 0.0949 & 0.2051 & 0.0059 & 0.4547 & 0.2788 & 0.1267 & 1 & & \\
\hline FO & -0.0439 & 0.1161 & -0.113 & 0.0612 & 0.0522 & 0.1502 & 0.3196 & -0.0268 & 0.3479 & -0.0651 & 1 & 1 & \\
\hline CPI & 0.1995 & 0.0151 & 0.1505 & 0.183 & 0.2505 & 0.2528 & -0.3655 & 0.7766 & 0.2528 & 0.2653 & 0.7132 & 0.305 & 1 \\
\hline
\end{tabular}


Table 6: Mean tests - TCR: High versus low institutional development

\begin{tabular}{|c|c|c|}
\hline \multicolumn{3}{|c|}{ TCR } \\
\hline \multirow{3}{*}{ PS } & Low $(\mathrm{N}=990)$ & 19 \\
\hline & $\operatorname{High}(\mathrm{N}=946)$ & 19.29 \\
\hline & t-stat & $-2.15 * *$ \\
\hline \multirow{3}{*}{ GC } & Low $(\mathrm{N}=649)$ & 20.41 \\
\hline & High $(N=758)$ & 17.16 \\
\hline & t-stat & $8.36 * * *$ \\
\hline \multirow{3}{*}{ RI } & Low $(\mathrm{N}=765)$ & 19.46 \\
\hline & High $(N=596)$ & 17.63 \\
\hline & t-stat & $4.51^{* * *}$ \\
\hline \multirow{3}{*}{ EF } & $\operatorname{Low}(\mathrm{N}=724)$ & 18.38 \\
\hline & High $(\mathrm{N}=1361)$ & 19.06 \\
\hline & t-stat & $-1.91^{* * *}$ \\
\hline \multirow{3}{*}{ FO } & Low $(\mathrm{N}=573)$ & 19.1 \\
\hline & High $(\mathrm{N}=1500)$ & 18.77 \\
\hline & t-stat & 0.85 \\
\hline \multirow{3}{*}{$\mathrm{CPI}$} & Low $(\mathrm{N}=629)$ & 18.19 \\
\hline & High $(\mathrm{N}=1040)$ & 19.32 \\
\hline & t-stat & $-2.93 * * *$ \\
\hline
\end{tabular}

This table represents a two group T-test on TCR between countries with high institutional development compared to countries with low institutional development. 
Table 7: The impact of institutional variables on bank capital - Main Regression

\begin{tabular}{|c|c|c|c|c|c|c|c|c|c|c|c|c|c|c|}
\hline & (1) & (2) & (3) & (4) & (5) & (6) & (7) & (8) & (9) & (10) & (11) & (12) & (13) & (14) \\
\hline & \multicolumn{7}{|c|}{ Panel A: TCR } & \multicolumn{7}{|c|}{ Panel B: EQTA } \\
\hline PS & $\begin{array}{l}0.883 * \\
(1.91)\end{array}$ & & & & & & & $\begin{array}{l}-0.348 \\
-1.35)\end{array}$ & & & & & & \\
\hline $\mathrm{GC}$ & & $\begin{array}{l}-0.0867^{* * *} \\
(-5.02)\end{array}$ & & & & & & & $\begin{array}{l}0.0091 \\
(1.24)\end{array}$ & & & & & \\
\hline $\mathrm{RI}$ & & & $\begin{array}{l}0.232^{* * *} \\
(-3.47)\end{array}$ & & & & & & & $\begin{array}{l}-0.0483^{*} \\
(-1.72)\end{array}$ & & & & \\
\hline EF & & & & $\begin{array}{l}0.465^{* * *} \\
(6.24)\end{array}$ & & & & & & & $\begin{array}{l}0.0307 \\
(0.90)\end{array}$ & & & \\
\hline FO & & & & & $\begin{array}{l}0.430^{* * *} \\
(10.07)\end{array}$ & & & & & & & $\begin{array}{l}0.00291 \\
(0.14)\end{array}$ & & \\
\hline CPI & & & & & & $\begin{array}{l}0.143^{* * *} \\
(3.82)\end{array}$ & & & & & & & $\begin{array}{l}0.0328^{*} \\
(1.93)\end{array}$ & \\
\hline IFI & & & & & & & $\begin{array}{l}6.196^{* * *} \\
(8.50)\end{array}$ & & & & & & & $\begin{array}{l}0.440 \\
(1.35)\end{array}$ \\
\hline CRT & & & & & & & $\begin{array}{l}-2.407^{* * *} \\
(-5.63)\end{array}$ & & & & & & & $\begin{array}{l}0.265 \\
(1.47)\end{array}$ \\
\hline CONC & $\begin{array}{l}0.829 \\
(0.13)\end{array}$ & $\begin{array}{l}0.315 \\
(0.04)\end{array}$ & $\begin{array}{l}7.794 \\
(0.93)\end{array}$ & $\begin{array}{l}9.131 \\
(1.41)\end{array}$ & $\begin{array}{l}-8.486 \\
(-1.37)\end{array}$ & $\begin{array}{l}2.866 \\
(0.46)\end{array}$ & $\begin{array}{l}9.032 \\
(1.10)\end{array}$ & $\begin{array}{l}-3.136 \\
(-1.09)\end{array}$ & $\begin{array}{l}-3.296 \\
(-0.93)\end{array}$ & $\begin{array}{l}-3.650 \\
(-1.04)\end{array}$ & $\begin{array}{l}-2.096 \\
(-0.70)\end{array}$ & $\begin{array}{l}-2.726 \\
(-0.93)\end{array}$ & $\begin{array}{l}-2.750 \\
(-0.96)\end{array}$ & $\begin{array}{l}-3.723 \\
(-1.04)\end{array}$ \\
\hline GDP & $\begin{array}{l}0.0141 \\
(0.31)\end{array}$ & $\begin{array}{l}0.0306 \\
(0.62)\end{array}$ & $\begin{array}{l}0.0269 \\
(0.54)\end{array}$ & $\begin{array}{l}0.0114 \\
(0.25)\end{array}$ & $\begin{array}{l}0.0226 \\
(0.51)\end{array}$ & $\begin{array}{l}0.00779 \\
(0.17)\end{array}$ & $\begin{array}{l}0.0105 \\
(0.22)\end{array}$ & $\begin{array}{l}-0.00788 \\
(-0.38)\end{array}$ & $\begin{array}{l}0.000221 \\
(0.01)\end{array}$ & $\begin{array}{l}-0.00255 \\
(-0.12)\end{array}$ & $\begin{array}{l}-0.00405 \\
(-0.19)\end{array}$ & $\begin{array}{l}-0.00389 \\
(-0.19)\end{array}$ & $\begin{array}{l}-0.00842 \\
(-0.41)\end{array}$ & $\begin{array}{l}-0.00138 \\
(-0.07)\end{array}$ \\
\hline REG & $\begin{array}{l}0.00824 \\
(0.04) \\
-\end{array}$ & $\begin{array}{l}-0.138 \\
(-0.66)\end{array}$ & $\begin{array}{l}-0.347 \\
(-1.50) \\
-\end{array}$ & $\begin{array}{l}0.175 \\
(0.86) \\
-\end{array}$ & $\begin{array}{l}0.176 \\
(0.90) \\
-\end{array}$ & $\begin{array}{l}-0.0203 \\
(-0.10) \\
-\end{array}$ & $\begin{array}{l}-0.127 \\
(-0.61)\end{array}$ & $\begin{array}{l}0.119 \\
(1.32) \\
-\end{array}$ & $\begin{array}{l}0.259^{* * *} \\
(3.01) \\
-\end{array}$ & $\begin{array}{l}0.143 \\
(1.46) \\
-\end{array}$ & $\begin{array}{l}0.137 \\
(1.48) \\
-\end{array}$ & $\begin{array}{l}0.126 \\
(1.37) \\
-\end{array}$ & $\begin{array}{l}0.114 \\
(1.27) \\
-\end{array}$ & $\begin{array}{l}0.306^{* * *} \\
(3.42) \\
-\end{array}$ \\
\hline SIZE & $\begin{array}{l}4.869 * * * \\
(-8.22)\end{array}$ & $\begin{array}{l}-4.517^{* * *} \\
(-6.71)\end{array}$ & $\begin{array}{l}3.667^{* * *} \\
(-5.94)\end{array}$ & $\begin{array}{l}4.584^{* * *} \\
(-7.89)\end{array}$ & $\begin{array}{l}4.529^{* * *} \\
(-8.05)\end{array}$ & $\begin{array}{l}5.249^{* * *} \\
(-8.91)\end{array}$ & $\begin{array}{l}-4.385^{* * *} \\
(-6.76)\end{array}$ & $\begin{array}{l}3.927^{* * *} \\
(-13.32)\end{array}$ & $\begin{array}{l}5.066^{* * *} \\
(-15.13)\end{array}$ & $\begin{array}{l}4.365 * * * \\
(-14.05)\end{array}$ & $\begin{array}{l}4.118^{* * *} \\
(-13.98)\end{array}$ & $\begin{array}{l}4.134^{* * *} \\
(-14.03)\end{array}$ & $\begin{array}{l}4.120^{* * *} \\
(-14.12)\end{array}$ & $\begin{array}{l}4.992^{* * *} \\
(-14.93)\end{array}$ \\
\hline
\end{tabular}




\begin{tabular}{|c|c|c|c|c|c|c|c|c|c|c|c|c|c|c|}
\hline ROA & $\begin{array}{l}-0.558^{* *} \\
(-2.52)\end{array}$ & $\begin{array}{l}-0.602^{* *} \\
(-2.40)\end{array}$ & $\begin{array}{l}-0.535^{* *} \\
(-2.12)\end{array}$ & $\begin{array}{l}-0.436 * * \\
(-1.96)\end{array}$ & $\begin{array}{l}-0.328 \\
(-1.53)\end{array}$ & $\begin{array}{l}-0.469 * * \\
(-2.13)\end{array}$ & $\begin{array}{l}-0.245 \\
(-1.01)\end{array}$ & $\begin{array}{l}1.058 * * * \\
(10.62)\end{array}$ & $\begin{array}{l}1.304^{* * *} \\
(12.61)\end{array}$ & $\begin{array}{l}1.393 * * * \\
(13.22)\end{array}$ & $\begin{array}{l}1.066 * * * \\
(10.53)\end{array}$ & $\begin{array}{l}1.058^{* * *} \\
(10.44)\end{array}$ & $\begin{array}{l}1.080 * * * \\
(10.80)\end{array}$ & $\begin{array}{l}1.337 * * * \\
(12.73)\end{array}$ \\
\hline ZSCORE & $\begin{array}{l}0.0923 \\
(0.51)\end{array}$ & $\begin{array}{l}0.171 \\
(0.92)\end{array}$ & $\begin{array}{l}0.0886 \\
(0.48)\end{array}$ & $\begin{array}{l}0.0573 \\
(0.32)\end{array}$ & $\begin{array}{l}0.0916 \\
(0.53)\end{array}$ & $\begin{array}{l}0.0706 \\
(0.40)\end{array}$ & $\begin{array}{l}0.0802 \\
(0.45)\end{array}$ & $\begin{array}{l}0.0233 \\
(0.29)\end{array}$ & $\begin{array}{l}0.0551 \\
(0.72)\end{array}$ & $\begin{array}{l}-0.0156 \\
(-0.20)\end{array}$ & $\begin{array}{l}0.0136 \\
(0.17)\end{array}$ & $\begin{array}{l}0.0162 \\
(0.20)\end{array}$ & $\begin{array}{l}0.0106 \\
(0.13)\end{array}$ & $\begin{array}{l}0.0451 \\
(0.59)\end{array}$ \\
\hline DEP_INS & $\begin{array}{l}7.946 \\
(1.30)\end{array}$ & $\begin{array}{l}5.169 \\
(0.86)\end{array}$ & $\begin{array}{l}15.11^{* * *} \\
(2.60)\end{array}$ & $\begin{array}{l}8.101 \\
(1.35)\end{array}$ & $\begin{array}{l}11.96 * * \\
(2.04)\end{array}$ & $\begin{array}{l}7.477 \\
(1.18)\end{array}$ & $\begin{array}{l}9.876^{*} \\
(1.67)\end{array}$ & $\begin{array}{l}4.694 \\
(1.07)\end{array}$ & $\begin{array}{l}3.309 \\
(0.62)\end{array}$ & $\begin{array}{l}5.156 \\
(1.06)\end{array}$ & $\begin{array}{l}4.380 \\
(0.96)\end{array}$ & $\begin{array}{l}4.396 \\
(0.96)\end{array}$ & $\begin{array}{l}4.494 \\
(1.00)\end{array}$ & $\begin{array}{l}2.698 \\
(0.51)\end{array}$ \\
\hline Islamic & $\begin{array}{l}-0.975 \\
(-0.51)\end{array}$ & $\begin{array}{l}-1.391 \\
(-0.74)\end{array}$ & $\begin{array}{l}-1.321 \\
(-0.77)\end{array}$ & $\begin{array}{l}-0.975 \\
(-0.52)\end{array}$ & $\begin{array}{l}-0.862 \\
(-0.47)\end{array}$ & $\begin{array}{l}-1.099 \\
(-0.55)\end{array}$ & $\begin{array}{l}-1.321 \\
(-0.72)\end{array}$ & $\begin{array}{l}-0.177 \\
(-0.13)\end{array}$ & $\begin{array}{l}-0.553 \\
(-0.33)\end{array}$ & $\begin{array}{l}-0.465 \\
(-0.31)\end{array}$ & $\begin{array}{l}-0.243 \\
(-0.17)\end{array}$ & $\begin{array}{l}-0.243 \\
(-0.17)\end{array}$ & $\begin{array}{l}-0.226 \\
(-0.16)\end{array}$ & $\begin{array}{l}-0.547 \\
(-0.33)\end{array}$ \\
\hline Gov & $\begin{array}{l}4.341 * * \\
(2.40)\end{array}$ & $\begin{array}{l}3.748^{* *} \\
(2.11)\end{array}$ & $\begin{array}{l}3.419 * * \\
(2.09)\end{array}$ & $\begin{array}{l}4.045^{* *} \\
(2.27)\end{array}$ & $\begin{array}{l}4.277^{* *} \\
(2.47)\end{array}$ & $\begin{array}{l}4.665^{* *} \\
(2.48)\end{array}$ & $\begin{array}{l}3.652 * * \\
(2.09)\end{array}$ & $\begin{array}{l}3.935^{* * *} \\
(3.07)\end{array}$ & $\begin{array}{l}4.433^{* * *} \\
(2.86)\end{array}$ & $\begin{array}{l}4.029 * * * \\
(2.87)\end{array}$ & $\begin{array}{l}4.063^{* * *} \\
(3.05)\end{array}$ & $\begin{array}{l}4.082^{* * *} \\
(3.06)\end{array}$ & $\begin{array}{l}4.089 * * * \\
(3.10)\end{array}$ & $\begin{array}{l}4.371 * * * \\
(2.84)\end{array}$ \\
\hline Listed & $\begin{array}{l}4.772 * * * \\
(2.63)\end{array}$ & $\begin{array}{l}3.846^{* *} \\
(2.15)\end{array}$ & $\begin{array}{l}3.458^{* *} \\
(2.10)\end{array}$ & $\begin{array}{l}4.592^{* *} \\
(2.55)\end{array}$ & $\begin{array}{l}4.364^{* *} \\
(2.49)\end{array}$ & $\begin{array}{l}5.108^{* * *} \\
(2.72)\end{array}$ & $\begin{array}{l}3.860 * * \\
(2.17)\end{array}$ & $\begin{array}{l}2.595^{* *} \\
(2.03)\end{array}$ & $\begin{array}{l}2.939 * \\
(1.89)\end{array}$ & $\begin{array}{l}2.447^{*} \\
(1.73)\end{array}$ & $\begin{array}{l}2.610 * \\
(1.93)\end{array}$ & $\begin{array}{l}2.618^{*} \\
(1.93)\end{array}$ & $\begin{array}{l}2.776^{* *} \\
(2.11)\end{array}$ & $\begin{array}{l}2.818^{*} \\
(1.80)\end{array}$ \\
\hline Constant & $\begin{array}{l}88.30^{* * *} \\
(9.44)\end{array}$ & $\begin{array}{l}89.09 * * * \\
(8.65) \\
\end{array}$ & $\begin{array}{l}76.53^{* * *} \\
(7.95)\end{array}$ & $\begin{array}{l}56.25^{* * *} \\
(5.45) \\
\end{array}$ & $\begin{array}{l}59.84 * * * \\
(6.53) \\
\end{array}$ & $\begin{array}{l}88.75^{* * *} \\
(9.76)\end{array}$ & $\begin{array}{l}86.39 * * * \\
(8.63) \\
\end{array}$ & $\begin{array}{l}66.41^{* * *} \\
(13.85) \\
\end{array}$ & $\begin{array}{l}82.54^{* * *} \\
(15.39)\end{array}$ & $\begin{array}{l}74.74 * * * \\
(14.85) \\
\end{array}$ & $\begin{array}{l}67.90 * * * \\
(12.88) \\
\end{array}$ & $\begin{array}{l}69.82^{* * *} \\
(14.18) \\
\end{array}$ & $\begin{array}{l}68.56^{* * *} \\
(14.77) \\
\end{array}$ & $\begin{array}{l}83.04^{* * *} \\
(15.39)\end{array}$ \\
\hline Observations & 1015 & 894 & 943 & 985 & 985 & 1015 & 888 & 1015 & 894 & 943 & 985 & 985 & 1015 & 888 \\
\hline Groups & 149 & 147 & 148 & 146 & 146 & 149 & 144 & 149 & 147 & 148 & 146 & 146 & 149 & 144 \\
\hline $\begin{array}{l}\text { Time fixed } \\
\text { effects } \\
\text { Country } \\
\text { fixed effects }\end{array}$ & $\begin{array}{l}\text { YES } \\
\text { YES } \\
\end{array}$ & $\begin{array}{l}\text { YES } \\
\text { YES }\end{array}$ & $\begin{array}{l}\text { YES } \\
\text { YES }\end{array}$ & YES & YES & YES & YES & YES & YES & YES & YES & YES & YES & YES \\
\hline
\end{tabular}

This table reports the main regression results of bank capital determinants and the effect of institutional variables using the Hausman-Taylor model for the period 2004-2014. The dependent variables are TCR; the total capital adequacy ratio (column 1 to 7 ) and EQTA; equity to total assets ratio (column 8 to 14). The independent variables are the following: PS is the measure of political stability. GC is a component of creditor's rights and measures the ease of getting credit. RI is another component of creditor's rights and it accounts for the ease of resolving insolvency, as well as liquidation. EF is the economic freedom index. FO is a measure of financial openness and includes financial and trade freedom. CPI is a corruption perception index. IFI is the institutional index we compute, it is the first principal component of PS, FO, EF, CPI. CRT is the creditor's rights index which is the principal component of two indexes: GC and RI. CONC is a measure of bank concentration calculated using the Herfindahl-Hirschman index on total assets. GDP measures the annual GDP Growth rate. REG is a score which measures the stringency of a country's capital regulatory jurisdiction. SIZE is calculated by the log of the total assets held by a bank. ROA is the return on average assets. ZSCORE is a measure of the risk of default. DEP INS is a dummy which takes the value of 1 for an explicit deposit insurance system and 0 for an implicit deposit insurance scheme. Islamic, Gov, and Listed are dummy variables for Islamic banks, government-owned banks, and listed banks respectively. All the ratios are expressed in percentages. Size is the natural logarithm of total assets which is in thousand U.S Dollars. Reported beneath each coefficient estimate is the t-statistic adjusted for clustering at the bank level. *,** and *** indicate statistical significance at the $10 \%, 5 \%$ and $1 \%$ levels, respectively. 
Table 8: The impact of institutional variables on bank capital - Underdeveloped Stock Markets

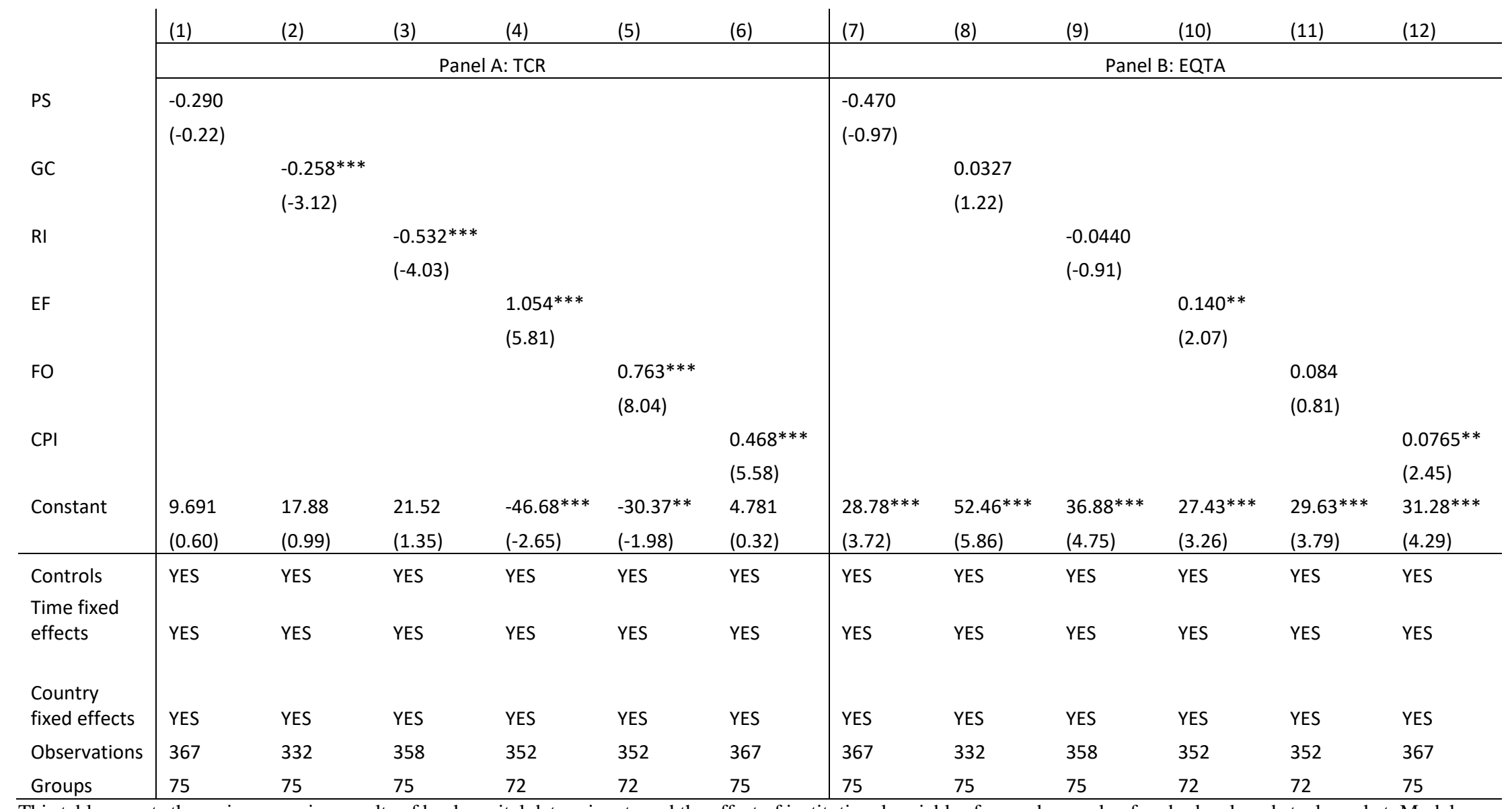

This table reports the main regression results of bank capital determinants and the effect of institutional variables for a sub-sample of underdeveloped stock market. Model

estimated using the Hausman-Taylor methodology for the period 2004-2014. The dependent variables are TCR; the total capital ratio (column 1 to 6) and EQTA; equity to total assets ratio (column 7 to 12). PS is the measure of political stability. GCREDIT is the first component of creditors' rights and measures the ease of getting credit. RI is the other component of the creditors' rights index and it accounts for the ease of resolving insolvency, as well as liquidation. EF is the economic freedom index. FO is a measure of financial openness and includes financial and trade freedom. CPI is a corruption perception index. Reported beneath each coefficient estimate is the t-statistic adjusted for clustering at the bank level. *,** and $* * *$ indicate statistical significance at the $10 \%, 5 \%$ and $1 \%$ levels, respectively. 
Table 9: The impact of institutional variables on bank capital - Developed Stock Markets

\begin{tabular}{|c|c|c|c|c|c|c|c|c|c|c|c|c|}
\hline & $(1)$ & $(2)$ & (3) & $(4)$ & $(5)$ & $(6)$ & $(7)$ & $(8)$ & (9) & $(10)$ & $(11)$ & $(12)$ \\
\hline & \multicolumn{6}{|c|}{ Panel A: TCR } & \multicolumn{6}{|c|}{ Panel B: EQTA } \\
\hline PS & $\begin{array}{l}-0.885 \\
(-0.85)\end{array}$ & & & & & & $\begin{array}{l}1.177^{* *} \\
(1.99)\end{array}$ & & & & & \\
\hline $\mathrm{GC}$ & & $\begin{array}{l}0.0737^{*} \\
(1.91)\end{array}$ & & & & & & $\begin{array}{l}0.0756^{* * *} \\
(3.97)\end{array}$ & & & & \\
\hline RI & & & $\begin{array}{l}-0.103 \\
(-0.92)\end{array}$ & & & & & & $\begin{array}{l}-0.0686 \\
(-1.21)\end{array}$ & & & \\
\hline $\mathrm{EF}$ & & & & $\begin{array}{l}0.0480 \\
(0.36)\end{array}$ & & & & & & $\begin{array}{l}0.0472 \\
(0.62)\end{array}$ & & \\
\hline FO & & & & & $\begin{array}{l}-0.00738 \\
(-0.09)\end{array}$ & & & & & & $\begin{array}{l}-0.0357 \\
(-0.78)\end{array}$ & \\
\hline $\mathrm{CPI}$ & & & & & & $\begin{array}{l}0.0506 \\
(0.77)\end{array}$ & & & & & & $\begin{array}{l}0.0348^{* * *} \\
(2.74)\end{array}$ \\
\hline Constant & $\begin{array}{l}68.66 * * * \\
(5.57)\end{array}$ & $\begin{array}{l}50.19 * * * \\
(3.66)\end{array}$ & $\begin{array}{l}55.33^{* * *} \\
(4.14) \\
\end{array}$ & $\begin{array}{l}67.63^{* * *} \\
(4.51)\end{array}$ & $\begin{array}{l}70.89 * * * \\
(5.53)\end{array}$ & $\begin{array}{l}69.59 * * * \\
(5.63)\end{array}$ & $\begin{array}{l}79.31 * * * \\
(8.93)\end{array}$ & $\begin{array}{l}103.8 * * * \\
(10.51)\end{array}$ & $\begin{array}{l}106.9 * * * \\
(10.83)\end{array}$ & $\begin{array}{l}80.32^{* * *} \\
(7.97)\end{array}$ & $\begin{array}{l}83.54^{* * *} \\
(9.19)\end{array}$ & $\begin{array}{l}82.39 * * * \\
(9.28)\end{array}$ \\
\hline $\begin{array}{l}\text { Controls } \\
\text { Time fixed }\end{array}$ & YES & YES & YES & YES & YES & YES & YES & YES & YES & YES & YES & YES \\
\hline $\begin{array}{l}\text { effects } \\
\text { Country }\end{array}$ & YES & YES & YES & YES & YES & YES & YES & YES & YES & YES & YES & YES \\
\hline fixed effects & YES & YES & YES & YES & YES & YES & YES & YES & YES & YES & YES & YES \\
\hline Observations & 409 & 353 & 364 & 394 & 394 & 409 & 409 & 353 & 364 & 394 & 394 & 409 \\
\hline Groups & 98 & 94 & 94 & 95 & 95 & 98 & 98 & 94 & 94 & 95 & 95 & 98 \\
\hline
\end{tabular}

This table reports the main regression results of bank capital determinants and the effect of institutional variables for a sub-sample of developed stock market. Model estimated using the Hausman-Taylor methodology for the period 2004-2014. The dependent variables are TCR; the total capital ratio (column 1 to 6) and EQTA; equity to total assets ratio (column 7 to 12). PS is the measure of political stability. GCREDIT is the first component of creditors' rights and measures the ease of getting credit. RI is the other component of the creditors' rights index and it accounts for the ease of resolving insolvency, as well as liquidation. EF is the economic freedom index. FO is a measure of financial openness and includes financial and trade freedom. CPI is a corruption perception index. Reported beneath each coefficient estimate is the t-statistic adjusted for clustering at the bank level. *, $* *$ and $* * *$ indicate statistical significance at the $10 \%, 5 \%$ and $1 \%$ levels, respectively. 
Table 10a: The impact of institutional variables on bank capital - - Stock Market Development further sub-sampling: Small versus large banks

\begin{tabular}{|c|c|c|c|c|c|c|c|c|}
\hline & \multicolumn{2}{|c|}{ High MKGDP } & \multicolumn{2}{|c|}{ Low MKGDP } & \multicolumn{2}{|c|}{ High MKGDP } & \multicolumn{2}{|c|}{ Low MKGDP } \\
\hline & \multicolumn{4}{|c|}{ Small Banks } & \multicolumn{4}{|c|}{ Large Banks } \\
\hline & TCR & EQTA & TCR & EQTA & TCR & EQTA & TCR & EQTA \\
\hline \multirow[t]{2}{*}{ PS } & -1.558 & $-9.757^{* * *}$ & -3.766 & 1.031 & -0.295 & -0.0448 & 1.238 & 0.0615 \\
\hline & $(-0.30)$ & $(-3.90)$ & $(-0.96)$ & (1.28) & $(-0.31)$ & $(-0.09)$ & $(1.00)$ & $(0.11)$ \\
\hline \multirow[t]{2}{*}{ GC } & 1.069 & 0.0371 & 0.451 & $\begin{array}{l}- \\
0.431 *\end{array}$ & $0.0828 * *$ & $0.0746 * * *$ & $-0.145^{* *}$ & 0.0215 \\
\hline & (1.48) & $(0.10)$ & $(0.34)$ & $(-1.90)$ & $(2.44)$ & $(4.24)$ & $(-1.98)$ & (0.69) \\
\hline \multirow[t]{2}{*}{$\mathrm{RI}$} & -0.0206 & $-1.118^{*}$ & 6.736 & 0.578 & -0.0965 & -0.0669 & $-0.414 * * *$ & -0.00349 \\
\hline & $(-0.02)$ & $(-1.91)$ & $(0.70)$ & $(0.27)$ & $(-0.99)$ & $(-1.31)$ & $(-3.59)$ & $(-0.07)$ \\
\hline \multirow[t]{2}{*}{$\mathrm{EF}$} & 1.168 & -0.113 & 1.631 & -0.238 & 0.0633 & $0.119^{*}$ & $0.705^{* * *}$ & 0.0323 \\
\hline & $(1.24)$ & $(-0.24)$ & $(0.62)$ & $(-0.43)$ & $(0.53)$ & (1.88) & $(4.32)$ & $(0.43)$ \\
\hline \multirow[t]{2}{*}{ FO } & -0.275 & $-0.483^{* *}$ & 0.201 & -0.141 & $0.128^{*}$ & $0.0897 * *$ & $0.654 * * *$ & $0.0918^{* *}$ \\
\hline & $(-0.62)$ & $(-2.32)$ & $(0.31)$ & $(-1.06)$ & (1.74) & (2.31) & (7.27) & (2.10) \\
\hline \multirow[t]{2}{*}{$\mathrm{CPI}$} & 0.314 & -0.0246 & 0.625 & -0.160 & $0.145^{* *}$ & $0.134 * * *$ & $0.437 * * *$ & $0.137 * * *$ \\
\hline & $(0.86)$ & $(-0.13)$ & $(0.93)$ & $(-1.16)$ & $(2.17)$ & (3.84) & (5.62) & $(3.85)$ \\
\hline
\end{tabular}

This Table shows whether small versus large banks behave differently when markets are developed or underdeveloped. Model

estimated using the Hausman-Taylor methodology for the period 2004-2014. Controls as well as year and country dummy variables are included for all the estimations but are not reported. The dependent variables are TCR; the total capital ratio (column 1 to 6 ) and EQTA; equity to total assets ratio (column 7 to 12). MKGDP is the market capital to GDP indicator of stock market development.

PS is the measure of political stability. GC is the first component of creditors' rights and measures the ease of getting credit. RI is the other component of the creditors' rights index and it accounts for the ease of resolving insolvency, as well as liquidation. EF is the economic freedom index. FO is a measure of financial openness and includes financial and trade freedom. CPI is a corruption perception index accounting for the level of perceived corruption in each country. Year and country dummy variables are included for all the estimations but are not reported. Reported beneath each coefficient estimate is the t-statistic adjusted for clustering at the bank level. *,** and $* * *$ indicate statistical significance at the $10 \%, 5 \%$ and $1 \%$ levels, respectively. 
Table 10b: The impact of institutional variables on bank capital - - Stock Market Development further sub-sampling: Non-listed versus listed banks

\begin{tabular}{|c|c|c|c|c|c|c|c|c|}
\hline & High I & KGDP & Low $N$ & GDP & High & KGDP & Low & GDP \\
\hline & & No & & & & & & \\
\hline & TCR & EQTA & TCR & EQTA & TCR & EQTA & TCR & EQTA \\
\hline PS & $-4.316^{*}$ & $-3.767^{* *}$ & $-5.970 *$ & -0.500 & 0.00202 & -0.291 & 2.424 & -0.175 \\
\hline & $(-1.77)$ & $(-2.44)$ & $(-1.79)$ & $(-0.65)$ & $(0.00)$ & $(-0.46)$ & (1.64) & $(-0.25)$ \\
\hline GC & $-0.237^{* *}$ & 0.0347 & $-0.429 *$ & 0.0131 & $0.112 * * *$ & $0.0668 * * *$ & -0.0877 & 0.0546 \\
\hline & $(-2.14)$ & $(0.54)$ & $(-1.87)$ & $(-0.25)$ & $(2.74)$ & (3.22) & $(-0.96)$ & (1.50) \\
\hline $\mathrm{RI}$ & -0.144 & -0.110 & $-2.889 * *$ & -0.276 & -0.0650 & -0.0244 & $-0.539 * * *$ & -0.0572 \\
\hline & $(-0.58)$ & $(-0.79)$ & $(-2.35)$ & $(-0.96)$ & $(-0.52)$ & $(-0.39)$ & $(-4.48)$ & $(-0.97)$ \\
\hline $\mathrm{EF}$ & -0.418 & -0.181 & $1.722^{* * *}$ & 0.161 & 0.183 & 0.115 & $0.914 * * *$ & $0.155^{*}$ \\
\hline & $(-1.26)$ & $(-0.81)$ & (2.65) & (1.06) & (1.26) & (1.51) & (5.05) & (1.71) \\
\hline FO & $-0.604 * * *$ & $-0.295^{* *}$ & $0.803^{* * *}$ & 0.0580 & $0.255^{* * *}$ & $0.114^{* *}$ & $0.832 * * *$ & $0.133^{* *}$ \\
\hline & $(-3.22)$ & $(-2.27)$ & (2.85) & $(0.87)$ & $(2.82)$ & (2.36) & (8.68) & (2.51) \\
\hline CPI & -0.249 & -0.0704 & 0.598 & 0.0239 & $0.164 * *$ & $0.130 * * *$ & $0.448 * * *$ & $0.114^{* * *}$ \\
\hline & $(-1.51)$ & $(-0.64)$ & (1.52) & $(0.26)$ & $(2.16)$ & (3.25) & (5.51) & $(2.82)$ \\
\hline
\end{tabular}

This Table shows whether non-listed versus listed banks behave differently when markets are developed or underdeveloped. Model

estimated using the Hausman-Taylor methodology for the period 2004-2014. Controls as well as year and country dummy variables are included for all the estimations but are not reported. The dependent variables are TCR; the total capital ratio (column 1 to 6) and EQTA; equity to total assets ratio (column 7 to 12). MKGDP is the market capital to GDP indicator of stock market development. PS is the measure of political stability. GC is the first component of creditors' rights and measures the ease of getting credit. RI is the other component of the creditors' rights index and it accounts for the ease of resolving insolvency, as well as liquidation. EF is the economic freedom index. FO is a measure of financial openness and includes financial and trade freedom. CPI is a corruption perception index accounting for the level of perceived corruption in each country. Year and country dummy variables are included for all the estimations but are not reported. Reported beneath each coefficient estimate is the t-statistic adjusted for clustering at the bank level. *, ** and $* * *$ indicate statistical significance at the $10 \%, 5 \%$ and $1 \%$ levels, respectively. 
Table 10c: The impact of institutional variables on bank capital - Stock Market Development further sub-sampling: Conventional versus Islamic banks

\begin{tabular}{|c|c|c|c|c|c|c|c|c|}
\hline & $\mathrm{High}$ & AKGDP & Low & KGDP & High N & GDP & Low & KGDP \\
\hline & & & anks & & & & & \\
\hline & TCR & EQTA & TCR & EQTA & TCR & EQTA & TCR & EQTA \\
\hline PS & -0.738 & $-1.162^{* *}$ & -0.119 & -0.414 & $23.87 * * *$ & -1.129 & -21.29 & -9.772 \\
\hline & $(-0.66)$ & $(-2.09)$ & $(-0.09)$ & $(-0.86)$ & (4.76) & $(-0.24)$ & $(-1.17)$ & $(-0.51)$ \\
\hline GC & $0.0831^{*}$ & $0.0576^{* * *}$ & $-0.267 * * *$ & 0.0268 & -0.0711 & 0.0435 & -0.466 & -0.162 \\
\hline & (1.95) & $(2.79)$ & $(-3.10)$ & (1.02) & $(-0.62)$ & $(0.50)$ & $(-0.92)$ & $(-0.32)$ \\
\hline $\mathrm{RI}$ & -0.0779 & -0.0802 & $-0.568^{* * *}$ & -0.0328 & 1.556 & $\overline{0} 0618$ & -2.228 & -1.023 \\
\hline & $(-0.70)$ & $(-1.47)$ & $(-3.82)$ & $(-0.63)$ & $(0.78)$ & $(-0.04)$ & $(-1.17)$ & $(-0.51)$ \\
\hline EF & 0.150 & 0.0973 & $1.101^{* * *}$ & $0.166^{* *}$ & -0.958 & 0.0671 & -0.641 & -0.294 \\
\hline & (1.12) & $(1.44)$ & (5.51) & (2.33) & $(-1.21)$ & $(0.11)$ & $(-1.17)$ & $(-0.51)$ \\
\hline FO & -0.00175 & 0.0222 & $0.761^{* * *}$ & $0.111^{* * *}$ & 0.511 & 0.0222 & -28.56 & -13.11 \\
\hline & $(-0.02)$ & $(0.08)$ & (7.51) & (2.95) & (1.46) & $(0.08)$ & $(-1.17)$ & $(-0.51)$ \\
\hline CPI & 0.0876 & -0.0519 & $0.472^{* * *}$ & $0.0858^{* * *}$ & 0.00433 & 0.0519 & -8.777 & -4.028 \\
\hline & $(1.25)$ & $(-0.15)$ & (5.13) & (2.62) & $(0.01)$ & $(-0.15)$ & $(-1.17)$ & $(-0.51)$ \\
\hline
\end{tabular}

This Table shows whether conventional versus Islamic banks behave differently when markets are developed or underdeveloped.

Model estimated using the Hausman-Taylor methodology for the period 2004-2014. Controls as well as year and country dummy

variables are included for all the estimations but are not reported. The dependent variables are TCR; the total capital ratio (column 1

to 6) and EQTA; equity to total assets ratio (column 7 to 12). MKGDP is the market capital to GDP indicator of stock market

development. PS is the measure of political stability. GC is the first component of creditors' rights and measures the ease of getting credit. RI is the other component of the creditors' rights index and it accounts for the ease of resolving insolvency, as well as

liquidation. EF is the economic freedom index. FO is a measure of financial openness and includes financial and trade freedom. CPI is a corruption perception index accounting for the level of perceived corruption in each country. Year and country dummy variables are included for all the estimations but are not reported. Reported beneath each coefficient estimate is the t-statistic adjusted for clustering at the bank level. *,** and $* * *$ indicate statistical significance at the $10 \%, 5 \%$ and $1 \%$ levels, respectively 
Table 11: The impact of institutional variables on bank capital - Large/Small

\begin{tabular}{|c|c|c|c|c|c|c|c|c|c|c|c|c|}
\hline \multirow[b]{3}{*}{ Large ( $\beta 1)$} & (1) & (2) & (3) & (4) & (5) & (6) & (7) & (8) & (9) & $(10)$ & (11) & $(12)$ \\
\hline & \multicolumn{6}{|c|}{ Panel A: TCR } & \multicolumn{6}{|c|}{ Panel B: EQTA } \\
\hline & $\begin{array}{l}-3.471^{* * *} \\
(-3.87)\end{array}$ & $\begin{array}{l}-5.491 * * * \\
(-4.31)\end{array}$ & $\begin{array}{l}-14.53^{* * *} \\
(-4.45)\end{array}$ & $\begin{array}{l}3.497 \\
(0.62)\end{array}$ & $\begin{array}{l}-12.36 \\
(-1.47)\end{array}$ & $\begin{array}{l}-7.505^{* * *} \\
(-3.27)\end{array}$ & $\begin{array}{l}-1.357^{* * *} \\
(-3.11)\end{array}$ & $\begin{array}{l}-1.495^{* *} \\
(-2.49)\end{array}$ & $\begin{array}{l}-2.286 \\
(-1.46)\end{array}$ & $\begin{array}{l}-7.272^{* *} \\
(-2.52)\end{array}$ & $\begin{array}{l}-2.237 \\
(-0.53)\end{array}$ & $\begin{array}{l}-0.335 \\
(-0.29)\end{array}$ \\
\hline PS ( $\beta 2)$ & $\begin{array}{l}-1.020 \\
(-1.22)\end{array}$ & & & & & & $\begin{array}{l}-0.418 \\
(-1.04)\end{array}$ & & & & & \\
\hline PS*Large ( $\beta 3)$ & $\begin{array}{l}0.296 \\
(0.44)\end{array}$ & & & & & & $\begin{array}{l}-0.742^{* *} \\
(-2.25)\end{array}$ & & & & & \\
\hline GC*Large ( $\beta 3)$ & & $\begin{array}{l}-0.143^{* * *} \\
(-3.51)\end{array}$ & & & & & & $\begin{array}{l}-0.0146 \\
(-0.76)\end{array}$ & & & & \\
\hline $\mathrm{RI}(\beta 2)$ & & & $\begin{array}{l}0.327^{* * *} \\
(3.22)\end{array}$ & & & & & & $\begin{array}{l}0.0394 \\
(0.81)\end{array}$ & & & \\
\hline $\mathrm{RI} *$ Large $(\beta 3)$ & & & $\begin{array}{l}-0.535^{* * *} \\
(-4.47)\end{array}$ & & & & & & $\begin{array}{l}-0.0759 \\
(-1.34)\end{array}$ & & & \\
\hline FO*Large ( $\beta 3)$ & & & & $\begin{array}{l}0.522^{* * *} \\
(5.70)\end{array}$ & & & & & & $\begin{array}{l}-0.0790^{*} \\
(-1.69)\end{array}$ & & \\
\hline$E F(\beta 2)$ & & & & & $\begin{array}{l}0.142 \\
(1.05)\end{array}$ & & & & & & $\begin{array}{l}0.0214 \\
(0.32)\end{array}$ & \\
\hline EF*Large ( $\beta 3)$ & & & & & $\begin{array}{l}0.322^{* *} \\
(2.09)\end{array}$ & & & & & & $\begin{array}{l}0.0305 \\
(0.40)\end{array}$ & \\
\hline
\end{tabular}




\begin{tabular}{|c|c|c|c|c|c|c|c|c|c|c|c|c|}
\hline \multirow[t]{2}{*}{$\mathrm{CPI}(\beta 2)$} & & & & & & $0.0948 *$ & & & & & & -0.0132 \\
\hline & & & & & & $(1.80)$ & & & & & & $(-0.50)$ \\
\hline \multirow{2}{*}{ CPI*Large $(\beta 3)$} & & & & & & -0.000401 & & & & & & 0.00604 \\
\hline & & & & & & $(-0.01)$ & & & & & & $(0.20)$ \\
\hline \multirow[t]{2}{*}{ Constant } & $17.31^{* * *}$ & $27.54 * * *$ & $35.39 * * *$ & $-11.80 *$ & -0.543 & $18.75^{* * *}$ & $7.742 * * *$ & $9.183^{* * *}$ & $11.61 * * *$ & $14.28 * * *$ & 7.026 & $8.498 * * *$ \\
\hline & $(7.31)$ & $(9.81)$ & $(8.57)$ & $(-1.86)$ & $(-0.06)$ & $(5.72)$ & $(5.38)$ & $(5.69)$ & $(5.40)$ & $(4.27)$ & $(1.43)$ & $(4.64)$ \\
\hline Controls & YES & YES & YES & YES & YES & YES & YES & YES & YES & YES & YES & YES \\
\hline Time fixed effects & YES & YES & YES & YES & YES & YES & YES & YES & YES & YES & YES & YES \\
\hline Country fixed effects & YES & YES & YES & YES & YES & YES & YES & YES & YES & YES & YES & YES \\
\hline Observations & 1015 & 894 & 943 & 985 & 985 & 1015 & 1015 & 894 & 943 & 985 & 985 & 1015 \\
\hline Groups & 149 & 147 & 148 & 146 & 146 & 149 & 149 & 147 & 148 & 146 & 146 & 149 \\
\hline Wald P-value & 0.23 & 0.00 & 0.00 & 0.00 & 0.00 & 0.07 & 0.00 & 0.69 & 0.26 & 0.46 & 0.18 & 0.62 \\
\hline$(\beta 2)+(\beta 3)$ & -0.72 & -0.10 & -0.21 & 0.42 & 0.46 & 0.19 & -1.159 & 0.00 & -0.04 & 0.02 & 0.05 & -0.03 \\
\hline
\end{tabular}

This Table shows whether institutional variables influence differently capital ratios of large banks versus small banks. Model estimated using the Hausman-Taylor methodology for the period 2004-2014. The dependent variables are TCR; the total capital ratio (column 1 to 6) and EQTA; equity to total assets ratio (column 7 to 12). Large is a dummy which takes the value of 1 for a large bank and zero for a small one. PS is the measure of political stability. GC is the first component of creditors' rights and measures the ease of getting credit. RI is the other component of the creditors' rights index and it accounts for the ease of resolving insolvency, as well as liquidation. EF is the economic freedom index. FO is a measure of financial openness and includes financial and trade freedom. CPI is a corruption perception index accounting for the level of perceived corruption in each country. Reported beneath each coefficient estimate is the t-statistic adjusted for clustering at the bank level. *, ** and *** indicate statistical significance at the $10 \%, 5 \%$ and $1 \%$ levels, respectively. 
Table 12: The impact of institutional variables on bank capital - Government-owned/Non-Government-Owned

\begin{tabular}{|c|c|c|c|c|c|c|c|c|c|c|c|c|}
\hline \multirow[b]{3}{*}{ Gov (B1) } & (1) & (2) & (3) & (4) & (5) & (6) & (7) & (8) & (9) & (10) & (11) & (12) \\
\hline & \multicolumn{6}{|c|}{ Panel A: TCR } & \multicolumn{6}{|c|}{ Panel B: EQTA } \\
\hline & $\begin{array}{l}4.205^{* *} \\
(2.35)\end{array}$ & $\begin{array}{l}1.828 \\
(0.87)\end{array}$ & $\begin{array}{l}7.585^{*} \\
(1.86)\end{array}$ & $\begin{array}{l}5.713 \\
(1.16)\end{array}$ & $\begin{array}{l}-2.040 \\
(-0.26)\end{array}$ & $\begin{array}{l}6.702^{*} \\
(1.76)\end{array}$ & $\begin{array}{l}3.925^{* * *} \\
(3.05)\end{array}$ & $\begin{array}{l}4.383^{* * *} \\
(2.70)\end{array}$ & $\begin{array}{l}2.597 \\
(1.11)\end{array}$ & $\begin{array}{l}3.939 \\
(1.51)\end{array}$ & $\begin{array}{l}7.014^{*} \\
(1.80)\end{array}$ & $\begin{array}{l}5.856^{* * *} \\
(2.79)\end{array}$ \\
\hline PS ( $(\beta 2)$ & $\begin{array}{l}0.361 \\
(0.59)\end{array}$ & & & & & & $\begin{array}{l}-0.313 \\
(-1.12)\end{array}$ & & & & & \\
\hline PS*Gov ( $\beta 3)$ & $\begin{array}{l}-1.480 \\
(-1.56)\end{array}$ & - & & & & & $\begin{array}{l}-0.154 \\
(-0.32)\end{array}$ & & & & & \\
\hline $\mathrm{GC}(\beta 2)$ & & $\begin{array}{l}0.0966^{* * *} \\
(-5.26)\end{array}$ & & & & & & $\begin{array}{l}0.0182^{* *} \\
(2.39)\end{array}$ & & & & \\
\hline GC*Gov ( $\beta 3)$ & & $\begin{array}{l}0.0418 \\
(1.51)\end{array}$ & & & & & & $\begin{array}{l}-0.000575 \\
(-0.05)\end{array}$ & & & & \\
\hline RI ( $\beta 2)$ & & & $\begin{array}{l}-0.220^{* * *} \\
(-3.23)\end{array}$ & & & & & & $\begin{array}{l}-0.0524^{*} \\
(-1.83)\end{array}$ & & & \\
\hline $\mathrm{RI}^{*} \operatorname{Gov}(\beta 3)$ & & & $\begin{array}{l}-0.117 \\
(-1.13)\end{array}$ & & & & & & $\begin{array}{l}0.0370 \\
(0.71)\end{array}$ & & & \\
\hline $\mathrm{FO}(\beta 2)$ & & & & $\begin{array}{l}0.434^{* * *} \\
(9.50)\end{array}$ & & & & & & $\begin{array}{l}0.00217 \\
(0.10)\end{array}$ & & \\
\hline FO*Gov ( $\beta 3)$ & & & & $\begin{array}{l}-0.0209 \\
(-0.30)\end{array}$ & & & & & & $\begin{array}{l}0.00232 \\
(0.07)\end{array}$ & & \\
\hline $\mathrm{EF}(\beta 2)$ & & & & & $\begin{array}{l}0.439^{* * *} \\
(5.46)\end{array}$ & & & & & & $\begin{array}{l}0.0420 \\
(1.14)\end{array}$ & \\
\hline EF*Gov ( $\beta 3)$ & & & & & $\begin{array}{l}0.0943 \\
(0.81)\end{array}$ & & & & & & $\begin{array}{l}-0.0443 \\
(-0.79)\end{array}$ & \\
\hline $\mathrm{CPI}(\beta 2)$ & & & & & & $0.154^{* * *}$ & & & & & & $0.0424 * *$ \\
\hline
\end{tabular}




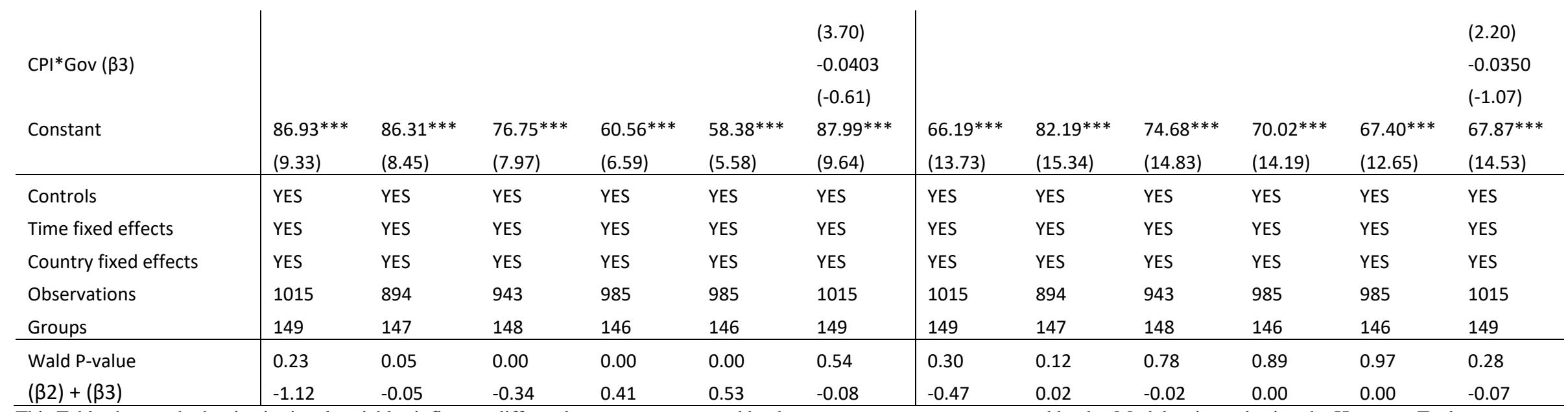

This Table shows whether institutional variables influence differently government-owned banks versus non-government-owned banks. Model estimated using the Hausman-Taylor methodology for the period 2004-2014. The dependent variables are TCR; the total capital ratio (column 1 to 6) and EQTA; equity to total assets ratio (column 7 to 12). Gov is a dummy which takes the value of 1 for a government-owned bank and zero otherwise. PS is the measure of political stability. GC is the first component of creditors' rights and measures the ease of getting credit. RI is the other component of the creditors' rights index and it accounts for the ease of resolving insolvency, as well as liquidation. EF is the economic freedom index. FO is a measure of financial openness and includes financial and trade freedom. CPI is a corruption perception index accounting for the level of perceived corruption in each country. Reported beneath each coefficient estimate is the t-statistic adjusted for clustering at the bank level. *, ** and $* * *$ indicate statistical significance at the $10 \%, 5 \%$ and $1 \%$ levels, respectively. 
Table 13: The impact of institutional variables on bank capital - Islamic/Conventional

\begin{tabular}{|c|c|c|c|c|c|c|c|c|c|c|c|c|}
\hline \multirow[b]{3}{*}{ Islamic ( $\beta 1)$} & (1) & (2) & (3) & (4) & (5) & (6) & (7) & (8) & (9) & (10) & (11) & $(12)$ \\
\hline & \multicolumn{6}{|c|}{ Panel A: TCR } & \multicolumn{6}{|c|}{ Panel B: EQTA } \\
\hline & $\begin{array}{l}-1.036 \\
(-0.55)\end{array}$ & $\begin{array}{l}-5.657^{* *} \\
(-2.30)\end{array}$ & $\begin{array}{l}-3.977 \\
(-0.86)\end{array}$ & $\begin{array}{l}-25.70 * * * \\
(-3.23)\end{array}$ & $\begin{array}{l}-7.318 \\
(-0.79)\end{array}$ & $\begin{array}{l}-1.810 \\
(-0.38)\end{array}$ & $\begin{array}{l}-0.129 \\
(-0.09)\end{array}$ & $\begin{array}{l}-0.595 \\
(-0.33)\end{array}$ & $\begin{array}{l}2.798 \\
(0.98)\end{array}$ & $\begin{array}{l}-11.03^{* * *} \\
(-2.61)\end{array}$ & $\begin{array}{l}-2.674 \\
(-0.58)\end{array}$ & $\begin{array}{l}-4.364^{*} \\
(-1.66)\end{array}$ \\
\hline PS (B2) & $\begin{array}{l}-0.205 \\
(-0.35)\end{array}$ & & & & & & $\begin{array}{l}-0.426 \\
(-1.60)\end{array}$ & & & & & \\
\hline PS*Islamic (ß3) & $\begin{array}{l}2.371^{*} \\
(1.85)\end{array}$ & & & & & & $\begin{array}{l}0.794 \\
(1.16)\end{array}$ & & & & & \\
\hline $\mathrm{GC}(\beta 2)$ & & $\begin{array}{l}0.0964^{* * *} \\
(-5.50)\end{array}$ & & & & & & $\begin{array}{l}0.0180^{* *} \\
(2.47)\end{array}$ & & & & \\
\hline GC*Islamic ( $\beta 3)$ & & $\begin{array}{l}0.111^{* * *} \\
(2.79)\end{array}$ & & & & & & $\begin{array}{l}0.00140 \\
(0.08)\end{array}$ & & & & \\
\hline RI ( $\beta 2)$ & & & $\begin{array}{l}-0.237 * * * \\
(-3.52)\end{array}$ & & & & & & $\begin{array}{l}-0.0442 \\
(-1.57)\end{array}$ & & & \\
\hline RI*Islamic ( $\beta 3)$ & & & $\begin{array}{l}0.0757 \\
(0.63)\end{array}$ & & & & & & $\begin{array}{l}-0.0880 \\
(-1.32)\end{array}$ & & & \\
\hline FO $(\beta 2)$ & & & & $\begin{array}{l}0.409^{* * *} \\
(9.49)\end{array}$ & & & & & & $\begin{array}{l}-0.00643 \\
(-0.32)\end{array}$ & & \\
\hline FO*Islamic ( $\beta 3)$ & & & & $\begin{array}{l}0.373^{* * *} \\
(3.19)\end{array}$ & & & & & & $\begin{array}{l}0.162^{* * *} \\
(2.69)\end{array}$ & & \\
\hline $\mathrm{EF}(\beta 2)$ & & & & & $\begin{array}{l}0.449 * * * \\
(5.69)\end{array}$ & & & & & & $\begin{array}{l}0.0243 \\
(0.67)\end{array}$ & \\
\hline EF*Islamic (ß3) & & & & & $\begin{array}{l}0.0937 \\
(0.69)\end{array}$ & & & & & & $\begin{array}{l}0.0356 \\
(0.54)\end{array}$ & \\
\hline CPI ( $\beta 2)$ & & & & & & $\begin{array}{l}0.142^{* * *} \\
(3.64)\end{array}$ & & & & & & $\begin{array}{l}0.0224 \\
(1.25)\end{array}$ \\
\hline CPI*Islamic ( $\beta 3)$ & & & & & & 0.0109 & & & & & & $0.0785 *$ \\
\hline
\end{tabular}




\begin{tabular}{|c|c|c|c|c|c|c|c|c|c|c|c|c|}
\hline Constant & $\begin{array}{l}86.98^{* * *} \\
(9.34)\end{array}$ & $\begin{array}{l}92.83^{* * *} \\
(8.93)\end{array}$ & $\begin{array}{l}77.27^{* * *} \\
(7.98)\end{array}$ & $\begin{array}{l}62.91 * * * \\
(6.87)\end{array}$ & $\begin{array}{l}57.52^{* * *} \\
(5.42)\end{array}$ & $\begin{array}{l}(0.13) \\
88.09 * * * \\
(9.64)\end{array}$ & $\begin{array}{l}66.15^{* * *} \\
(13.79)\end{array}$ & $\begin{array}{l}82.56 * * * \\
(15.33)\end{array}$ & $\begin{array}{l}74.32 * * * \\
(14.65)\end{array}$ & $\begin{array}{l}71.25^{* * *} \\
(14.43)\end{array}$ & $\begin{array}{l}68.55^{* * *} \\
(12.60)\end{array}$ & $\begin{array}{l}(1.87) \\
69.39 * * * \\
(14.89)\end{array}$ \\
\hline Controls & YES & YES & YES & YES & YES & YES & YES & YES & YES & YES & YES & YES \\
\hline Time fixed effects & YES & YES & YES & YES & YES & YES & YES & YES & YES & YES & YES & YES \\
\hline Country fixed effects & YES & YES & YES & YES & YES & YES & YES & YES & YES & YES & YES & YES \\
\hline Observations & 1015 & 894 & 943 & 985 & 985 & 1015 & 1015 & 894 & 943 & 985 & 985 & 1015 \\
\hline Groups & 149 & 147 & 148 & 146 & 146 & 149 & 149 & 147 & 148 & 146 & 146 & 149 \\
\hline Wald P-value & 0.09 & 0.72 & 0.22 & 0.00 & 0.00 & 0.90 & 0.58 & 0.26 & 0.06 & 0.01 & 0.34 & 0.06 \\
\hline$(\beta 2)+(\beta 3)$ & 2.166 & 0.01 & -0.16 & 0.78 & 0.54 & 0.02 & 0.37 & 0.02 & -0.13 & 0.16 & 0.06 & 0.16 \\
\hline
\end{tabular}

This Table shows whether institutional variables influence differently Islamic versus conventional banks. Model estimated using the Hausman-Taylor methodology for the period 2004-2014. The dependent variables are TCR; the total capital ratio (column 1 to 6) and EQTA; equity to total assets ratio (column 7 to 12). Gov is a dummy which takes the value of 1 for a government-owned bank and zero otherwise. PS is the measure of political stability. GC is the first component of creditors' rights and measures the ease of getting credit. $\mathrm{RI}$ is the other component of the creditors' rights index and it accounts for the ease of resolving insolvency, as well as liquidation. EF is the economic freedom index. FO is a measure of financial openness and includes financial and trade freedom. CPI is a corruption perception index accounting for the level of perceived corruption in each country. Reported beneath each coefficient estimate is the t-statistic adjusted for clustering at the bank level. *,** and $* * *$ indicate statistical significance at the $10 \%, 5 \%$ and $1 \%$ levels, respectively. 
Table 14: The impact of institutional variables on bank capital - Listed/Non-listed

\begin{tabular}{|c|c|c|c|c|c|c|c|c|c|c|c|c|}
\hline \multirow[b]{3}{*}{ Listed ( $\beta 1)$} & (1) & (2) & (3) & (4) & (5) & (6) & (7) & (8) & (9) & (10) & (11) & (12) \\
\hline & \multicolumn{6}{|c|}{ Panel A: TCR } & \multicolumn{6}{|c|}{ Panel B: EQTA } \\
\hline & $\begin{array}{l}4.852^{* * *} \\
(2.64)\end{array}$ & $\begin{array}{l}-4.734^{* *} \\
(-2.34)\end{array}$ & $\begin{array}{l}-2.891 \\
(-0.77)\end{array}$ & $\begin{array}{l}-8.941 * \\
(-1.72)\end{array}$ & $\begin{array}{l}-11.49 \\
(-1.32)\end{array}$ & $\begin{array}{l}12.35^{* * *} \\
(3.35)\end{array}$ & $\begin{array}{l}2.959^{* *} \\
(2.32)\end{array}$ & $\begin{array}{l}2.717^{*} \\
(1.68)\end{array}$ & $\begin{array}{l}6.274^{* * *} \\
(2.95)\end{array}$ & $\begin{array}{l}-0.657 \\
(-0.24)\end{array}$ & $\begin{array}{l}3.905 \\
(0.89)\end{array}$ & $\begin{array}{l}-0.398 \\
(-0.19)\end{array}$ \\
\hline PS ( $\beta 2)$ & $\begin{array}{l}-0.159 \\
(-0.21)\end{array}$ & & & & & & $\begin{array}{l}-0.996^{* * *} \\
(-2.79)\end{array}$ & & & & & \\
\hline PS*Listed ( $\beta 3$ ) & $\begin{array}{l}0.317 \\
(0.37)\end{array}$ & & & & & & $\begin{array}{l}1.094^{* * *} \\
(2.62)\end{array}$ & & & & & \\
\hline GC*Listed ( $\beta 3)$ & & $\begin{array}{l}0.211^{* * *} \\
(8.71)\end{array}$ & & & & & & $\begin{array}{l}0.00535 \\
(0.51)\end{array}$ & & & & \\
\hline RI ( $\beta 2)$ & & & $\begin{array}{l}-0.371^{* *} \\
(-3.77)\end{array}$ & & & & & & $\begin{array}{l}0.0343 \\
(0.77)\end{array}$ & & & \\
\hline RI*Listed ( $\beta 3)$ & & & $\begin{array}{l}0.179^{*} \\
(1.93)\end{array}$ & & & & & & $\begin{array}{l}-0.106^{* *} \\
(-2.40)\end{array}$ & & & \\
\hline FO*Listed ( $\beta 3)$ & & & & $\begin{array}{l}0.200^{* * *} \\
(2.75)\end{array}$ & & & & & & $\begin{array}{l}0.0493 \\
(1.39)\end{array}$ & & \\
\hline$E F(\beta 2)$ & & & & & $\begin{array}{l}0.252^{*} \\
(1.88)\end{array}$ & & & & & & $\begin{array}{l}0.0477 \\
(0.74)\end{array}$ & \\
\hline EF*Listed ( $\beta 3)$ & & & & & $\begin{array}{l}0.248^{*} \\
(1.89)\end{array}$ & & & & & & $\begin{array}{l}-0.0205 \\
(-0.32)\end{array}$ & \\
\hline CPI ( $\beta 2)$ & & & & & & $\begin{array}{l}0.260^{* * *} \\
(4.10)\end{array}$ & & & & & & $\begin{array}{l}-0.0182 \\
(-0.59)\end{array}$ \\
\hline CPI*Listed ( $\beta 3)$ & & & & & & $-0.155^{* *}$ & & & & & & $0.0671^{* *}$ \\
\hline
\end{tabular}




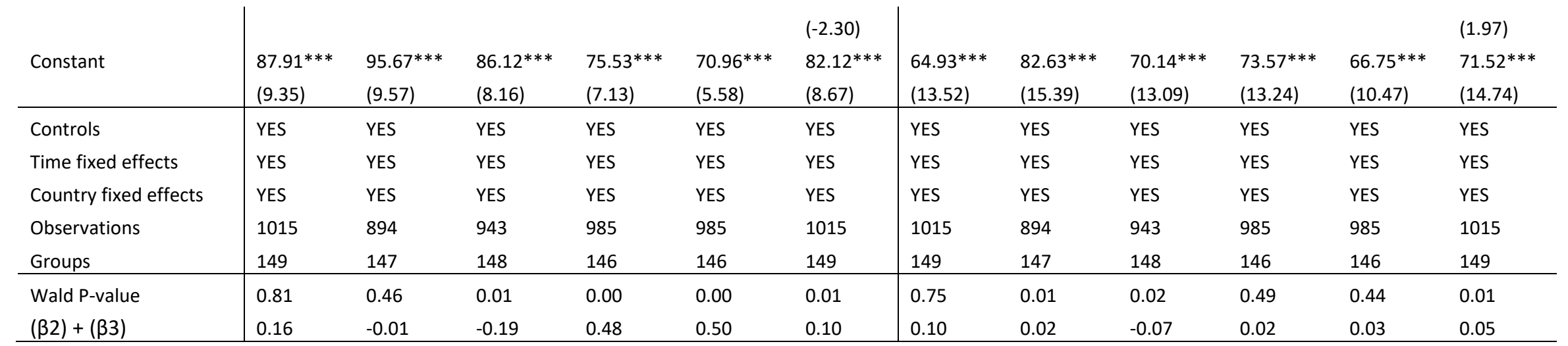

This Table shows whether institutional variables influence differently listed versus non-listed banks. Model estimated using the Hausman-Taylor methodology for the period 20042014. The dependent variables are TCR; the total capital ratio (column 1 to 6) and EQTA; equity to total assets ratio (column 7 to 12 ). Listed is a dummy which takes the value of 1 if the bank is listed on a stock exchange and zero otherwise. PS is the measure of political stability. GC is the first component of creditors' rights and measures the ease of getting credit. RI is the other component of the creditors' rights index and it accounts for the ease of resolving insolvency, as well as liquidation. EF is the economic freedom index. FO is a measure of financial openness and includes financial and trade freedom. CPI is a corruption perception index accounting for the level of perceived corruption in each country. Reported beneath each coefficient estimate is the t-statistic adjusted for clustering at the bank level. *,** and *** indicate statistical significance at the $10 \%, 5 \%$ and $1 \%$ levels, respectively. 


\section{Appendix}

Table 1: The impact of institutional variables on bank capital - Robustness Check: Tier1

\begin{tabular}{|c|c|c|c|c|c|c|c|}
\hline & (1) & (2) & (3) & (4) & (5) & (6) & (7) \\
\hline & \multicolumn{7}{|c|}{ TIER1 } \\
\hline PS & $\begin{array}{l}1.017^{*} \\
(1.77)\end{array}$ & & & & & & \\
\hline $\mathrm{GC}$ & & $\begin{array}{l}-0.0370^{* *} \\
(-2.36)\end{array}$ & & & & & \\
\hline RI & & & $\begin{array}{l}-0.0867 \\
(-1.28)\end{array}$ & & & & \\
\hline EF & & & & $\begin{array}{l}0.250^{* * *} \\
(3.25)\end{array}$ & & & \\
\hline FO & & & & & $\begin{array}{l}0.144^{* * *} \\
(3.35)\end{array}$ & & \\
\hline CPI & & & & & & $\begin{array}{l}0.0581^{*} \\
(1.71)\end{array}$ & \\
\hline II & & & & & & & $\begin{array}{l}3.127^{* * *} \\
(4.18)\end{array}$ \\
\hline CRT & & & & & & & $\begin{array}{l}-1.485^{* * *} \\
(-3.43)\end{array}$ \\
\hline CONC & $\begin{array}{l}-2.464 \\
(-0.44)\end{array}$ & $\begin{array}{l}1.821 \\
(0.24)\end{array}$ & $\begin{array}{l}2.579 \\
(0.35)\end{array}$ & $\begin{array}{l}2.182 \\
(0.38)\end{array}$ & $\begin{array}{l}-6.601 \\
(-1.14)\end{array}$ & $\begin{array}{l}-1.812 \\
(-0.32)\end{array}$ & $\begin{array}{l}5.098 \\
(0.69)\end{array}$ \\
\hline GDP & $\begin{array}{l}-0.0452 \\
(-1.10)\end{array}$ & $\begin{array}{l}-0.0208 \\
(-0.45)\end{array}$ & $\begin{array}{l}-0.0214 \\
(-0.47)\end{array}$ & $\begin{array}{l}-0.0323 \\
(-0.78)\end{array}$ & $\begin{array}{l}-0.0389 \\
(-0.94)\end{array}$ & $\begin{array}{l}-0.0520 \\
(-1.25)\end{array}$ & $\begin{array}{l}-0.0253 \\
(-0.55)\end{array}$ \\
\hline REG & $\begin{array}{l}-0.309 * \\
(-1.71)\end{array}$ & $\begin{array}{l}-0.187 \\
(-0.97)\end{array}$ & $\begin{array}{l}-0.289 \\
(-1.41)\end{array}$ & $\begin{array}{l}-0.116 \\
(-0.62)\end{array}$ & $\begin{array}{l}-0.166 \\
(-0.91)\end{array}$ & $\begin{array}{l}-0.295 \\
(-1.64)\end{array}$ & $\begin{array}{l}-0.117 \\
(-0.60)\end{array}$ \\
\hline SIZE & $\begin{array}{l}-5.107^{* * *} \\
(-9.00)\end{array}$ & $\begin{array}{l}-4.010^{* * *} \\
(-6.24)\end{array}$ & $\begin{array}{l}-4.001 * * * \\
(-6.50)\end{array}$ & $\begin{array}{l}-5.340 * * * \\
(-9.38)\end{array}$ & $\begin{array}{l}-5.566 * * * \\
(-9.73)\end{array}$ & $\begin{array}{l}-5.535 * * * \\
(-9.60)\end{array}$ & $\begin{array}{l}-3.814 * * * \\
(-6.02)\end{array}$ \\
\hline
\end{tabular}




\begin{tabular}{|c|c|c|c|c|c|c|c|}
\hline \multirow[t]{2}{*}{ ROA } & 0.123 & 0.207 & 0.287 & 0.135 & 0.163 & 0.184 & 0.248 \\
\hline & $(0.57)$ & $(0.84)$ & $(1.21)$ & $(0.63)$ & $(0.76)$ & $(0.85)$ & $(1.02)$ \\
\hline \multirow[t]{2}{*}{ ZSCORE } & 0.169 & 0.217 & 0.165 & 0.119 & 0.165 & 0.138 & 0.172 \\
\hline & $(1.06)$ & (1.30) & $(1.02)$ & $(0.74)$ & (1.04) & $(0.87)$ & (1.04) \\
\hline \multirow[t]{2}{*}{ DEP_INS } & 1.538 & 0.341 & 4.212 & 1.540 & 3.162 & 1.593 & 3.812 \\
\hline & $(0.20)$ & $(0.05)$ & $(0.59)$ & $(0.19)$ & $(0.39)$ & $(0.20)$ & $(0.58)$ \\
\hline \multirow[t]{2}{*}{ Islamic } & 1.544 & 1.477 & 1.408 & 1.388 & 1.342 & 1.352 & 1.401 \\
\hline & $(0.79)$ & $(0.86)$ & $(0.80)$ & $(0.68)$ & $(0.64)$ & $(0.65)$ & $(0.83)$ \\
\hline \multirow[t]{2}{*}{ Gov } & $4.175^{* *}$ & $3.143^{*}$ & $3.180 *$ & $4.405^{* *}$ & $4.712^{* *}$ & $4.617^{* *}$ & $3.043^{*}$ \\
\hline & (2.19) & $(1.85)$ & $(1.84)$ & $(2.23)$ & $(2.33)$ & $(2.30)$ & $(1.84)$ \\
\hline \multirow[t]{2}{*}{ Listed } & $3.618^{*}$ & 2.430 & 2.445 & $3.826^{* *}$ & $3.939 * *$ & $3.985^{* *}$ & 2.353 \\
\hline & $(1.94)$ & $(1.46)$ & $(1.44)$ & (1.98) & (1.99) & $(2.03)$ & $(1.45)$ \\
\hline \multirow[t]{2}{*}{ Constant } & $91.69 * * *$ & $77.42 * * *$ & $77.32 * * *$ & $80.38 * * *$ & $91.48 * * *$ & $97.22 * * *$ & $73.59 * * *$ \\
\hline & $(10.07)$ & $(7.70)$ & $(7.97)$ & $(7.68)$ & $(9.83)$ & $(10.75)$ & $(7.40)$ \\
\hline Time fixed effects & YES & YES & YES & YES & YES & YES & YES \\
\hline Country fixed effects & YES & YES & YES & YES & YES & YES & YES \\
\hline Observations & 767 & 679 & 709 & 753 & 753 & 767 & 675 \\
\hline Groups & 127 & 126 & 126 & 125 & 125 & 127 & 124 \\
\hline
\end{tabular}

Hausman-Taylor model for the period 2004-2014. The dependent variable is the Tier1 capital ratio. The independent variables are the following: PS is the measure of political stability. GC is a component of creditor's rights and measures the ease of getting credit. $\mathrm{RI}$ is another component of creditor's rights and it accounts for the ease of resolving insolvency, as well as liquidation. EF is the economic freedom index. FO is a measure of financial openness and includes financial and trade freedom. CPI is a corruption perception index. IFI is the institutional index we compute, it is the first principal component of PS, FO, EF, CPI. CRT is the creditor's rights index which is the principal component of two indexes: GC and RI. CONC is a measure of bank concentration calculated using the Herfindahl-Hirschman index on total assets. GDP measures the annual GDP Growth rate. REG is a score which measures the stringency of a country's capital regulatory jurisdiction. SIZE is calculated by the log of the total assets held by a

bank. ROA is the return on average assets. ZSCORE is a measure of the risk of default. DEP INS is a dummy which takes the value of 1 for an explicit deposit insurance system and 0 for an implicit deposit insurance scheme. Islamic, Gov, and Listed are dummy variables for Islamic banks, government-owned banks, and listed banks respectively. All the ratios are expressed in percentages. Size is the natural logarithm of total assets which is in thousand U.S Dollars. Reported beneath each coefficient estimate is the tstatistic adjusted for clustering at the bank level. *,** and $* * *$ indicate statistical significance at the $10 \%, 5 \%$ and $1 \%$ levels, respectively. 
Table 2: The impact of institutional variables on bank capital - Robustness Check: Capital Buffer

\begin{tabular}{|c|c|c|c|c|c|c|c|}
\hline & (1) & (2) & (3) & (4) & (5) & (6) & (7) \\
\hline & \multicolumn{7}{|c|}{ KBUFF } \\
\hline PS & $\begin{array}{l}0.474 \\
(0.72)\end{array}$ & & & & & & \\
\hline \multirow[t]{2}{*}{$\mathrm{GC}$} & & $-0.0928 * * *$ & & & & & \\
\hline & & $(-4.48)$ & & & & & \\
\hline \multirow[t]{2}{*}{ RI } & & & $-0.255^{* * *}$ & & & & \\
\hline & & & $(-3.37)$ & & & & \\
\hline \multirow[t]{2}{*}{$\mathrm{EF}$} & & & & $0.319 * * *$ & & & \\
\hline & & & & (6.43) & & & \\
\hline \multirow[t]{2}{*}{ FO } & & & & & $0.349 * * *$ & & \\
\hline & & & & & $(4.08)$ & & \\
\hline \multirow{2}{*}{ CPI } & & & & & & 0.0411 & \\
\hline & & & & & & $(0.98)$ & \\
\hline \multirow[t]{2}{*}{ ॥ } & & & & & & & $4.407 * * *$ \\
\hline & & & & & & & (5.41) \\
\hline \multirow[t]{2}{*}{ CRT } & & & & & & & $-3.054 * * *$ \\
\hline & & & & & & & $(-5.76)$ \\
\hline \multirow[t]{2}{*}{ CONC } & -2.065 & $-19.49 * *$ & -6.164 & -9.477 & 3.827 & -1.202 & -11.66 \\
\hline & $(-0.29)$ & $(-2.01)$ & $(-0.67)$ & $(-1.33)$ & $(0.52)$ & $(-0.17)$ & $(-1.24)$ \\
\hline \multirow[t]{2}{*}{ GDP } & $0.228 * * *$ & $0.382 * * *$ & $0.349 * * *$ & $0.238 * * *$ & $0.235 * * *$ & $0.223 * * *$ & $0.367^{* * *}$ \\
\hline & (4.48) & (7.08) & (6.37) & (4.67) & (4.53) & $(4.37)$ & (6.97) \\
\hline \multirow[t]{2}{*}{ REG } & $-0.757 * * *$ & $-0.854 * * *$ & $-1.021^{* * *}$ & $-0.624 * * *$ & $-0.624^{* * *}$ & $-0.774 * * *$ & $-0.911 * * *$ \\
\hline & $(-3.44)$ & $(-3.82)$ & $(-4.10)$ & $(-2.80)$ & $(-2.73)$ & $(-3.51)$ & $(-4.01)$ \\
\hline SIZE & $-4.395 * * *$ & $-4.602 * * *$ & $-3.704 * * *$ & $-4.222 * * *$ & $-4.159 * * *$ & $-4.398 * * *$ & $-4.460 * * *$ \\
\hline
\end{tabular}




\begin{tabular}{|c|c|c|c|c|c|c|c|}
\hline & $(-6.86)$ & $(-6.21)$ & $(-5.56)$ & $(-6.78)$ & $(-6.60)$ & $(-6.93)$ & $(-6.18)$ \\
\hline \multirow[t]{2}{*}{ ROA } & $-0.756 * * *$ & $-1.092 * * *$ & $-0.946 * * *$ & $-0.630 * *$ & $-0.689 * *$ & $-0.734 * * *$ & $-0.842 * * *$ \\
\hline & $(-2.86)$ & $(-3.70)$ & $(-3.21)$ & $(-2.39)$ & $(-2.57)$ & $(-2.76)$ & $(-2.89)$ \\
\hline \multirow[t]{2}{*}{ ZSCORE } & 0.255 & 0.310 & 0.238 & 0.257 & 0.254 & 0.257 & 0.271 \\
\hline & $(1.26)$ & $(1.54)$ & $(1.17)$ & $(1.28)$ & $(1.24)$ & $(1.28)$ & $(1.38)$ \\
\hline \multirow[t]{2}{*}{ DEP_INS } & 8.619 & 7.963 & $17.63 * * *$ & $11.93^{* *}$ & 8.352 & 8.644 & $12.96 * *$ \\
\hline & $(1.45)$ & $(1.32)$ & $(2.96)$ & $(2.03)$ & $(1.42)$ & $(1.45)$ & (2.19) \\
\hline \multirow[t]{2}{*}{ Islamic } & 0.147 & -0.324 & -0.165 & 0.157 & 0.125 & 0.130 & -0.226 \\
\hline & $(0.08)$ & $(-0.18)$ & $(-0.10)$ & $(0.09)$ & $(0.07)$ & $(0.07)$ & $(-0.13)$ \\
\hline \multirow[t]{2}{*}{ Gov } & $4.004^{* *}$ & $3.864^{* *}$ & $3.497^{* *}$ & $4.068 * *$ & $3.787^{* *}$ & $4.024 * *$ & $3.728^{* *}$ \\
\hline & $(2.36)$ & $(2.25)$ & $(2.20)$ & $(2.44)$ & $(2.27)$ & $(2.37)$ & $(2.21)$ \\
\hline \multirow[t]{2}{*}{ Listed } & $4.233^{* *}$ & $3.858^{* *}$ & $3.396^{* *}$ & $4.036 * *$ & $4.081^{* *}$ & $4.225^{* *}$ & $3.835^{* *}$ \\
\hline & $(2.49)$ & $(2.22)$ & $(2.11)$ & (2.39) & $(2.42)$ & $(2.48)$ & $(2.23)$ \\
\hline \multirow[t]{2}{*}{ Constant } & $73.37^{* * *}$ & $84.72 * * *$ & $70.82 * * *$ & $52.85^{* * *}$ & $48.54 * * *$ & $71.23 * * *$ & $80.66 * * *$ \\
\hline & $(7.28)$ & $(7.53)$ & $(6.83)$ & $(5.26)$ & $(4.33)$ & (7.36) & $(7.28)$ \\
\hline Time fixed effects & YES & YES & YES & YES & YES & YES & YES \\
\hline Country fixed effects & YES & YES & YES & YES & YES & YES & YES \\
\hline Observations & 955 & 838 & 885 & 925 & 925 & 955 & 832 \\
\hline Groups & 146 & 144 & 145 & 143 & 143 & 146 & 141 \\
\hline
\end{tabular}

This table reports the main regression results of bank capital determinants and the effect of institutional variables using the Hausman-Taylor model for the period 2004-2014. The dependent variable is KBUFF, the capital buffer ratio. The independent variables are the following: PS is the measure of political stability. GC is a component of creditor's rights and measures the ease of getting credit. RI is another component of creditor's rights and it accounts for the ease of resolving insolvency, as well as liquidation. EF is the economic freedom index. FO is a measure of financial openness and includes financial and trade freedom. CPI is a corruption perception index. IFI is the institutional index we compute, it is the first principal component of PS, FO, EF, CPI. CRT is the creditor's rights index which is the principal component of two indexes: GC and RI. CONC is a measure of bank concentration calculated using the Herfindahl-Hirschman index on total assets. GDP measures the annual GDP Growth rate. REG is a score which measures the stringency of a country's capital regulatory jurisdiction. SIZE is calculated by the log of the total assets held by a bank. ROA is the return on average assets. ZSCORE is a measure of the risk of default. DEP_INS is a dummy which takes the value of 1 for an explicit deposit insurance system and 0 for an implicit deposit insurance scheme. Islamic, Gov, and Listed are dummy variables for Islamic banks, government-owned banks, and listed banks respectively. All the ratios are expressed in percentages. Size is the natural logarithm of total assets which is in thousand U.S Dollars. Reported beneath each coefficient estimate is the tstatistic adjusted for clustering at the bank level. *, ** and *** indicate statistical significance at the $10 \%, 5 \%$ and $1 \%$ levels, respectively. 
Table 3: The impact of institutional variables on bank capital - Robustness Check: General Method of Moments

Lag_TCR

Lag_EQTA

PS

GC

$\mathrm{RI}$

EF

FO

$\mathrm{CPI}$

II

CRT

ROA

ZSCORE

SIZE

CONC

GDP

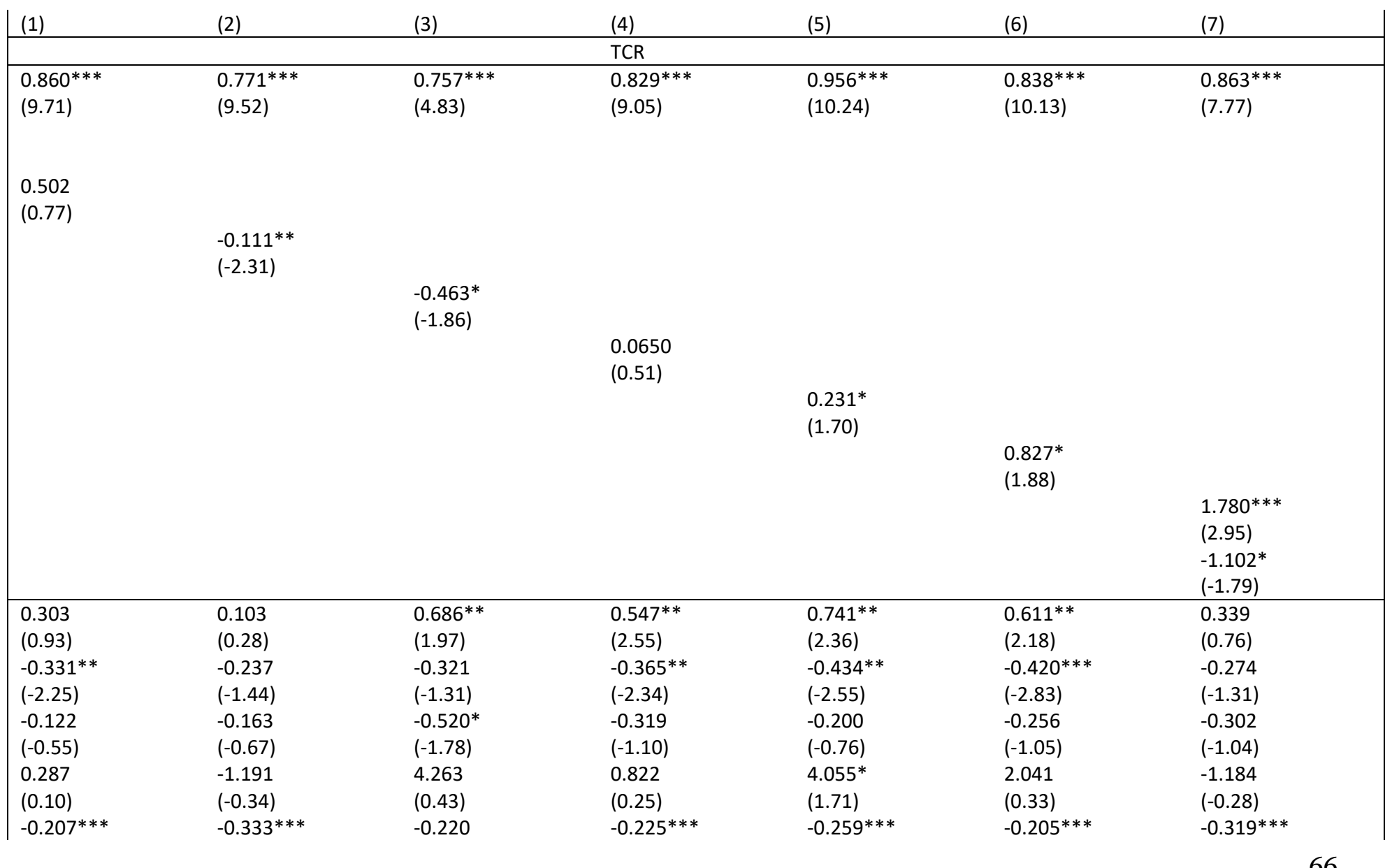




\begin{tabular}{|c|c|c|c|c|c|c|c|}
\hline & $(-4.38)$ & $(-6.38)$ & $(-1.28)$ & $(-4.55)$ & $(-4.20)$ & $(-4.29)$ & $(-5.36)$ \\
\hline \multirow[t]{2}{*}{ REG } & $0.278^{* * *}$ & $0.385^{* * *}$ & 0.434 & $0.278^{*}$ & $0.244^{* *}$ & $0.407^{*}$ & 0.00211 \\
\hline & (2.59) & $(3.22)$ & $(0.96)$ & (1.69) & $(2.15)$ & (1.69) & $(0.01)$ \\
\hline \multirow[t]{2}{*}{ DEP_INS } & 0.445 & $-2.255^{* *}$ & -0.0543 & 0.234 & -1.285 & 0.261 & 0.535 \\
\hline & $(1.41)$ & $(-1.97)$ & $(-0.04)$ & $(0.57)$ & $(-1.22)$ & $(0.32)$ & $(0.29)$ \\
\hline \multirow[t]{2}{*}{ Islamic } & -0.573 & $-1.139 *$ & -0.351 & -0.621 & $-0.943^{* *}$ & -0.440 & $-1.126 *$ \\
\hline & $(-0.97)$ & $(-1.88)$ & $(-0.64)$ & $(-1.62)$ & $(-2.20)$ & $(-0.91)$ & $(-1.67)$ \\
\hline \multirow[t]{2}{*}{ Gov } & -0.213 & -0.452 & 0.341 & -0.00541 & -0.201 & 0.195 & -0.523 \\
\hline & $(-0.37)$ & $(-0.84)$ & $(0.71)$ & $(-0.01)$ & $(-0.54)$ & $(0.37)$ & $(-0.73)$ \\
\hline \multirow[t]{2}{*}{ Listed } & -0.0349 & -0.115 & 0.0722 & 0.00563 & -0.447 & 0.260 & -0.668 \\
\hline & $(-0.08)$ & $(-0.26)$ & $(0.09)$ & $(0.01)$ & $(-0.99)$ & $(0.53)$ & $(-1.12)$ \\
\hline \multirow[t]{2}{*}{ Constant } & 4.798 & $13.83 * *$ & 13.62 & 3.855 & -10.98 & 7.100 & 8.379 \\
\hline & $(1.05)$ & $(2.38)$ & $(1.16)$ & $(0.72)$ & $(-1.10)$ & $(1.33)$ & $(1.45)$ \\
\hline Observations & 895 & 838 & 838 & 868 & 868 & 895 & 832 \\
\hline Groups & 145 & 144 & 144 & 142 & 142 & 145 & 141 \\
\hline AR1 p-stat & 0.0002 & 0.0004 & 0.0022 & 0.0006 & 0.0002 & 0.0006 & 0.0004 \\
\hline AR2 p-stat & 0.989 & 0.3943 & 0.2432 & 0.1123 & 0.0793 & 0.1109 & 0.2461 \\
\hline Hansen p-stat & 0.7405 & 0.4135 & 0.251 & 0.4482 & 0.780 & 0.8426 & 0.6299 \\
\hline
\end{tabular}


Table 3: The impact of institutional variables on bank capital - Robustness Check: General Method of Moments (Continued)

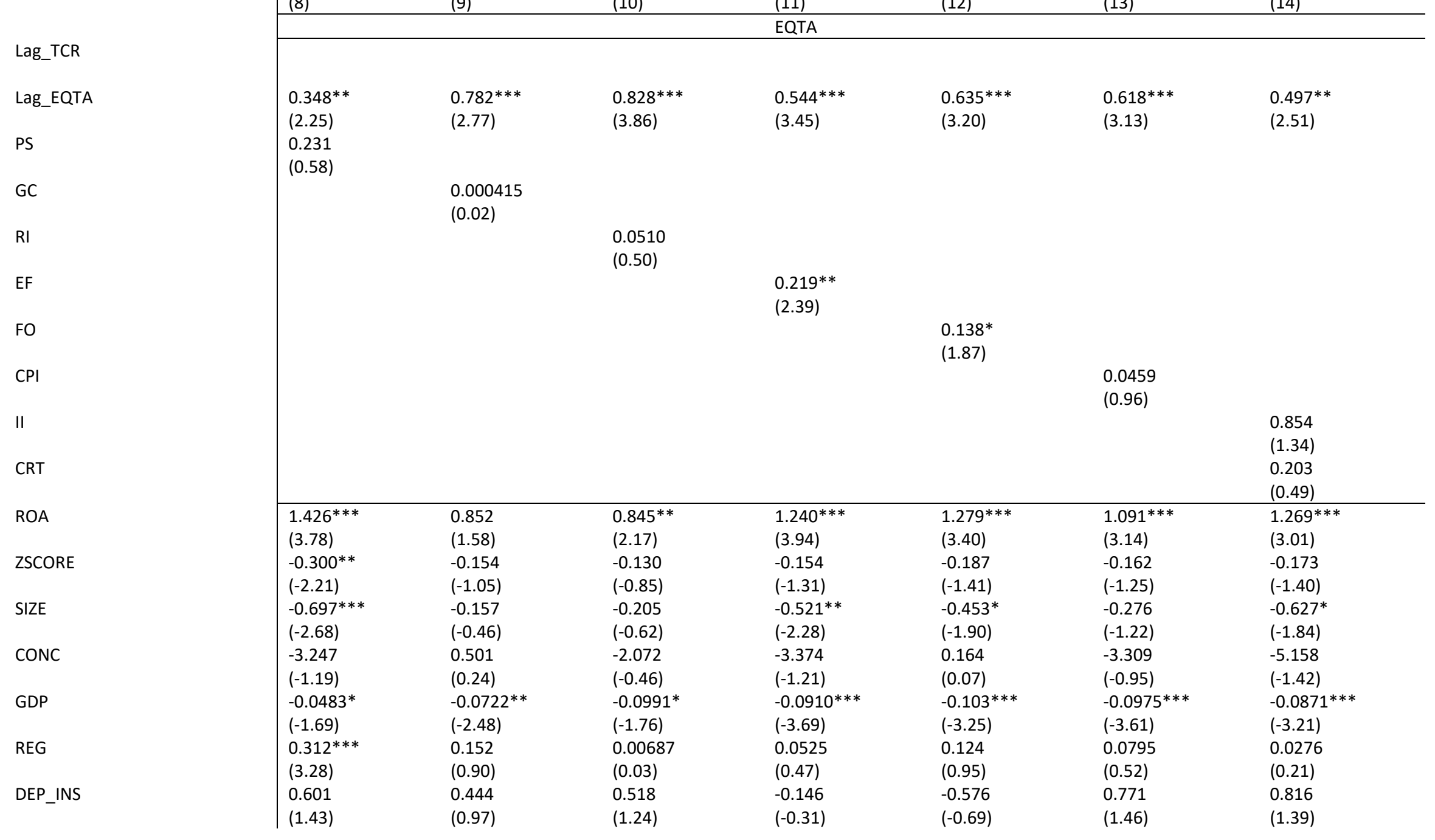




\begin{tabular}{|c|c|c|c|c|c|c|c|}
\hline Islamic & $\begin{array}{l}0.844 \\
(1.00)\end{array}$ & $\begin{array}{l}-0.230 \\
(-0.31)\end{array}$ & $\begin{array}{l}-0.205 \\
(-0.30)\end{array}$ & $\begin{array}{l}-0.412 \\
(-0.81)\end{array}$ & $\begin{array}{l}0.0808 \\
(0.14)\end{array}$ & $\begin{array}{l}-0.176 \\
(-0.31)\end{array}$ & $\begin{array}{l}0.129 \\
(0.18)\end{array}$ \\
\hline Gov & $\begin{array}{l}1.444^{*} \\
(1.83)\end{array}$ & $\begin{array}{l}0.356 \\
(0.38)\end{array}$ & $\begin{array}{l}0.493 \\
(0.49)\end{array}$ & $\begin{array}{l}0.351 \\
(0.50)\end{array}$ & $\begin{array}{l}0.644 \\
(0.92)\end{array}$ & $\begin{array}{l}0.505 \\
(0.70)\end{array}$ & $\begin{array}{l}0.820 \\
(0.97)\end{array}$ \\
\hline Listed & $\begin{array}{l}0.626 \\
(1.31)\end{array}$ & $\begin{array}{l}-0.0688 \\
(-0.11)\end{array}$ & $\begin{array}{l}0.0933 \\
(0.13)\end{array}$ & $\begin{array}{l}-0.241 \\
(-0.52)\end{array}$ & $\begin{array}{l}0.0197 \\
(0.04)\end{array}$ & $\begin{array}{l}-0.0719 \\
(-0.15)\end{array}$ & $\begin{array}{l}0.0661 \\
(0.14)\end{array}$ \\
\hline Constant & $\begin{array}{l}16.21^{* * *} \\
(3.33)\end{array}$ & $\begin{array}{l}3.815 \\
(0.53)\end{array}$ & $\begin{array}{l}2.779 \\
(0.51)\end{array}$ & $\begin{array}{l}-1.047 \\
(-0.19)\end{array}$ & $\begin{array}{l}0.878 \\
(0.13)\end{array}$ & $\begin{array}{l}5.708 \\
(1.28)\end{array}$ & $\begin{array}{l}14.32^{* *} \\
(2.13)\end{array}$ \\
\hline Observations & 953 & 894 & 894 & 926 & 926 & 953 & 888 \\
\hline Groups & 148 & 147 & 147 & 145 & 145 & 148 & 144 \\
\hline AR1 p-stat & 0.0489 & 0.0300 & 0.0035 & 0.0083 & 0.0164 & 0.0170 & 0.0135 \\
\hline AR2 p-stat & 0.8750 & 0.9214 & 0.9802 & 0.8697 & 0.9368 & 0.9974 & 0.6424 \\
\hline Hansen $p$-stat & 0.399 & 0.488 & 0.3183 & 0.5139 & 0.2592 & 0.2640 & 0.6354 \\
\hline
\end{tabular}

This table reports the main regression results of bank capital determinants and the effect of institutional variables using the general method of moments (GMM) with lagged dependent variables. The period of estimation is from year 2004 to 2014. The dependent variables are TCR; the total capital adequacy ratio (column 1 to 7 ) and EQTA; equity to total assets ratio (column 8 to 14). The independent variables are the following: Lag_TCR is the total capital adequacy ratio at t-1. Lag_EQTA is the equity to total assets ratio at t-1. PS is the measure of political stability. GC is a component of creditor's rights and measures the ease of getting credit. RI is another component of creditor's rights and it accounts for the ease of resolving insolvency, as well as liquidation. EF is the economic freedom index. FO is a measure of financial openness and includes financial and trade freedom. CPI is a corruption perception index. IFI is the institutional index we compute, it is the first principal component of PS, FO, EF, CPI. CRT is the creditor's rights index which is the principal component of two indexes: GC and RI. CONC is a measure of bank concentration calculated using the Herfindahl-Hirschman index on total assets. GDP measures the annual GDP Growth rate. REG is a score which measures the stringency of a country's capital regulatory jurisdiction. SIZE is calculated by the log of the total assets held by a bank. ROA is the return on average assets. ZSCORE is a measure of the risk of default. DEP_INS is a dummy which takes the value of 1 for an explicit deposit insurance system and 0 for an implicit deposit insurance scheme. Islamic, Gov, and Listed are dummy variables for Islamic banks, government-owned banks, and listed banks respectively. All the ratios are expressed in percentages. Size is the natural logarithm of total assets which is in thousand U.S Dollars. Reported beneath each coefficient estimate is the t-statistic adjusted for clustering at the bank level. *,** and *** indicate statistical significance at the $10 \%, 5 \%$ and $1 \%$ levels, respectively. 
Table 4: The impact of institutional variables on bank capital - Robustness Check: Countries excluding Malta, GCC, and Israel

\begin{tabular}{|c|c|c|c|c|c|c|c|c|c|c|c|c|c|c|}
\hline \multirow[b]{3}{*}{ PS } & (1) & (2) & (3) & (4) & (5) & (6) & (7) & (8) & (9) & (10) & (11) & (12) & (13) & (14) \\
\hline & TCR & & & & & & & EQTA & & & & & & \\
\hline & $\begin{array}{l}1.399^{*} \\
(1.88)\end{array}$ & & & & & & & $\begin{array}{l}0.668 \\
(1.53)\end{array}$ & & & & & & \\
\hline GC & & $\begin{array}{l}0.115^{* * *} \\
(-3.71)\end{array}$ & & & & & & & $\begin{array}{l}0.00725 \\
(0.66)\end{array}$ & & & & & \\
\hline $\mathrm{RI}$ & & & $\begin{array}{l}- \\
0.608 * * * \\
(-4.84)\end{array}$ & & & & & & & $\begin{array}{l}-0.00100 \\
(-0.02)\end{array}$ & & & & \\
\hline $\mathrm{EF}$ & & & & $\begin{array}{l}0.532 * * * \\
(3.27)\end{array}$ & & & & & & & $\begin{array}{l}- \\
0.192 * * * \\
(-3.30)\end{array}$ & & & \\
\hline FO & & & & & $\begin{array}{l}0.416^{* * *} \\
(6.54)\end{array}$ & & & & & & & $\begin{array}{l}-0.0195 \\
(-0.82)\end{array}$ & & \\
\hline CPI & & & & & & $\begin{array}{l}0.313^{* * *} \\
(2.94)\end{array}$ & & & & & & & $\begin{array}{l}-0.0607 \\
(-1.57)\end{array}$ & \\
\hline II & & & & & & & $\begin{array}{l}7.015^{* * *} \\
(4.03) \\
-\end{array}$ & & & & & & & $\begin{array}{l}-0.829 \\
(-1.31)\end{array}$ \\
\hline CRT & & & & & & & $\begin{array}{l}3.329 * * * \\
(-4.34)\end{array}$ & & & & & & & $\begin{array}{l}0.142 \\
(0.51) \\
\end{array}$ \\
\hline & - & & - & - & - & - & & & & & & & & \\
\hline CONC & $\begin{array}{l}140.3^{* * *} \\
(-6.26) \\
-\end{array}$ & $\begin{array}{l}-53.71 * \\
(-1.77)\end{array}$ & $\begin{array}{l}84.07 * * * \\
(-3.84) \\
-\end{array}$ & $\begin{array}{l}103.5^{* * *} \\
(-4.82) \\
-\end{array}$ & $\begin{array}{l}103.1^{* * *} \\
(-4.98) \\
-\end{array}$ & $\begin{array}{l}133.1^{* * *} \\
(-5.98)\end{array}$ & $\begin{array}{l}-29.16 \\
(-0.99)\end{array}$ & $\begin{array}{l}9.408 \\
(1.16)\end{array}$ & $\begin{array}{l}26.52^{* *} \\
(2.47)\end{array}$ & $\begin{array}{l}5.378 \\
(0.67)\end{array}$ & $\begin{array}{l}1.775 \\
(0.23)\end{array}$ & $\begin{array}{l}4.882 \\
(0.63)\end{array}$ & $\begin{array}{l}9.249 \\
(1.15)\end{array}$ & $\begin{array}{l}25.33^{* *} \\
(2.37)\end{array}$ \\
\hline GDP & $\begin{array}{l}0.389 * * * \\
(-3.12)\end{array}$ & $\begin{array}{l}-0.0358 \\
(-0.27)\end{array}$ & $\begin{array}{l}0.434^{* * *} \\
(-3.51) \\
-\end{array}$ & $\begin{array}{l}0.321^{* * *} \\
(-2.65)\end{array}$ & $\begin{array}{l}0.305^{* * *} \\
(-2.63)\end{array}$ & $\begin{array}{l}-0.198^{*} \\
(-1.65)\end{array}$ & $\begin{array}{l}-0.0486 \\
(-0.40) \\
-\end{array}$ & $\begin{array}{l}-0.0310 \\
(-0.69)\end{array}$ & $\begin{array}{l}-0.0607 \\
(-1.29)\end{array}$ & $\begin{array}{l}-0.0530 \\
(-1.17)\end{array}$ & $\begin{array}{l}-0.0261 \\
(-0.61)\end{array}$ & $\begin{array}{l}-0.0502 \\
(-1.16)\end{array}$ & $\begin{array}{l}-0.0627 \\
(-1.45)\end{array}$ & $\begin{array}{l}-0.0593 \\
(-1.34)\end{array}$ \\
\hline REG & $\begin{array}{l}0.763 \\
(1.53) \\
-\end{array}$ & $\begin{array}{l}0.164 \\
(0.35) \\
-\end{array}$ & $\begin{array}{l}2.852^{* * *} \\
(-3.83) \\
-\end{array}$ & $\begin{array}{l}-1.126^{*} \\
(-1.95) \\
-\end{array}$ & $\begin{array}{l}-0.359 \\
(-0.80) \\
-\end{array}$ & $\begin{array}{l}0.277 \\
(0.60) \\
-\end{array}$ & $\begin{array}{l}1.843 * * * \\
(-3.35) \\
-\end{array}$ & $\begin{array}{l}0.273 \\
(1.50) \\
-\end{array}$ & $\begin{array}{l}0.556^{* * *} \\
(3.32) \\
-\end{array}$ & $\begin{array}{l}0.374 \\
(1.34) \\
-\end{array}$ & $\begin{array}{l}0.809^{* * *} \\
(3.86) \\
-\end{array}$ & $\begin{array}{l}0.401 * * \\
(2.37) \\
-\end{array}$ & $\begin{array}{l}0.335^{* *} \\
(1.97) \\
-\end{array}$ & $\begin{array}{l}0.726^{* * *} \\
(3.57) \\
-\end{array}$ \\
\hline SIZE & $\begin{array}{l}3.422 * * * \\
(-4.29)\end{array}$ & $\begin{array}{l}4.335^{* * *} \\
(-5.04)\end{array}$ & $\begin{array}{l}3.055^{* * *} \\
(-3.90)\end{array}$ & $\begin{array}{l}3.351 * * * \\
(-4.20)\end{array}$ & $\begin{array}{l}2.930 * * * \\
(-3.87)\end{array}$ & $\begin{array}{l}3.697 * * * \\
(-4.53)\end{array}$ & $\begin{array}{l}3.621^{* * *} \\
(-4.48)\end{array}$ & $\begin{array}{l}4.025 * * * \\
(-10.53)\end{array}$ & $\begin{array}{l}4.203 * * * \\
(-10.85)\end{array}$ & $\begin{array}{l}3.928 * * * \\
(-10.22)\end{array}$ & $\begin{array}{l}4.195 * * * \\
(-10.96)\end{array}$ & $\begin{array}{l}3.999 * * * \\
(-10.38)\end{array}$ & $\begin{array}{l}3.940 * * * \\
(-10.42)\end{array}$ & $\begin{array}{l}4.292^{* * *} \\
(-10.94)\end{array}$ \\
\hline ROA & $-1.225^{* *}$ & $-1.153^{* *}$ & $-0.861^{*}$ & $-1.207^{* *}$ & $-1.144^{* *}$ & - & $-0.883^{*}$ & $1.071^{* * *}$ & $1.280^{* * *}$ & $1.098^{* * *}$ & $1.029^{* * *}$ & $1.086 * * *$ & $1.122^{* * *}$ & $1.277^{* * *}$ \\
\hline
\end{tabular}




\begin{tabular}{|c|c|c|c|c|c|c|c|c|c|c|c|c|c|c|}
\hline & $(-2.50)$ & $(-2.22)$ & $(-1.74)$ & $(-2.45)$ & $(-2.40)$ & $\begin{array}{l}1.534 * * * \\
(-3.13)\end{array}$ & $(-1.72)$ & (5.98) & (6.90) & $(6.00)$ & $(5.80)$ & (6.07) & (6.27) & $(6.82)$ \\
\hline ZSCORE & $\begin{array}{l}0.306 \\
(1.10)\end{array}$ & $\begin{array}{l}0.198 \\
(0.69)\end{array}$ & $\begin{array}{l}0.246 \\
(0.89)\end{array}$ & $\begin{array}{l}0.283 \\
(1.01)\end{array}$ & $\begin{array}{l}0.366 \\
(1.34)\end{array}$ & $\begin{array}{l}0.319 \\
(1.14)\end{array}$ & $\begin{array}{l}0.294 \\
(1.05)\end{array}$ & $\begin{array}{l}-0.0303 \\
(-0.30)\end{array}$ & $\begin{array}{l}0.0446 \\
(0.44)\end{array}$ & $\begin{array}{l}-0.0221 \\
(-0.22)\end{array}$ & $\begin{array}{l}-0.0335 \\
(-0.34)\end{array}$ & $\begin{array}{l}-0.0276 \\
(-0.27)\end{array}$ & $\begin{array}{l}-0.0363 \\
(-0.36)\end{array}$ & $\begin{array}{l}0.0296 \\
(0.29)\end{array}$ \\
\hline Islamic & $\begin{array}{l}2.440 \\
(0.69)\end{array}$ & $\begin{array}{l}2.329 \\
(0.60)\end{array}$ & $\begin{array}{l}2.700 \\
(0.79)\end{array}$ & $\begin{array}{l}2.440 \\
(0.70)\end{array}$ & $\begin{array}{l}2.576 \\
(0.79)\end{array}$ & $\begin{array}{l}2.260 \\
(0.61)\end{array}$ & $\begin{array}{l}2.682 \\
(0.78)\end{array}$ & $\begin{array}{l}-3.433 \\
(-1.14)\end{array}$ & $\begin{array}{l}-3.296 \\
(-1.09)\end{array}$ & $\begin{array}{l}-3.380 \\
(-1.14)\end{array}$ & $\begin{array}{l}-3.507 \\
(-1.13)\end{array}$ & $\begin{array}{l}-3.412 \\
(-1.14)\end{array}$ & $\begin{array}{l}-3.380 \\
(-1.14)\end{array}$ & $\begin{array}{l}-3.337 \\
(-1.08)\end{array}$ \\
\hline Gov & $\begin{array}{l}6.040^{*} \\
(1.73)\end{array}$ & $\begin{array}{l}6.882^{*} \\
(1.81)\end{array}$ & $\begin{array}{l}5.426 \\
(1.62)\end{array}$ & $\begin{array}{l}5.875^{*} \\
(1.70)\end{array}$ & $\begin{array}{l}5.641^{*} \\
(1.76)\end{array}$ & $\begin{array}{l}6.464^{*} \\
(1.76)\end{array}$ & $\begin{array}{l}6.082^{*} \\
(1.79)\end{array}$ & $\begin{array}{l}8.779 * * * \\
(3.05)\end{array}$ & $\begin{array}{l}8.723 * * * \\
(3.03)\end{array}$ & $\begin{array}{l}8.691^{* * *} \\
(3.06)\end{array}$ & $\begin{array}{l}9.006^{* * *} \\
(3.03)\end{array}$ & $\begin{array}{l}8.744^{* * *} \\
(3.05)\end{array}$ & $\begin{array}{l}8.701^{* * *} \\
(3.07)\end{array}$ & $\begin{array}{l}8.864^{* * *} \\
(3.01)\end{array}$ \\
\hline Listed & $\begin{array}{l}5.687^{* *} \\
(2.15)\end{array}$ & $\begin{array}{l}6.515^{* *} \\
(2.26)\end{array}$ & $\begin{array}{l}5.319 * * \\
(2.10)\end{array}$ & $\begin{array}{l}5.573 * * \\
(2.13)\end{array}$ & $\begin{array}{l}5.050^{* *} \\
(2.08)\end{array}$ & $\begin{array}{l}6.083^{* *} \\
(2.19)\end{array}$ & $\begin{array}{l}5.757^{* *} \\
(2.24)\end{array}$ & $\begin{array}{l}4.107^{*} \\
(1.85)\end{array}$ & $\begin{array}{l}3.955^{*} \\
(1.78)\end{array}$ & $\begin{array}{l}4.049 * \\
(1.85)\end{array}$ & $\begin{array}{l}4.274 * \\
(1.87)\end{array}$ & $\begin{array}{l}4.089 * \\
(1.85)\end{array}$ & $\begin{array}{l}4.066^{*} \\
(1.86)\end{array}$ & $\begin{array}{l}4.088^{*} \\
(1.80)\end{array}$ \\
\hline Constant & $\begin{array}{l}78.66 * * * \\
(6.19)\end{array}$ & $\begin{array}{l}90.57^{* * *} \\
(6.61)\end{array}$ & $\begin{array}{l}92.99 * * * \\
(7.59)\end{array}$ & $\begin{array}{l}49.51^{* * *} \\
(3.05)\end{array}$ & $\begin{array}{l}54.63^{* * *} \\
(4.35)\end{array}$ & $\begin{array}{l}77.78^{* * *} \\
(5.94)\end{array}$ & $\begin{array}{l}82.70^{* * *} \\
(6.38)\end{array}$ & $\begin{array}{l}55.59^{* * *} \\
(7.10)\end{array}$ & $\begin{array}{l}54.71 * * * \\
(6.97)\end{array}$ & $\begin{array}{l}\text { 64.39*** } \\
(10.47)\end{array}$ & $\begin{array}{l}68.20^{* * *} \\
(7.65)\end{array}$ & $\begin{array}{l}55.96 * * * \\
(6.97)\end{array}$ & $\begin{array}{l}66.14 * * * \\
(10.62)\end{array}$ & $\begin{array}{l}65.40^{* * *} \\
(10.20)\end{array}$ \\
\hline $\begin{array}{l}\text { Time fixed } \\
\text { effects } \\
\text { Country }\end{array}$ & YES & YES & YES & YES & YES & YES & YES & YES & YES & YES & YES & YES & YES & YES \\
\hline fixed effects & YES & YES & YES & YES & YES & YES & YES & YES & YES & YES & YES & YES & YES & YES \\
\hline Observations & 483 & 459 & 483 & 483 & 483 & 483 & 459 & 483 & 459 & 483 & 483 & 483 & 483 & 459 \\
\hline Groups & 73 & 72 & 73 & 73 & 73 & 73 & 72 & 73 & 72 & 73 & 73 & 73 & 73 & 72 \\
\hline
\end{tabular}

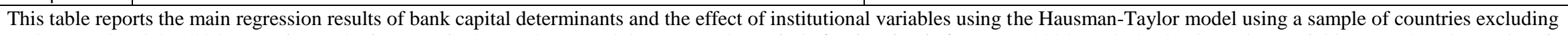

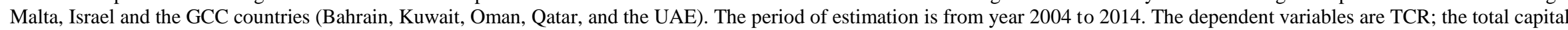
adequacy ratio (column 1 to 7) and EQTA; equity to total assets ratio (column 8 to 14). The independent variables are the following: PS is the measure of political stability. GC is a component of creditor's rights and measures the ease of getting credit. RI is another component of creditor's rights and it accounts for the ease of resolving insolvency, as well as

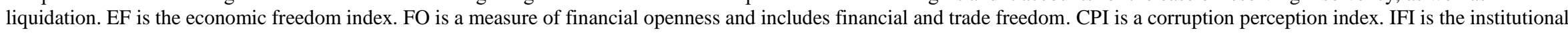
index we compute, it is the first principal component of PS, FO, EF, CPI. CRT is the creditor's rights index which is the principal component of two indexes: GC and RI. CONC is a

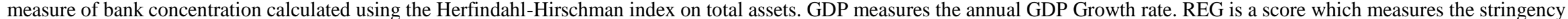
of a country's capital regulatory jurisdiction. SIZE is calculated by the log of the total assets held by a bank. ROA is the return on average assets. ZSCORE is a measure of the risk of default. DEP_INS is a dummy which takes the value of 1 for an explicit deposit insurance system and 0 for an implicit deposit insurance scheme. Islamic, Gov, and Listed are dummy variables for Islamic banks, government-owned banks, and listed banks respectively. All the ratios are expressed in percentages. Size is the natural logarithm of total assets which is in

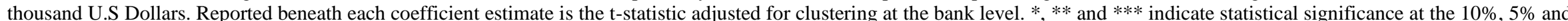
$1 \%$ levels, respectively. 